\title{
WestVirginiaUniversity
}

THE RESEARCH REPOSITORY @ WVU

Graduate Theses, Dissertations, and Problem Reports

2020

\section{An Examination to Pathways Powering Car Using Clean Energy}

Marina Miranda

West Virginia University, mm0282@mix.wvu.edu

Follow this and additional works at: https://researchrepository.wvu.edu/etd

Part of the Automotive Engineering Commons, Energy Systems Commons, and the Power and Energy Commons

\section{Recommended Citation}

Miranda, Marina, "An Examination to Pathways Powering Car Using Clean Energy" (2020). Graduate Theses, Dissertations, and Problem Reports. 7713.

https://researchrepository.wvu.edu/etd/7713

This Problem/Project Report is protected by copyright and/or related rights. It has been brought to you by the The Research Repository @WVU with permission from the rights-holder(s). You are free to use this Problem/Project Report in any way that is permitted by the copyright and related rights legislation that applies to your use. For other uses you must obtain permission from the rights-holder(s) directly, unless additional rights are indicated by a Creative Commons license in the record and/ or on the work itself. This Problem/Project Report has been accepted for inclusion in WVU Graduate Theses, Dissertations, and Problem Reports collection by an authorized administrator of The Research Repository @ WVU. For more information, please contact researchrepository@mail.wvu.edu. 


\title{
An Examination to Pathways Powering Car Using Clean Energy
}

\author{
Marina Miranda \\ Project Report Submitted to the \\ Benjamin M. Statler College of Engineering and Mineral Resources \\ West Virginia University \\ In partial fulfillment of the requirements for the degree of \\ Master of Science in \\ Energy Systems Engineering \\ Hailin Li, Ph.D., Chair \\ Roger Chen, Ph.D. \\ Yi Luo, Ph.D. \\ Department of Aerospace and Mechanical Engineering \\ Morgantown, West Virginia
}

2020

Keywords: Wind Energy, Energy Consumption, Battery Electric Vehicle, Fuel Cell Electric Vehicle, Compressed Hydrogen, Liquid Hydrogen

Copyright @ 2020 Marina Miranda 


\title{
ABSTRACT \\ An Examination to Pathways Powering Car Using Clean Energy
}

\author{
Marina Miranda
}

Traditional vehicles powered by internal combustion engines contribute significantly to increasing emissions of greenhouses gasses (GHG). There has been increasing interest in powering vehicles using green energy include using electricity produced by wind turbine and solar panel. The green electricity can be used to directly charge the Battery Electric Vehicles (BEV), or producing hydrogen as fuel for Fuel Cell Electric Vehicles (FCEV) by converting electrical energy to hydrogen $\left(\mathrm{H}_{2}\right)$ through water electrolysis. The low energy density $\mathrm{H}_{2}$ produced can be stored on board as either compressed $\mathrm{H}_{2}$ or liquefied $\mathrm{H}_{2}$.

This research examines the energy consumption and system efficiency from electricity produced by wind power to charge a car battery or filled to hydrogen tank of FCEV using vehicle operation mileage as reference. The distance specific consumption of wind turbine energy is investigated. The energy consumption of $\mathrm{H}_{2}$ production, compression, liquefaction, and pre-chilling are accounted for and converted to electricity on a per $\mathrm{kg} \mathrm{H}_{2}$ fuel basis. The efficiency of a fuel cell, battery charging, discharging, and motor, derived from literature review, are accounted for and used to calculate electricity consumed. Over 100 miles, the average wind turbine energy consumed by BEV, FCEV with compressed, and liquid hydrogen was $43.6 \mathrm{kWh}$, $87.2 \mathrm{kWh}$, and $111.18 \mathrm{kWh}$, respectively at a combined city and highway setting. This research shows that the BEV pathway is more energy efficient than the FCEV pathway. This conclusion is derived only on the basis of energy consumption without taking into account the cost of the system. The literature data also shows that fuel cell system is much more expensive than the battery system. 


\section{$\underline{\text { Acknowledgement }}$}

First and foremost, I would like to thank Dr. Hailin Li, my Academic Advisor for not only believing in me, but also for introducing me to the World of cars and inspiring me in completing this research and show so much kindness and patience during challenging moments in putting this thesis together. I would also like to thank Dr. Roger Chen, Dr. Yi Luo, members of the advising Committee for believing in me. I would also like to thank Amgad Elowainy for being so kind in providing data on hydrogen refueling from compression to liquefying and also for allowing me to have access to the hydrogen model from the Argonne National Laboratory. I also owe so much gratitude to David Friend, from Laurel Renewable for being so kind in supplying me with data on a wind farm from West Virginia.

I am forever grateful to my family for being so supportive of me and kept me going especially during challenging moments. 


\section{$\underline{\text { Table of Contents }}$}

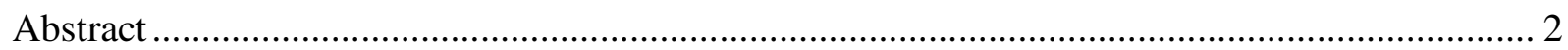

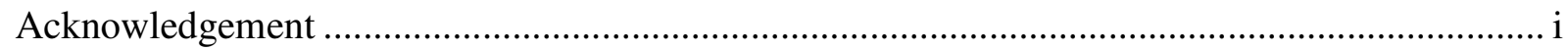

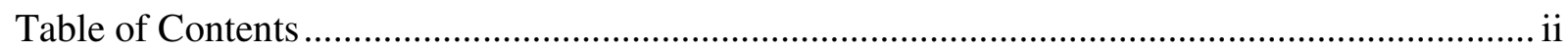

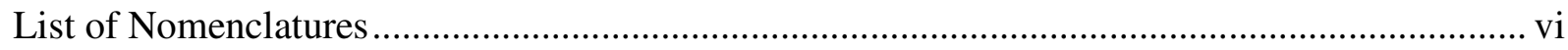

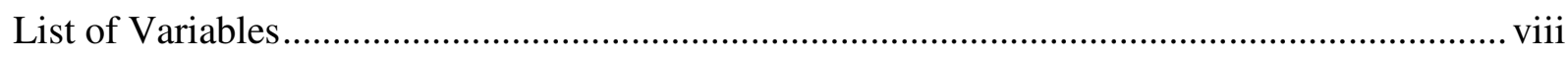

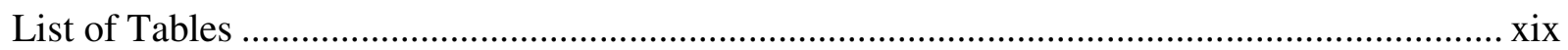

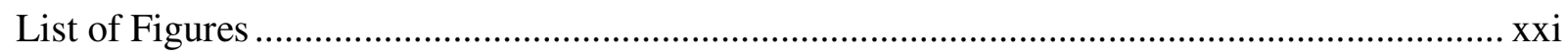

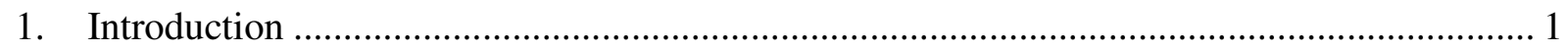

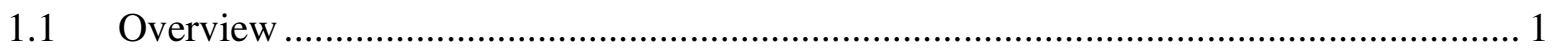

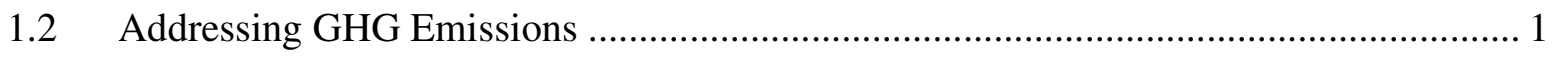

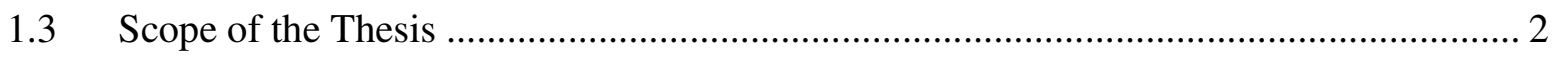

2. Literature Review-Renewable Electricity Production ..................................................... 5

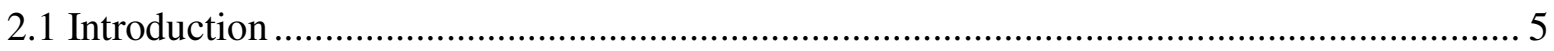

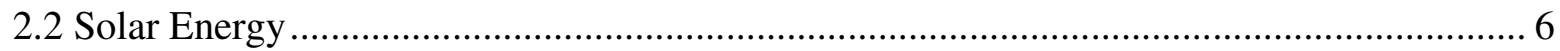

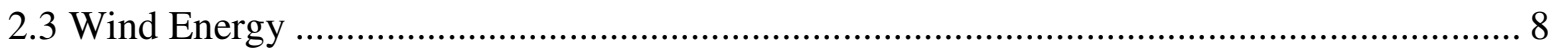

2.4 Battery Electric Vehicles and Plug-in Hybrid Electric Vehicles .................................... 12

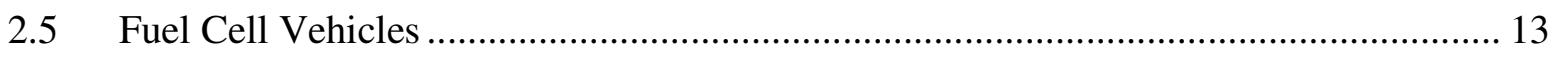

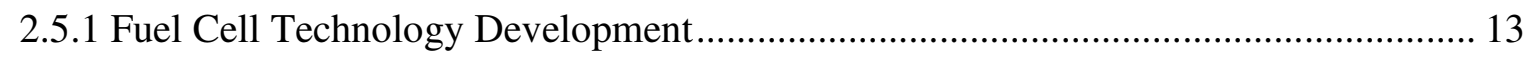

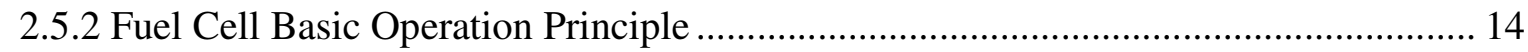


3. Wind Energy Production and Its Application in Driving Car

3.1 Powering Vehicles with Wind Energy …................................................................ 19

3.2 Scenarios 1 and 2: Power Generated by Wind ........................................................... 19

3.2.1 Local Geographical Aspects of Wind ................................................................... 19

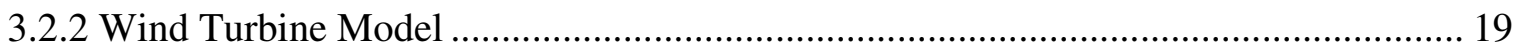

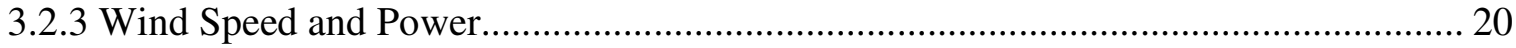

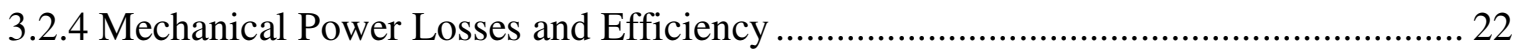

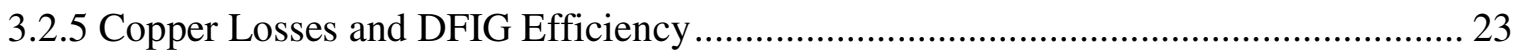

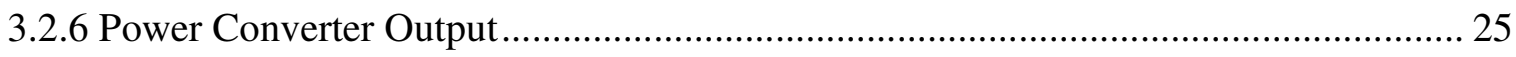

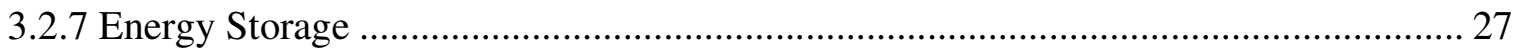

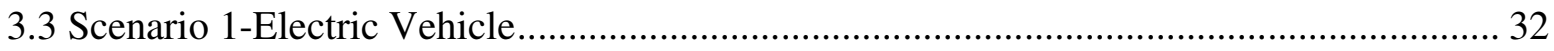

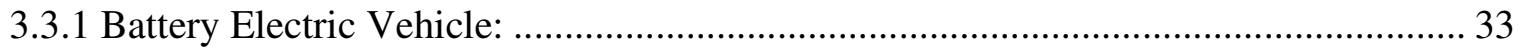

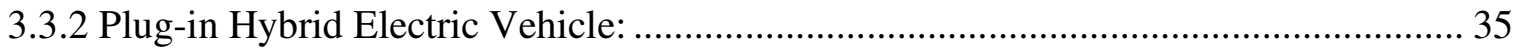

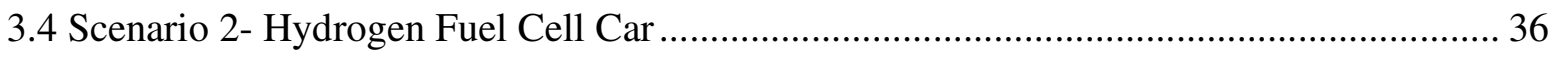

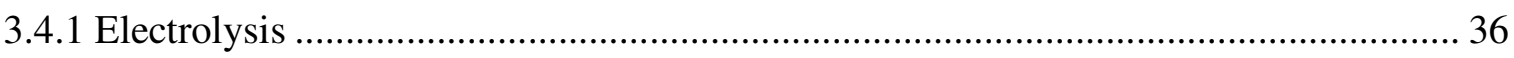

3.4.2 Liquid Hydrogen Production and Efficiency............................................................... 41

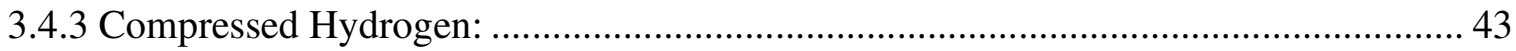

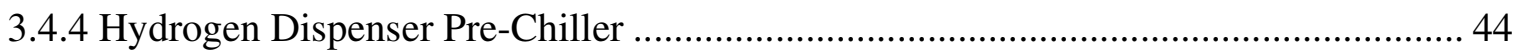


3.5 Identify the most attractive

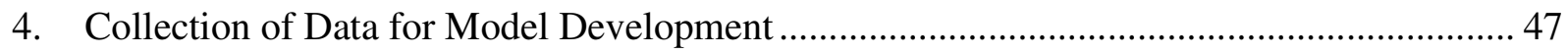

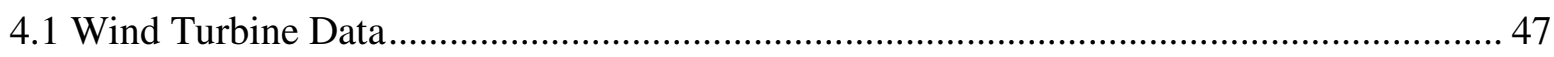

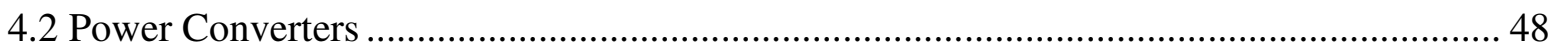

4.3 Scenario 1: Charging Cars Directly from the Community Giant Battery …....................... 50

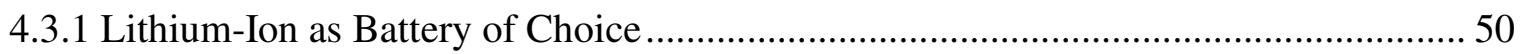

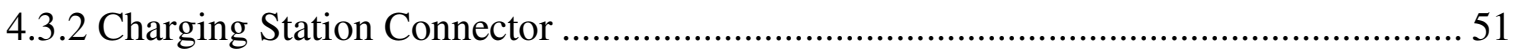

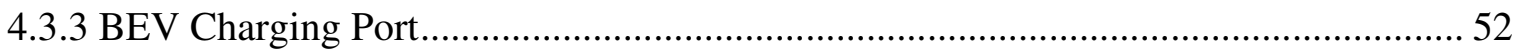

4.3.4 Buck Converter Between Battery and Charging Port.............................................. 53

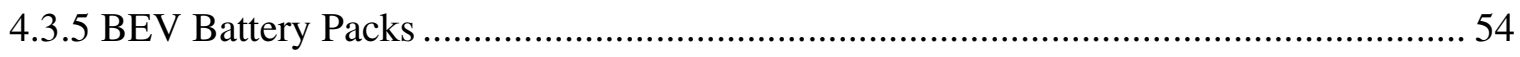

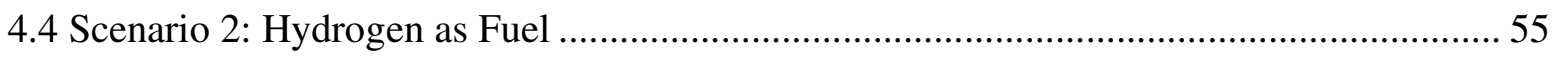

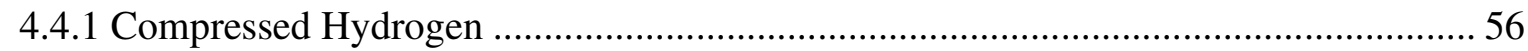

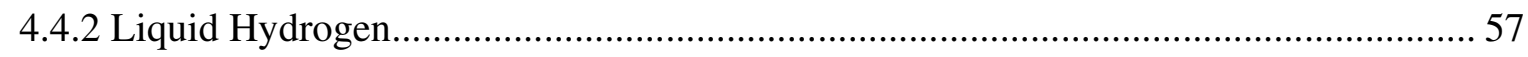

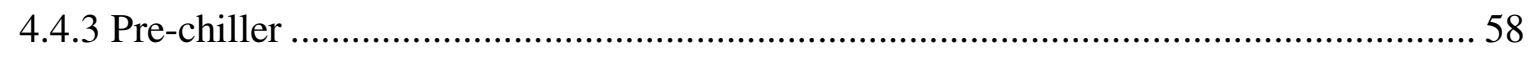

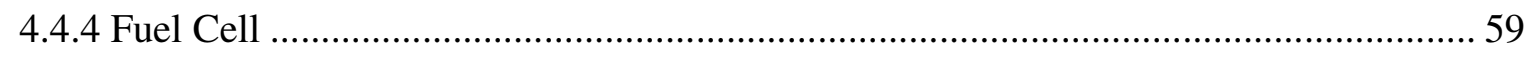

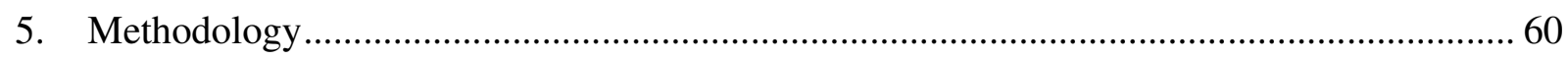

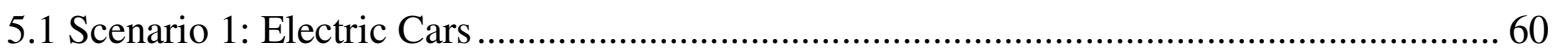

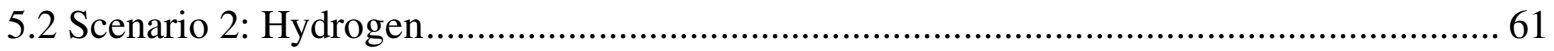

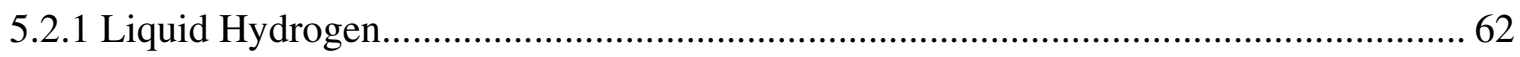




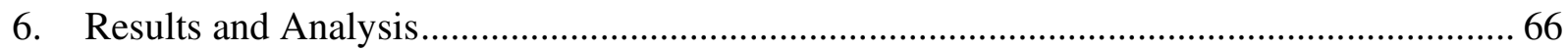

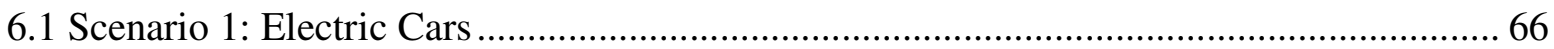

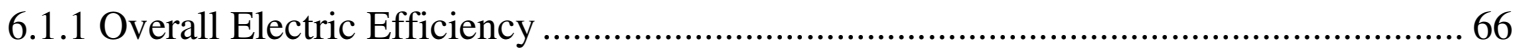

6.1.2 Pre-charge, range available, charging time, and energy consumption ......................... 66

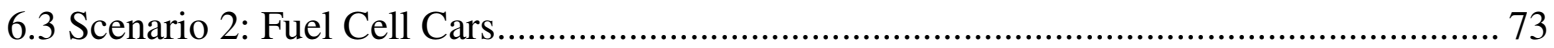

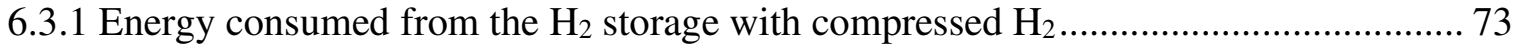

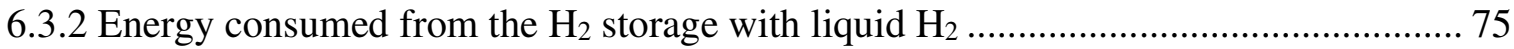

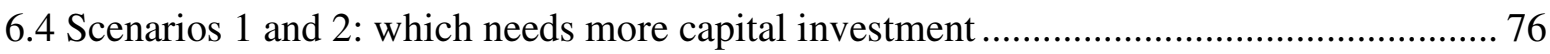

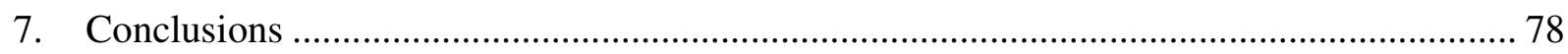

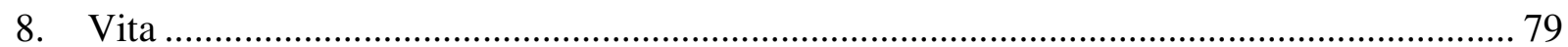

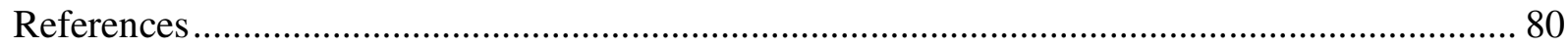




\section{List of Nomenclatures}

ACDC: Alternating current to direct current

AC: Alternating Current

BTU: British Thermal Units

CAA: Clean Air Act

COP: Chiller coefficient of performance

Cut-In Wind Speed: minimum speed required for wind turbine to generate power

Cut-Out Wind Speed: maximum wind speed at which wind turbine generates power

DC: Direct Current

DFIG: Dual feed induction generator

DOT: Department of Transportation

EISA: Energy Independence and Security Act

EMF: Electro-motive force of the cell

EPA: Environmental Protection Agency

EPAct: Energy Policy Act of 2005

FWD: Forward converter that uses a transformer to increase or decrease the output voltage

IC: Internal Combustion

ICEV: Internal Combustion Engine Vehicles 
IGBT: Insulated-gate bipolar transistor

$\mathrm{Nm}^{3}$ : Normal cubic meter of fluid a $0^{\circ} \mathrm{C}$ or $273.15 \mathrm{~K}$ and atmospheric pressure.

PHEV: Plug-in hybrid electric vehicles

Rated Wind Speed: wind speed at nominal DFIG mechanical input power

Redox: Ratio of reduction over oxide

RFS: Renewable Fuel Standard

RPM: Revolutions per minute

SOC: State of charge of the battery

ZEV: Zero-emission vehicles 


\section{$\underline{\text { List of Variables }}$}

$C O P_{\text {chiller }}:$ hydrogen dispenser chiller coefficient of performance

$C_{p}(\lambda, \beta)$ : wind turbine power coefficient as a function of tip speed ratio and blade tip angle

$D_{\text {rotor }}:$ diameter of the wind turbine rotor in $\mathrm{m}$

$d_{H_{2}}$ : distance in which a FCEV run with the consumption of a $\mathrm{kg}$ of hydrogen in miles

$E(T)$ : fuel cell voltage as a function of temperature in $\mathrm{V}$

$E_{\text {Act }}:$ activation overpotential in $\mathrm{V}$

$E^{A n o d \sigma}$ : potential at the anode relative to the reference electrode in $\mathrm{V}$

$E^{\text {Cathode }}$ : potential at the cathode relative to the reference electrode in $\mathrm{V}$

$E_{\text {Cone }}:$ concentration over potential in $\mathrm{V}$

$E_{\text {consumption }}$ : energy density consumed by electrolysis in $\mathrm{kWh} / \mathrm{m}^{3}$

$E_{\text {emf }}^{0}:$ standard emf of the cell in $\mathrm{V}$

$E_{\text {amf }}:$ emf of the cell in $\mathrm{V}$

$\dot{E}_{\text {fusl cenl in }}:$ hydrogen fuel cell energy input in W

$\Delta e_{\text {idealised }}:$ exergy differential between the feed and the product in $\mathrm{kWh} / \mathrm{kg}$ 
$E_{\text {cooling load }}$ : hydrogen dispenser specific cooling load in $\mathrm{kWh} / \mathrm{kg}$

$E_{\text {chiller }}:$ hydrogen chiller fuel specific energy consumption in $\mathrm{kWh} / \mathrm{kg}$

$E_{\text {DFE kWh par } 100 \text { milas }}$ : energy from the DFIG consumed by an electric vehicle over 100 miles in

$\mathrm{kWh}$

$E_{100 \text { milss }}$ : energy consumed by a BEV over 100 miles

$E_{\text {compressor input }}:$ hydrogen compressor input in $\mathrm{kWh} / \mathrm{kg}$

$E_{\text {electrolysis }}$ : specific energy output by the electrolyser when producing hydrogen in $\mathrm{kWh} / \mathrm{kg}$

$E_{\text {fuel cent }}: \mathrm{H}_{2}$ FCEV specific energy output in $\mathrm{kWh} / \mathrm{kg}$

$E_{\text {full charge }}:$ BEV battery energy at full capacity in kWh

$E_{\text {GH2 FCEV }}$ : total amount of energy consumed from the hydrogen storage if the hydrogen

consumed is stored in its gaseous form in $\mathrm{kWh}$

$E_{G H_{2} \text { inpat }}:$ compressed hydrogen total specific energy in $\mathrm{kWh} / \mathrm{kg}$

$E_{L H_{2}}$ input $:$ liquid hydrogen total specific energy in $\mathrm{kWh} / \mathrm{kg}$

$E_{L H 2 F C E V}$ : total amount of energy consumed from the hydrogen storage if the hydrogen consumed is stored in its gaseous form in $\mathrm{kWh}$

$E_{L H_{2} \text { pump }}$ : liquid hydrogen total specific energy in $\mathrm{kWh} / \mathrm{kg}$ 
$E_{\text {losses }}$ : total voltage potential loss in V

$E_{\text {liquefier }}:$ liquefier specific energy consumed in $\mathrm{kWh} / \mathrm{kg}$

$E_{\text {off }}:$ IGBT power converter switch off energy in $\mathrm{mJ} / \mathrm{pulse}$

$E_{\text {on }}:$ IGBT power converter switch on energy in $\mathrm{mJ} /$ pulse

$E_{\text {overall electrio }}$ : energy consumed by the BEV over 100 miles in percent

$E_{\text {Pre-charge }}:$ BEV battery energy at full capacity in percent

$E_{r r}:$ FWD power recovery switching energy in $\mathrm{mJ} /$ pulse

$E_{T N}(T):$ thermoneutral fuel cell voltage as a function of temperature in $\mathrm{V}$

F: faraday constant, 96485 coulombs per mole

$f_{s}$; stator frequency in $\mathrm{Hz}$

$f_{s w}:$ IGBT switching frequency in $\mathrm{Hz}$

$\Delta G^{\mathrm{D}}$ : standard Change in Gibbs-free energy as a function of temperature $\mathrm{T}$ in $\mathrm{kJ} / \mathrm{mol}$

$\Delta G(T)$ : change in Gibbs-free energy as a function of temperature $\mathrm{T}$ in $\mathrm{kJ} / \mathrm{mol}$

$\Delta H(T)$ : change in enthalpy as a function of temperature $\mathrm{T}$ in $\mathrm{kJ} / \mathrm{mol}$

$h_{f w \in l c \in l}:$ hydrogen fuel cell specific enthalpy in $\mathrm{kWh} / \mathrm{kg}$ 
$\mathbf{h}_{\text {iwput }}:$ enthalpy input in $\mathrm{kJ} / \mathrm{kg}$

$\mathbf{h}_{\text {output }}$ enthalpy output in $\mathrm{kJ} / \mathrm{kg}$

$H H V_{H_{a}}$ : hydrogen high heating value in $\mathrm{kWh} / \mathrm{m}^{3}$ or $\mathrm{kWh} / \mathrm{kg}$

$i$ : current density in $\mathrm{A} / \mathrm{cm}^{2}$

$I_{C}:$ IGBT collector nominal current in A

$I_{c e n}:$ current passing through the cell in A

$I_{c \in l l c h}$ : cell charging current capacity in A

$I_{\text {cen dis }}:$ cell discharge current capacity in A

$I_{E}:$ electrolysis current in A

$I_{\text {port }}$ : fast charging station port input current in A

$I_{r}:$ DFIG rotor side current in A

$I_{z}:$ DFIG stator side current in A

k: ratio of the thermal coefficient at constant pressure over the thermal coefficient at constant volume

$k_{g}$ : electrochemical equivalent in $\mathrm{kg} / \mathrm{C} \equiv \mathrm{kg} /(\mathrm{A} \cdot \mathrm{s})$

$m$ : number of moles or reactant required for complete cell discharge in mol 
$m_{\text {electrolysis }}$ : hydrogen mass produced by electrolysis in $\mathrm{kg}$

$m_{H_{2}}:$ liquid hydrogen production plant capacity in tons/day

$M_{H_{2}}:$ hydrogen molar mass in $\mathrm{g} / \mathrm{mol}$

$m_{H 2 \text { FCEV }}$ : hydrogen mass consumed by FCEV in $\mathrm{kg}$

$\mathrm{d}$ : specific distance in which one kilogram of hydrogen gas is consumed in miles.

$\mathrm{n}$ : Number of electrons being transferred between cathode and anode in mol

$n_{\text {cells }}:$ number of lithium-ion battery cells onsite

$n_{c e l l s}$ in parallel $:$ number of lithium-ion battery cells in parallel required to match the rectifier

output current over twenty-four hours

$n_{\text {cells in series }}:$ number of lithium-ion battery cells in series required to match the rectifier output

voltage

$n_{\text {stages }}:$ number of stages in the compressor

$n_{r}:$ generator rotor speed in rpm

$n_{\mathrm{w} t}:$ wind turbine speed in rpm

P: number of pole pairs

$P_{\text {atm }}:$ atmospheric pressure, $101325 \mathrm{~Pa}$. 
$P_{\text {cond }}$ IGBT power conduction losses in Watts

$P_{\text {diss }}:$ total IGBT and FWD power losses in W

$P_{\text {discharge }}:$ liquid hydrogen discharge pressure in $\mathrm{Pa}$

$P_{\text {inlet }}:$ hydrogen compressor inlet pressure in $\mathrm{Pa}$

$P_{\text {mach }}:$ mechanical input power in $\mathrm{W}$

$P_{\text {mech }}$ rotor $:$ rotor side mechanical input power in $\mathrm{W}$

$P_{\text {mech,stator }}$ stator side mechanical input power in W

$P_{\text {outlet }}:$ hydrogen compressor outlet pressure in $\mathrm{Pa}$

$P_{\text {output port }}$ : fast charging station port output power in $\mathrm{kW}$

$P_{\text {rated }}:$ rated turbine input power in $\mathrm{W}$

$P_{\text {rect output: }}$ IGBT rectifier output power in W

$P_{\text {rotor: }}$ rotor side electrical output power in W

$P_{r r}:$ FWD power losses in $\mathrm{W}$

$P_{\text {stator }}$ : stator side electrical output power in W

$P_{\text {suction }}:$ liquid hydrogen suction pressure in $\mathrm{Pa}$ 
$P_{s w}$ : IGBT switching power losses in Watts

$P_{\text {turbine }}:$ power generated by wind turbine in $\mathrm{W}$

$P_{\text {wind }}$ : power generated by the wind in $\mathrm{W}$

$q$ : the number of steps in the gear box

$Q_{c e n}:$ cell capacity in coulombs

$Q_{\text {cell ch }}:$ cell charging capacity in coulombs

$Q_{\text {cell dis }}$ : cell discharge capacity in coulombs

$Q_{R}$ : reaction quotient

$Q_{T}:$ theoretical cell capacity in amps-seconds

$R_{100 \% \text { range }}:$ miles available at $100 \%$ charge in miles

$R_{c e n}:$ the cell resistance in cm-ohms.

$r_{g b}$ gearbox ratio

$R_{P_{r e}-C_{a r g}}:$ miles available in the vehicle after running 100 miles with $80 \%$ of the battery in miles

$R_{r}$ DFIG rotor side copper resistance in ohms 
$R_{s}$ DFIG stator side copper resistance in ohms

$R_{u}$ : universal gas constant, $8.314 \mathrm{~J} /(\mathrm{mol}-\mathrm{K})$

$\Delta S(T)$ : change in entropy as a function of temperature $\mathrm{T}$ in $\mathrm{J} /(\mathrm{mol}-\mathrm{K})$

s: DFIG generator slip

$\mathbf{s}_{\text {input }}:$ entropy input in $\mathrm{J} /(\mathrm{g}-\mathrm{K})$

$\mathrm{s}_{\text {output }}$ entropy output in $\mathrm{J} /(\mathrm{g}-\mathrm{K})$

$t$ : cell discharge time in seconds

$\mathrm{T}$ : cell temperature in Kelvin

$\mathrm{T}_{0}$ : Temperature at freezing point, $0^{\circ} \mathrm{C}$ or $273.15 \mathrm{~K}$.

$\mathrm{T}_{\text {ambient }}$ ambient temperature in kelvin

$t_{\text {charge }}:$ time it takes to charge the car from when it ran 100 miles back to eighty percent in minutes

$T_{\text {inlat }}:$ compressed hydrogen inlet temperature in Kelvin

$V_{D C}:$ IGBT DC output voltage

$V_{C E(s a t)}:$ IGBT collector saturated voltage in volts

$V_{c e l l}:$ cell potential voltage in volts 
$V_{\text {cell dis }}$ : cell discharge voltage in volts

$V_{\text {cell } c h}$ : cell charging voltage in volts

$V_{E}:$ electrolysis voltage in volts

$\dot{V}_{H_{2}}$ : electrolysis hydrogen volumetric flow rate in $\mathrm{m}^{3} /[$ unit time $]$ cubic meters per unit time $V_{\text {port }}:$ fast charging station port input voltage

$V_{g}$ : DFIG stator voltage in volts

$V_{\text {wind }}:$ wind speed in $\mathrm{m} / \mathrm{s}$

$W_{\varepsilon, \max }:$ maximum electrochemical cell electrical work in Joules

$w_{H_{2}, \text { theoretical }}:$ specific theoretical work required to produce liquid hydrogen under ideal conditions in $\mathrm{kWh} / \mathrm{kg}$

$w_{H_{2} \text { plantapacity }}$ : specific energy consumed by hydrogen liquefier when operated at plant capacity in $\mathrm{kWh} / \mathrm{kg}_{\varphi_{s}}$ : stator phase angle in degrees

$\phi_{\text {perfomance }}$ : compressor coefficient of performance in normalized values

$\omega_{\text {turbine: }}:$ wind turbine angular speed in $\mathrm{rad} / \mathrm{s}$.

$\rho_{\text {air }}:$ ambient air density in $\mathrm{kg} / \mathrm{m}^{3}$ 
$\rho_{L H_{2}}:$ liquid hydrogen density in $\mathrm{kg} / \mathrm{m}^{3}$

$\lambda$ : tip speed ratio

$\beta$ is the blade pitch angle in ${ }^{\circ}$.

$v:$ molar flow in $\mathrm{mol} / \mathrm{s}$

$\eta_{A C D C}:$ ACDC rectifier efficiency in percent

$\eta_{\text {battery }}:$ lithium-ion battery efficiency in percent

$\eta_{e}:$ cell coulombic charge efficiency in percent

$\eta_{\text {charging port }}:$ DC cast charging port efficiency in percent

$\eta_{D C D C}:$ DCDC buck converter efficiency in percent

$\eta_{\varepsilon}:$ cell energetic charge efficiency in percent

$\eta_{\text {eleotrolysis }}$ : electrolysis efficiency in percent

$\eta_{f w E l \text { cell }}:$ fuel cell efficiency in percent

$\eta_{g a a r}:$ gearbox efficiency in percent

$\eta_{G H_{2} \text { comp }}$ : hydrogen compressor efficiency in percent

$\eta_{\text {isentropio }}$ : hydrogen compressor isentropic efficiency in percent 
$\eta_{\text {liquefiem }}:$ liquefier efficiency in percent

$\eta_{L H_{2} \text { motor }}:$ hydrogen liquid pump motor efficiency in percent

$\eta_{L H_{2} \text { pump }}:$ hydrogen liquid pump efficiency in percent

$\eta_{\text {overall electric }}$ overall electric efficiency in percent

$\eta_{\text {rotor: }}:$ rotor side efficiency in percent

$\eta_{\text {stator }}$ : stator side efficiency in percent

$\eta_{\text {traction battery: }}$ traction battery efficiency in percent

$\eta_{v}$ : cell voltaic charge efficiency in percent

$\bar{x}$ : average of a variable over a number of samples

$x_{i}$ : value of a specific sample being used to find the average

$N$ : number of samples whose values are being used to find the average

$\sigma$ : standard deviation of the averaged samples. 


\section{$\underline{\text { List of Tables }}$}

Table 2.1: List of Wind Farm in West Virginia (Wind Energy in West Virginia, 2020). 12

Table 3.1: Comparison of different BEV batteries for a typical size of $250 \mathrm{~kg}$ (Broussely, 2007).

Table 3.2: Comparison of different BEV batteries for a typical size of 200 L (Broussley, 2007).

Table 3.3: Comparison of different BEV batteries for a typical size of $250 \mathrm{~kg}$ (Broussley, 2007).

Table 4.1: Wind turbine data obtained from

https://www.thewindpower.net/turbine_en_561_mitsubishi_mwt-95.php 47

Table 4.2: Data on rotor side power converter used to calculate power converter losses on the

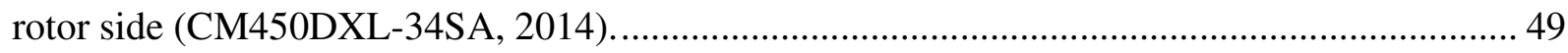

Table 4.3: Lithium ion battery technologies developed so far (Julien, 2016). ........................... 50

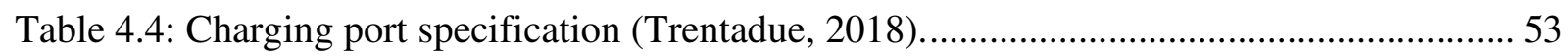

Table 4.5: Values that will be used based on assumptions made based on duty-cycle eccentricity

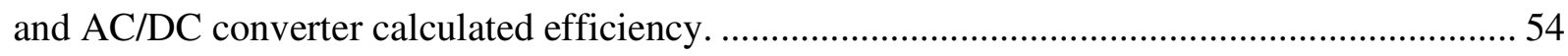

Table 4.6: BEV operation range data collected (Fuel Economy Guides, 2019 and 2020).......... 55

Table 4.7: Electrolysis data from Nel Hydrogen model M100 (Nel Hydrogen, 2020 and HDSAM

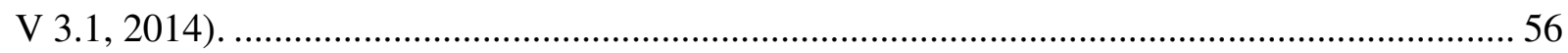

Table 4.8: Data obtained from electrolyser from HDSAM (HDSAM3.1, 2014)........................ 56

Table 4.9: Inlet and outlet pressure at each stage of the compressor......................................... 57

Table 4.10: Data obtained from NIST to calculate the ideal amount of work done on the liquefier

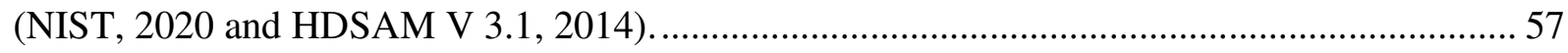


Table 4.11: Hydrogen liquid pump data (HDSAM V 3.1, 2014 and NIST, 2020).

Table 4.12: Hydrogen pre-chiller data obtained from HDSAM and NIST hydrogen table properties.

Table 4.13: Data collected on fuel cell vehicles (Fuel Economy Guides, 2019 and 2020).

Table 5.1: List of specific energy consumption by different equipment in the liquid hydrogen

scenario.

Table 5.2: List of specific energy consumption by different equipment in the compressed

hydrogen scenario.

Table 6.1: BEV available energy before and after charging, charging time needed after running

100 miles in a combined city and highway setting. 67

Table 6.2: BEV available energy before and after charging, charging time needed after running 100 miles in a city setting.

Table 6.3: BEV available energy before and after charging, charging time needed after running 100 miles in a highway setting. 68

Table 6.4: Scenario 2 Electrical energy consumed over 100 miles at $77^{\circ} \mathrm{F}$ ambient temperature with compressed hydrogen in $\mathrm{kWh}$.

Table 6.5: Amount of DFIG energy consumed by each fuel cell car with liquid hydrogen in kWh.

Table 6.6: Difference between hydrogen fuel cell and electric vehicles energy consumption..... 77

Table 6.7: Percent difference between hydrogen fuel cell and electric vehicles energy

consumption. 77 


\section{$\underline{\text { List of Figures }}$}

Figure 1.1: Scenario 1 where wind energy is used to charge BEV 3

Figure 1.2: Scenario 2A where wind energy is used to produce hydrogen through electrolysis, power the hydrogen compressor, and pre-cool the hydrogen so compressed hydrogen can be used

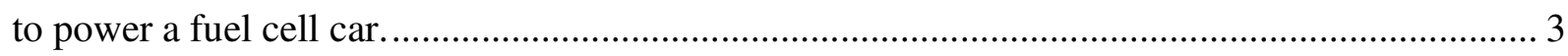

Figure 1.3: Scenario 2B where wind energy is used to produce hydrogen through electrolysis, power the hydrogen liquefaction system, power the hydrogen liquid pump, and pre-cool the hydrogen so liquid hydrogen can be used to power a fuel cell car. 4

Figure 2.1: United States energy generation by source. (U. S. Facts Explained, 2020) ................ 5

Figure 2.2: United States renewable energy generation by source. (U. S. Facts Explained, 2020) 6 Figure 2.3: Wind turbine structure, components, and how components work together to generate energy from wind (The Inside of a Wind Turbine, 2020). 9

Figure 2.4: Downwind rotor faces opposite to wind direction while upwind rotor faces directly the wind (Hitachi, 2020). 10

Figure 2.5: Fuel cell operation basic diagram (Erjavec, 2013). 14

Figure 2.6: Fuel cell operating in a vehicle (Erjavec, 2013). 15

Figure 2.7: Electrolysis basic operation diagram (Erjavec, 2013). 16

Figure 3.1: Double Feed Generator Schematic (Tamura, 2012). 20

Figure 3.2: Power coefficient as a function of the blade pitch angle and the tip speed ratio. 22

Figure 3.3: DFIG equivalent circuit (Wu, 2011). 23

Figure 3.4: DFIG equivalent circuit power flow on (a) super-synchronous mode and (b) subsynchronous mode (Wu, 2011). 25 
Figure 3.5: Level 1 public charger (2020 Guide On How To Charge Electric Car With Charging Stations, 2020). 32

Figure 3.6: Level 2 public charger (2020 Guide On How To Charge Electric Car With Charging Stations, 2020). 33

Figure 3.7: Level 3 public charger (2020 Guide On How To Charge Electric Car With Charging Stations, 2020). 33

Figure 3.8: Main thermodynamic functions (Millet \& Grigoriev, 2013). 40

Figure 3.9: Hydrogen phase curve (Godula-Jopek, 2020). 42

Figure 3.10: Use transport energy derived from renewable electricity to power BEV and FCEV

(Bossel, 2006). 46

Figure 4.1: Summary for induction machine operating at generating and motoring modes $(\mathrm{Wu}$, 2011). 48

Figure 4.2: Measured round trip charge and discharge efficiencies as function of duty cycle eccentricity (Valøen and Shoesmith, 2007)......

Figure 4.3: CHAdeMO Connector (2020 Guide On How To Charge Electric Car With Charging Stations, 2020). 52

Figure 4.4: Charging vehicle seen as a storage capability (Sumper, 2016). 52

Figure 4.5: Corresponding weights of several batteries of different specific energy (Broussely, 2007). 54

Figure 6.1: Battery energy available before charging 70

Figure 6.2: Pre-charge range availability of cars at different settings. 71

Figure 6.3: Time taken to charge the BEV back to $80 \%$. 72

Figure 6.4: Amount of energy from the battery bank consumed to charge back to $80 \%$. 73 
Figure 6.5: Energy consumed when compressed hydrogen is used at combined city and

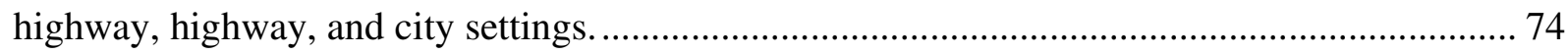

Figure 6.6: DFIG energy consumed with liquid hydrogen at combined city and highway.

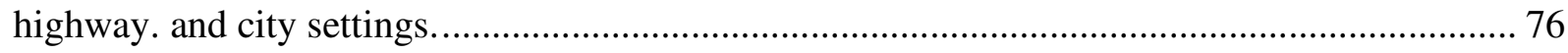




\section{Introduction}

\subsection{Overview}

Due to concerns about climate change and dwindling fossil fuels, the predominant sources of energy used for transportation, there has been a quest for finding ways to power cars without the dependence on fossil fuels. According to EPA in 2020, approximately $29 \%$ of the greenhouse gas (GHG) emissions came from transportation sector. Between 1990 and 2017, the amount of GHG emissions is more in absolute terms than in any other sector (Transportation and Climate Change, 2020).

The EPA is addressing the climate change issue by implementing programs such as setting GHG emission standards for cars and trucks. The EPA and the Department of Transportation (DOT) jointly created rules aiming to cutting six billion metric tons of GHG emissions over the lifetimes of vehicles sold in model years 2012-2025 and allowing flexibility for manufacturers to meet standards, nearly doubling the fuel efficiency while protecting consumer choice, and reduce America's dependence on oil and provide significant savings at the pump (Transportation and Climate Change, 2020).

\subsection{Addressing GHG Emissions}

The EPA's Renewable Fuel Standard (RFS), was created under the Energy Policy Act (EPAct) of 2005, amended the Clean Air Act (CAA). The Energy Independence and Security Act (EISA) 2007 further amended the CAA program by expanding the RFS. The RFS is a national policy that requires a certain volume of renewable fuel to replace or reduce the quantity of petroleum -based transportation fuel, heating oil, or jet fuel. The four renewable fuel categories are: biomass-based diesel, cellulosic biofuel, advanced biofuel, and total renewable 
fuel (Renewable Fuel Standard Program, 2020). Total renewable fuel is the category that will be addressed by this report. The use of wind energy to power hydrogen fuel cell and battery electric cars will be studied in this thesis.

\subsection{Scope of the Thesis}

The scope of this research involves using data from a wind turbine dual feed induction generator (DFIG) to determine how much power is required to power battery electric vehicles (BEVs) and fuel cell electric vehicles (FCEV). The process involves wind spinning the turbine rotor. Since the turbine rotor angular speed is too low to generate energy, a gearbox between the wind turbine and the DFIG increases the rotational speed so the rotor speed in DFIG is enough to generate energy. The DFIG generated power is split into two: the rotor side power and the stator power. Only the rotor side power will be addressed in this thesis since the rotor side power is stored in a giant battery onsite. Since the power generated in the DFIG is alternating current (AC), an alternating current to direct current (ACDC) insulated gate bipolar transistor (IGBT) rectifier is installed so the rotor side power is converted to DC power. The DC power is stored in a giant battery.

The scope is split into two different scenarios: energy stored in the battery is used to directly charge electric vehicles through direct current (DC) Fast Charging (see figure 1.1) or the energy stored goes through an electrolyzer, a device that uses current to split water into oxygen and hydrogen. The second scenario is further split into two different sub-scenarios. One sub-scenario hydrogen is compressed and pre-chilled so it can be used to fill-up a compressed hydrogen tank in a fuel cell car (see figure 1.2) while the other hydrogen is liquefied, pumped through a liquid pump, and is pressurized enough to be pre-chilled and then filled into the liquid hydrogen tank in a fuel cell car (see figure 1.3). 


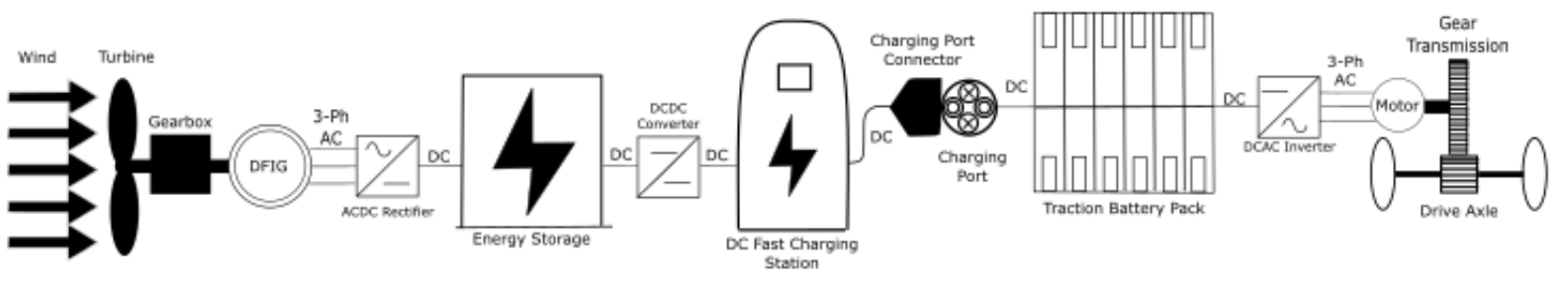

Figure 1.1: Scenario 1 where wind energy is used to charge BEV.

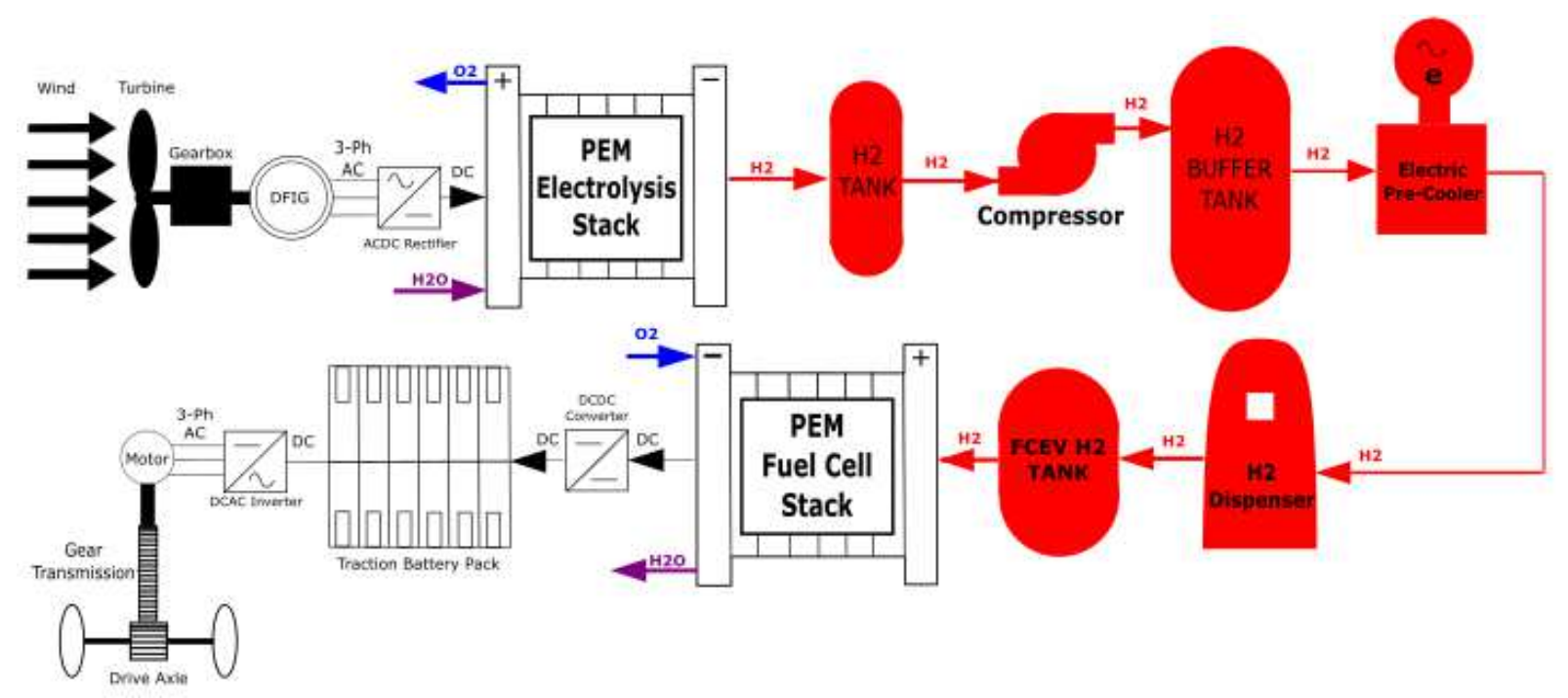

Figure 1.2: Scenario 2A where wind energy is used to produce hydrogen through electrolysis, power the hydrogen compressor, and pre-cool the hydrogen so compressed hydrogen can be used to power a fuel cell car. 


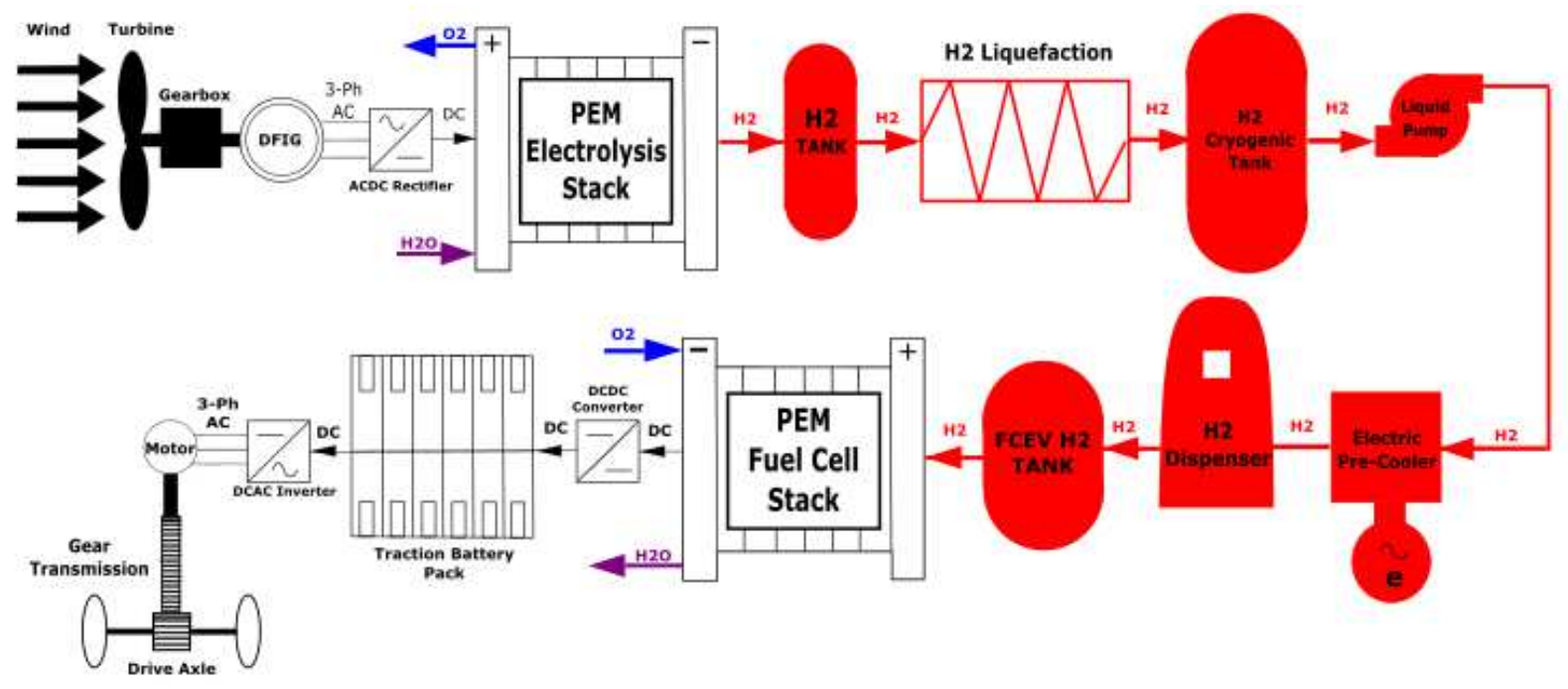

Figure 1.3: Scenario 2B where wind energy is used to produce hydrogen through electrolysis, power the hydrogen liquefaction system, power the hydrogen liquid pump, and pre-cool the hydrogen so liquid hydrogen can be used to power a fuel cell car.

Both scenarios will examine how much energy from the DFIG is consumed for car to run over

100 miles. The combination of efficiencies on these three scenarios will determine which

scenario is the best to achieve the goal established by the EPA and the DOT of reducing reliance on fossil fuels for transportation. 


\section{Literature Review-Renewable Electricity Production}

\subsection{Introduction}

In 2019, 100.2 Quadrillion British Thermal Units (BTU) energy have been consumed in the United States. Out of the total energy consumed, 37\% came from petroleum; $32 \%$ from natural gas; $11 \%$ from coal; $11 \%$ from renewables; and $9 \%$ from nuclear power as shown on Figure 2.1 (U. S. Facts Explained, 2020).

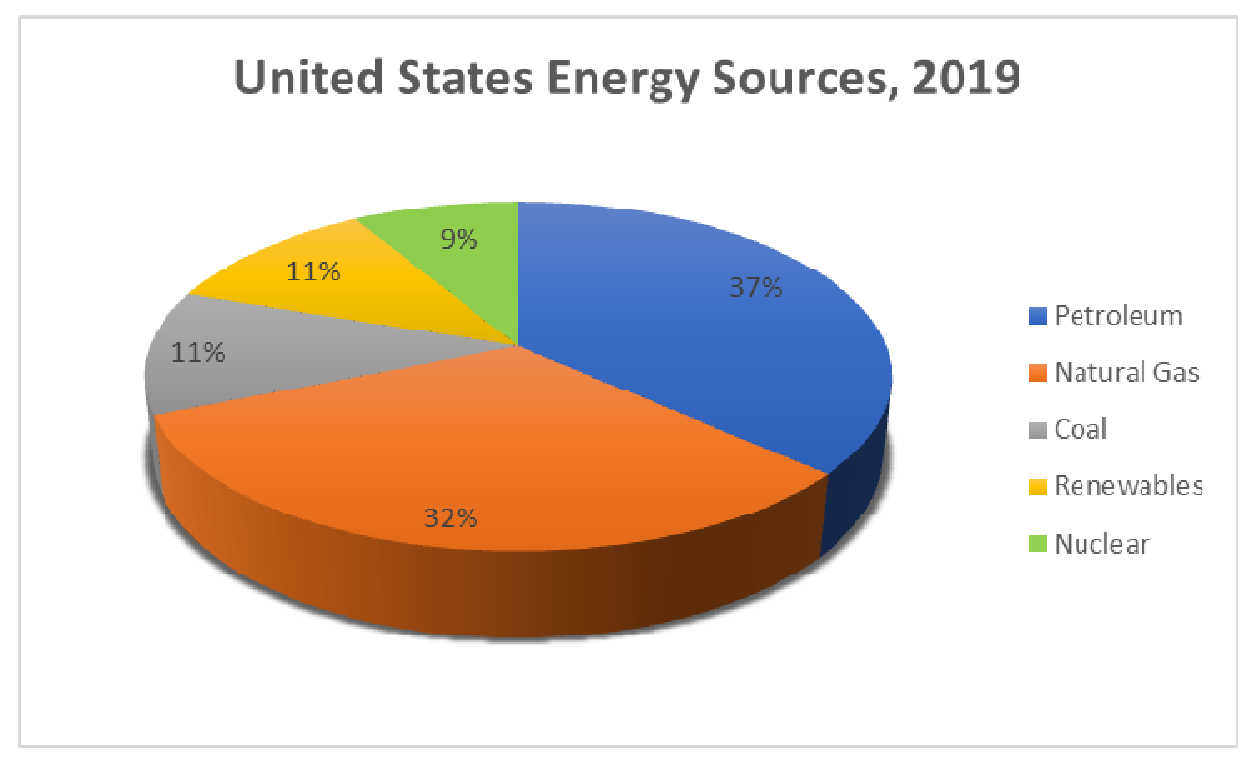

Figure 2.1: United States energy generation by source (U. S. Facts Explained, 2020).

Due to climate change and finite natural resources such as coal, crude oil, and natural gas, there has been more investment of renewable sources of energy such as biomass (biomass waste, biofuels, and wood); hydroelectric; wind; solar; and geothermal. The renewable energy sources are $43 \%$ biomass; $24 \%$ wind; $22 \%$ hydroelectric; $9 \%$ solar; and $2 \%$ geothermal as shown on figure 2.2 (Renewable Energy Explained, 2020). The sources of renewable energy considered the least polluting are solar and wind energy sources. 


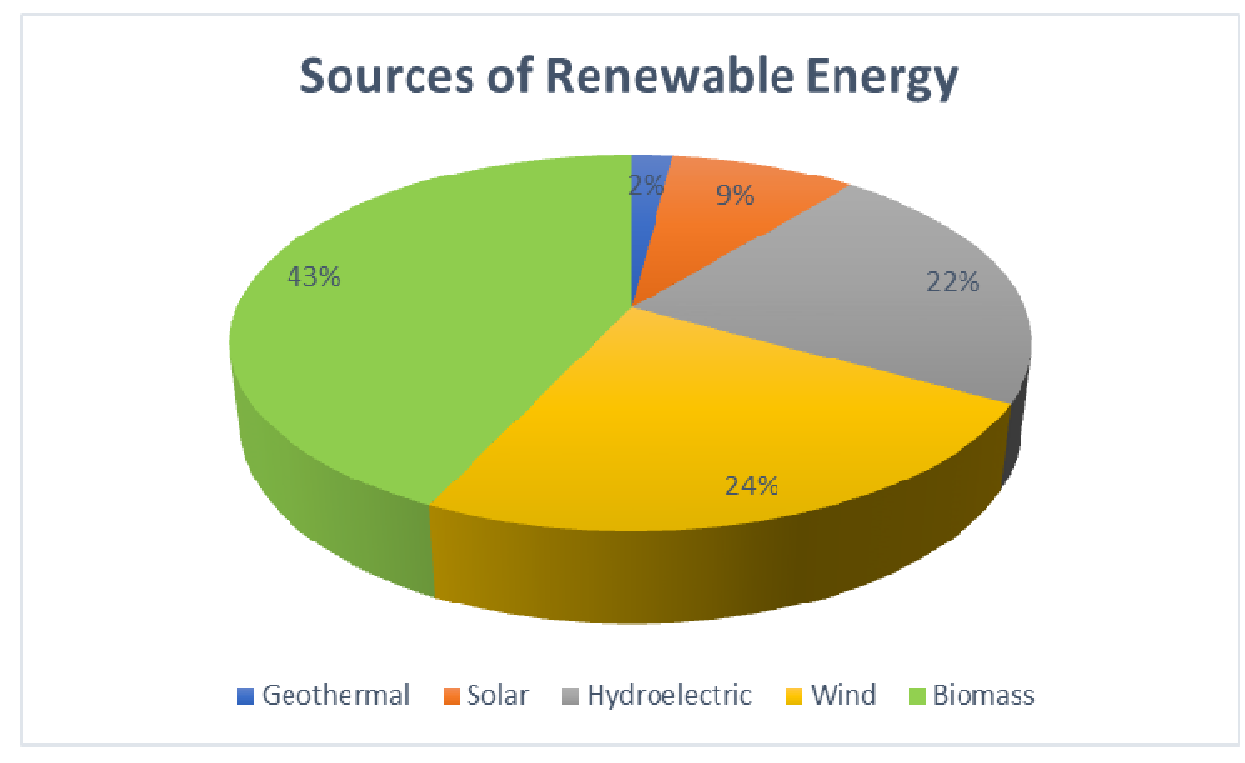

Figure 2.2: United States renewable energy generation by source. (U. S. Facts Explained, 2020).

\subsection{Solar Energy}

Sun's rays have been used by humans to warmth and drying food for thousands of years. An astronomer named John Herschel used a solar oven to cook his food during an expedition in Africa. Over time, solar technology has evolved to convert solar rays into electricity. Photovoltaic technology has been developed as a means of converting solar ray into electricity. A Photovoltaic array consists of several photovoltaic (PV) cells and each cell is made of a semiconductor material. Sunlight is composed of photons, which contain a varying amount of energy that correspond to the different wavelengths of the solar spectrum (Solar Explained, 2018).

When photons strike a PV cell, they may reflect, pass through, or be absorbed by the semiconductor material. The absorbed photons generate electricity. When the semi-conductor material absorbs enough sunlight, electrons are dislodged from the material's atom electricity. The semi-conductor material receives special treatment during manufacturing to make the front 
cell more receptive to the dislodged electrons, thus making them easier to migrate to the surface of the cell. The flow of the electrons towards the surface of the cell creates an imbalance between front and back surfaces. The imbalance between the front and back surfaces of the cell results in a voltage potential between positive and negative areas like in a battery. Electrical conductors on the cell absorb the electrons. When the conductors are connected in an electrical circuit to a battery or any other external load, the electricity generated flows in the circuit. Efficiency at which PV cells convert sunlight to electricity varies by semi-conductor material, ranging from 5 to $15 \%$ (Solar Explained, 2018).

Solar Irradiance is denser (above $6.5 \mathrm{kWh} / \mathrm{m}^{2} /$ Day in Southwestern United States, especially in Arizona, New Mexico, western Texas, southern Colorado, Utah, Nevada, and California, while least dense in the Pacific northwest, the great lakes region, northern Vermont, and northern New Hampshire (Roberts, 2018). Solar energy will be especially addressed in three states such as Ohio, Pennsylvania, and with special emphasis in West Virginia.

In the state of Ohio, as of 2019, a total of 207.84 MW is installed in Ohio. Currently the state ranks $29^{\text {th }}$ up from $32^{\text {th }}$ in 2018 with $0.35 \%$ of the energy produced being solar. The solar energy industry in Ohio has created 7282 jobs so far. There are 238 Solar Companies (99 manufacturers, 62 installers/developers, and 70 others). A total of US\$ 728.14 million have been invested on solar energy in the state while prices have fallen $40 \%$ over the last five year. There are 6033 solar installations (Ohio Solar, 2020).

In the state of Pennsylvania, a total of 540.78 MW of solar energy is installed. Currently the state ranks $22^{\text {nd }}$ up from $25^{\text {th }}$ in 2019 with $0.26 \%$ of the total energy produced being solar. The solar energy industry in Pennsylvania has created 4231 jobs so far. There are 451 solar companies (110 manufacturers, 255 installers/developers, and 116 others). A total of US\$ 
1906.31 million have been invested on solar energy the state while prices have fallen $40 \%$ over the last five years. There are 31335 solar installations in Pennsylvania (Pennsylvania Solar, 2020).

In the state of West Virginia, a total of $9.91 \mathrm{MW}$ is installed. Currently the state ranks $48^{\text {th }}$ up from $49^{\text {th }}$ in 2017 with $0.02 \%$ of the total energy produced being solar. The solar energy industry has created 340 jobs so far. There are 17 solar companies (4 manufacturers, 10 installers/developers, and 3 others). A total of US\$ 31.69 million have been invested in the state while prices have fallen $40 \%$ over the last five years. There are 302 solar installations in West Virginia (West Virginia Solar, 2020).

\subsection{Wind Energy}

The wind is one of the major sources of renewable energy to be relied upon in the future alongside with solar due to its reliability and abundance throughout United States. The wind turbine consists of several components that work together to make wind turbine operations and energy generation possible. The components of a wind turbine are: two or three blades; a rotor; a pitch system; a nacelle, which is located at the top of the tower and, contains the gear box, high speed shaft, low speed shaft, generator, controller, brake, an anemometer; a wind vane; the tower, containing the yaw drive and yaw motor (The Inside of a Wind Turbine, 2020).

The pitch turns blades out of the wind to control the rotor speed, and to keep the rotor from turning in winds that are too high or too low to produce electricity. The rotor is formed by the blades and hub together. The rotor is connected to the low-speed shaft spins at 30-60 rpm. The gear box connects the low-speed shaft to the high-speed shaft to increase the rotational speed from 30-60 rpm to about 1000-1800 rpm, the rotational speed required by most generators to produce electricity. The high-speed shaft drives the generator to produce 60-cycle AC 
electricity, which is usually an off-the-shelf induction generator. The anemometer measures the wind speed and transmits the speed to controller. The controller starts up the machine at wind speeds between 8 and $16 \mathrm{mph}$ and shuts off the machine if the wind speed reaches $55 \mathrm{mph}$ to prevent turbine damage. The brake stops the rotor mechanically, electrically, and hydraulically in case of emergencies. Since the wind speed increases with height above the ground, taller towers enable turbines to capture more energy, thus generating more electricity. The wind direction determines the design of the turbine. Upwind turbines face into the wind while downwind turbines face away (see Figure 2.4).

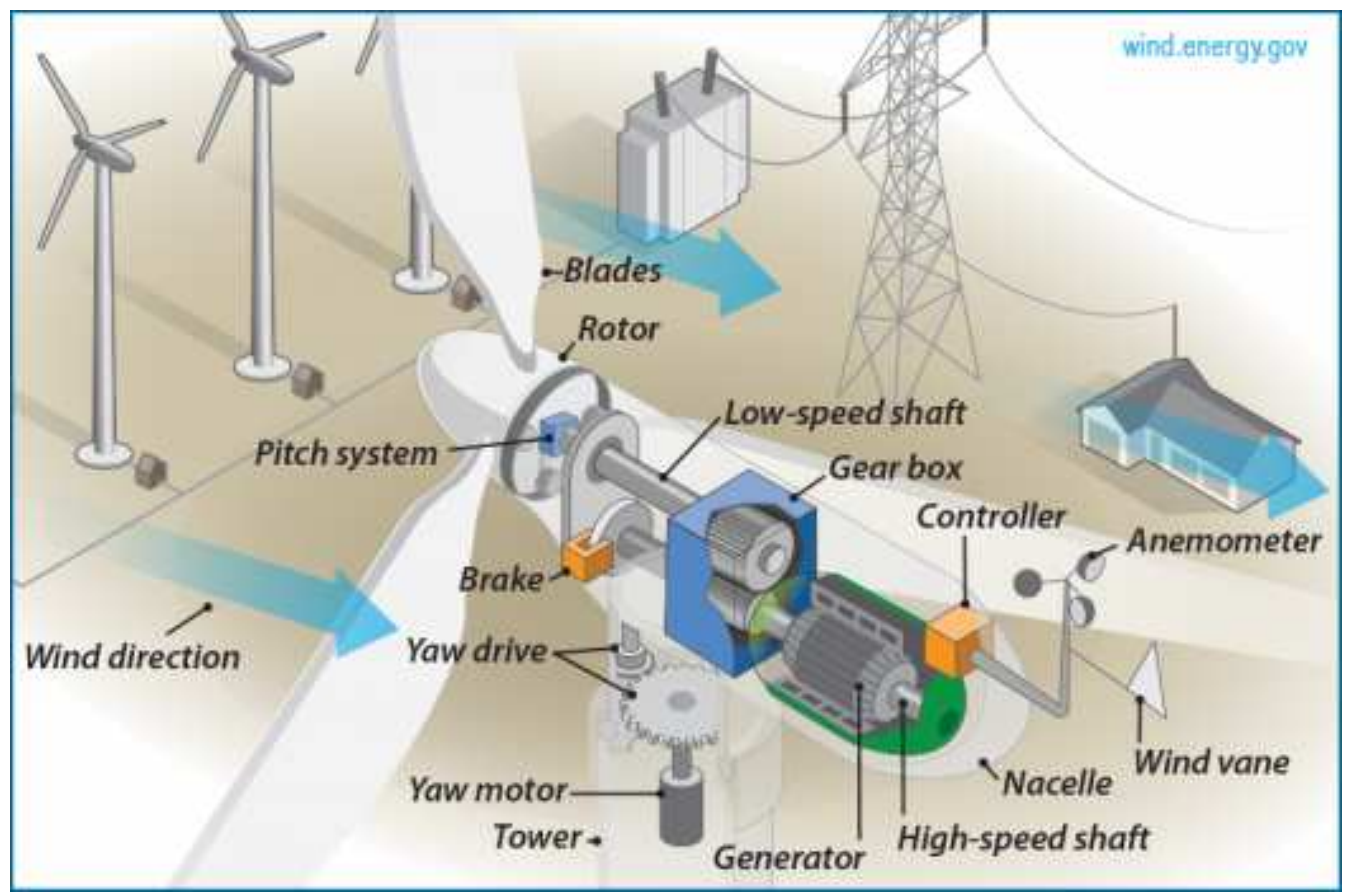

Figure 2.3: Wind turbine structure, components, and how components work together to generate energy from wind (The Inside of a Wind Turbine, 2020). 


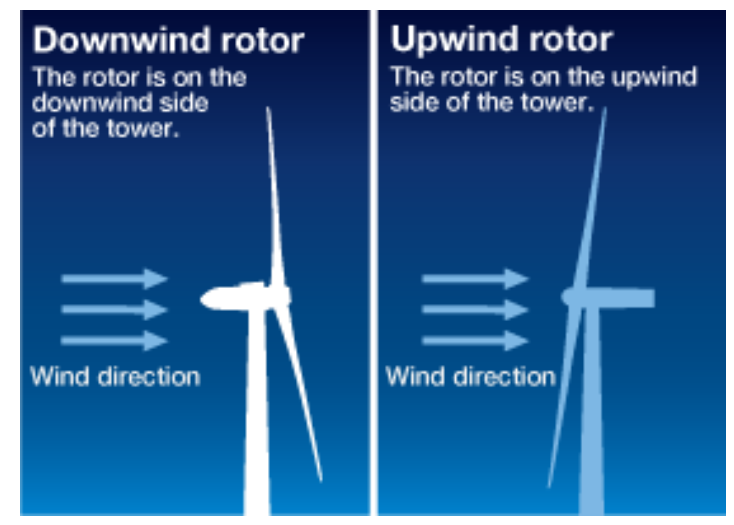

Figure 2.4: Downwind rotor faces opposite to wind direction while upwind rotor faces directly the wind (Hitachi, 2020).

The wind vane measures wind direction and communicates with the yaw drive to orient the turbine properly with respect to the wind direction. The yaw drive orients upwind turbines to keep them facing the wind when the wind direction changes. The yaw motor powers the yaw drive. Downwind turbines don't require a yaw drive because the wind manually blows the rotor away from it. The tower is made from tubular steel, concrete, or steel lattice. The tower supports the structure of the turbine (The Inside of a Wind Turbine, 2020).

Modern wind turbines have been modeled based on designs from the late 1950's. In 1956, Johannes Juul built the Gedser Wind Turbine. The turbine was a $200 \mathrm{~kW}$, three-bladed turbine, and had emergency tip breaks. The three blades and emergency tip breaks are features being used in turbine designs today. The turbine operated until 1967 and was refurbished in the mid 1970's at the request of NASA (Nixon, 2008). The oil shortage in the 1970's led the US government to begin research alternative sources of energy (Wind Explained, 2019). In the 1970's, the US Government, led by NASA began researching into large commercial wind turbines. In Ohio, thirteen experimental turbines were put in operation, leading the way into the multi-megawatt technologies being used today (Nixon, 2008). 
In 1980 the World's first windfarm was built in New Hampshire. The windfarm consisted of twenty wind turbines. The project proved to be a failure as the turbines would break down and the developers overestimated the wind resource availability (Nixon, 2008). In the 1980's thousands of wind turbines were installed in California, largely due to federal and state policies that encouraged renewable energy (Wind Explained, 2019).

In the 1990's and 2000's, the US Federal Government established incentives for renewable energy use due to environmental concern. Policies involve tax incentives on wind energy projects, which have resulted in increase in wind power. US Government also has been funding research and development projects to reduce wind energy costs. Less than $1 \%$ electrical energy was generated by wind power in 1990 in the United States (Wind Explained, 2019). In 2020, $2.6 \%$ of the electricity was generated in the United States by wind power (U. S. Facts Explained, 2020).

In the state of Pennsylvania, there are currently twenty-seven wind farms (Wind Energy, 2020). The installed wind capacity is 1459 MW. There are 90 MW of wind energy under construction. Currently, wind energy currently accounts for $1.54 \%$ of the energy generated in Pennsylvania (Wind Energy in Pennsylvania, 2020).

In the state of Ohio, the installed wind energy capacity is $864 \mathrm{MW}$ while $388 \mathrm{MW}$ are currently under construction. Wind energy currently accounts for $1.71 \%$ of the energy generated in Ohio (Wind Energy in Ohio, 2020).

In West Virginia, there are current seven windfarms (Renewable Energy, 2020). The installed capacity in the state is $686 \mathrm{MW}$. Wind energy currently accounts for $2.72 \%$ of the energy generated in the state (Wind Energy in West Virginia, 2020). Power generation from 
wind is on the increase, but most of West Virginia's wind potential is restricted to the narrow ridges in the state's northeast (Renewable Energy, 2019). The six farms are listed on table 2.1 below.

Table 2.1: List of Wind Farm in West Virginia (Wind Energy in West Virginia, 2020).

\begin{tabular}{|c|c|c|}
\hline Wind Farm & Power & Operator/Owner \\
\hline Beech Ridge Energy, LLC & $100.5 \mathrm{MW}$ & Invenergy Services, LLC \\
\hline Laurel Mountain & $97.6 \mathrm{MW}$ & AES Wind Generation, Inc. \\
\hline Mountaineer Wind Energy Center & $66 \mathrm{MW}$ & FPL Energy, LLC \\
\hline NedPower Mount Storm & $264 \mathrm{MW}$ & Shell Wind Energy, Inc. \\
\hline Pinnacle Wind Force, LLC & $55 \mathrm{MW}$ & Edison Mission Energy \\
\hline New Creek & $103 \mathrm{MW}$ & Enbridge \\
\hline
\end{tabular}

\subsection{Battery Electric Vehicles and Plug-in Hybrid Electric Vehicles}

Electric Vehicles, also known as Battery Electric Vehicles (BEV) use electric energy stored in batteries to power the drive or traction motors. Electric Vehicles have zero on-site emissions but are unable to travel far between battery discharges and batteries need to be replaced after several thousand discharge-charge cycles. Battery Electric Vehicles can conveniently be recharged at home. There are some public charging stations available in a few states. Due to limited travelling range, battery electric vehicles are ideal only for commuting and short distance trips (Erjavec, 2013).

Plug-in hybrid electric vehicles (PHEV) are defined as full hybrids with larger batteries and can be recharged by an electric power grid. Plug-in hybrids are equipped with a power 
socket that allows the batteries to recharge when the engine is not running. The power socket can be plugged into a normal 110-volt outlet. Plug-in hybrids can be driven in an electric mode only up to 60 miles without the engine running. Whenever the batteries run low, the engine starts and powers the vehicle and the generator to charge the batteries (Erjavec, 2013).

\subsection{Fuel Cell Vehicles}

\section{$\underline{\text { 2.5.1 Fuel Cell Technology Development }}$}

The concept of producing electricity by combining hydrogen and oxygen gas started in 1839, when William Robert Grove, a British scientist, was able to successfully prove that electrolyzis could be reversed. However, the fuel cell technology only came to be more than one century later, in 1959, when the first fuel cell was successfully developed. Even though the use of fuel cells has been increasing rapidly since then, fuel cells had not been developed and used unless the practicality and the necessity outweighed its high cost, such as space programs (Erjavec, 2013).

Once low-cost materials for fuel cells have been discovered, FCEV started to emerge. A single fuel cell produces less than one volt, therefore, several fuel cells connected in series produce enough voltage to power a FCEV. The fuel cells connected in series are known as fuel cell stacks due to fuel cells being layered and next to each other. A fuel cell has two electrodes: the anode that has positive charge and the cathode that has negative charge. The electrodes are separated from each other by an electrolyte and separators. Most often, the electrolyte is a polymer membrane, known as ion or proton exchange membrane (PEM) (Erjavec, 2013).

The PEM is the type of fuel cell most often used to power FCEV with its efficiency ranging from 40 to 60 percent. There are several other fuel cell technologies such as solid oxide, 
molten carbonate, direct methanol (uses methanol rather than hydrogen), phosphoric acid, and alkaline fuel cells (Erjavec, 2013).

\subsubsection{Fuel Cell Basic Operation Principle}

Fuel cell vehicles use hydrogen as fuel or energy source. Fuel cell generates electric power through a chemical reaction (see Figure 2.5). A fuel cell electric vehicle uses electricity generated by fuel cell to power the motors driving the wheel. Even though fuel cells power vehicles are powered by electricity, external sources of electricity are not needed to charge the batteries (Erjavec, 2013).

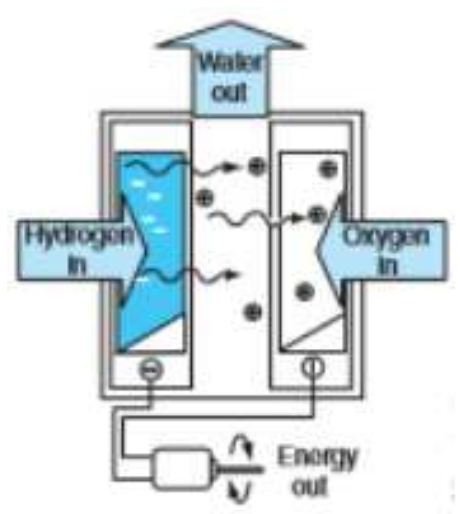

Figure 2.5: Fuel cell operation basic diagram (Erjavec, 2013).

The process in which fuel cells power the vehicle is as follows. When hydrogen is delivered to the anode, the catalyst causes hydrogen atoms to separate into protons and electrons. Electrons always gravitate towards the positivity of the protons, but cannot pass through the membrane, only through an external circuit connecting the cathode and anode. The movement of electrons through this external circuit results in direct current flow, which powers the electric motor in the FCEV. Oxygen enters the other side of the fuel cell and reacts to the catalyst on the cathode, which splits the oxygen molecules into oxygen ions. The hydrogen protons that enter the cathode 
through the membrane from the anode move towards the oxygen ions, while the oxygen electrons go through the external circuit. Each oxygen ion bonds with two hydrogen ions, forming water molecules. Some of the formed water keeps the ion exchange membranes moist while the remaining water is emitted as exhaust from fuel cells as shown in Figure 2.6 (Erjavec, 2013).

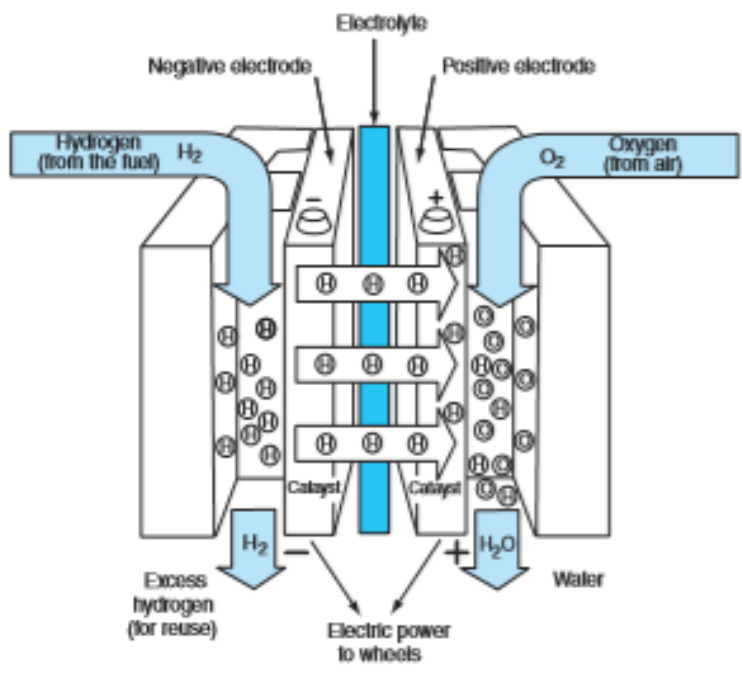

Figure 2.6: Fuel cell operating in a vehicle (Erjavec, 2013).

\section{$\underline{\text { 2.5.3 Electrolyzer Technology Development }}$}

Electrolysis is the process of using electricity to split water into hydrogen and oxygen. The reaction takes place in an electrolyzer, which consists of an anode and a cathode separated by an electrolyte (Hydrogen Production: Electrolysis, 2019). 


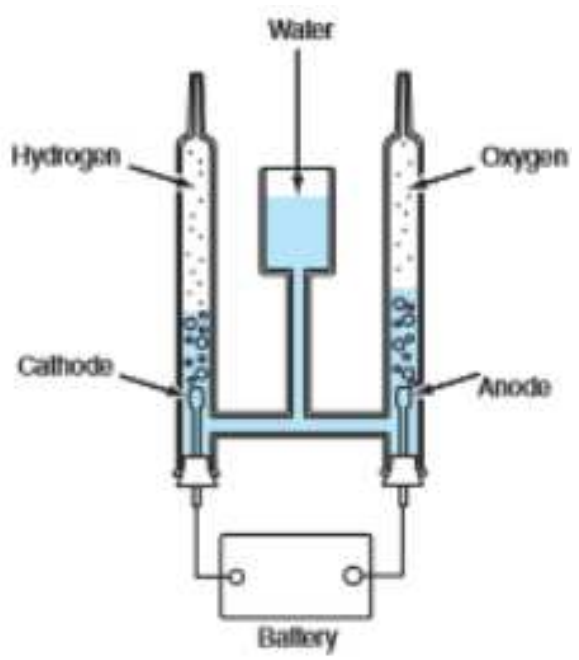

Figure 2.7: Electrolysis basic operation diagram (Erjavec, 2013).

Water electrolysis was first performed in 1800 by English Scientists William Nicholson and Anthony Carlisle (see Figure 2.7). Months later, the experiment was repeated by German Scientist Johann Ritter, who was also the first scientist to ever collect oxygen and hydrogen evolving separately. The laws of electrolysis were then discovered by English Scientist Michael Faraday, who established the quantitative relationship between the amount of electricity $q$ passing through the electrode/electrolyte interface and then mass $m$ of substances in the electrolysis (redox) process (Millet \& Grigoriev, 2013):

$m=k_{q} \cdot q$

where:

$k_{g}=\frac{M}{n \cdot F}$

is the electrochemical equivalent in $\mathrm{kg} / \mathrm{C} \equiv \mathrm{kg} /(\mathrm{A} \cdot \mathrm{s}) ; M$ is the molar mass produced by the substance at interface; $n$ is the number of electrons involved in the electrochemical reaction; $F=$ 
96,485.3 C/mol is the Faraday's constant. Faraday's law has been strictly verified by determining mass conservation (Millet \& Grigoriev, 2013).

A practical condition is that new species formed at both interfaces (anode and cathode) are fully separated and do not spontaneously react with each other. Concerning water electrolysis, when the steady state (stationary electric current $I$ and time period $t$ are known, the theoretical (maximum) amounts of hydrogen (or oxygen) produced can be calculated using:

$V_{\text {ther }}=\frac{k_{g} \cdot I \cdot t}{\rho}$

where $k_{e}$ is $V_{\text {theor }}$ is the theoretical volume of the gas evolved in $\mathrm{m}^{3}, I$ is the total current in amps, $t$ is the time in seconds, and $\rho$ is the gas density in $\mathrm{kg} / \mathrm{m}^{3}$ (Millet \& Grigoriev, 2013).

Despite the electrolysis' discovery in 1800 , electrolyzers were only developed in industrial scales more than one hundred years later in countries where hydropower was cheap and abundant. In 1927, the Norwegian developed the first water-alkaline electrolyzer for the synthesis of ammonia. In 1948, the first pressurized electrolyzer was developed and operated by Zdansky/Lonza. In 1966, the first solid polymer electrolyte (SPE) electrolyzer was built by General Electric. In 1972 and 1978, respectively, the development of solid-oxide water electrolysis (SOWE) and advanced alkaline water electrolysis took place (Millet \& Grigoriev, 2013).

\subsubsection{Electrolysis Applications}

Over the last decades, new applications of hydrogen as energy carrier, for example, in the stored energy obtained from renewable energy sources were found. Applications include regulation of the electrical grid (peak shaving), energy storage so electricity and heat can be produced at times when renewable sources cannot produce energy, analytical instrument 
(equipment for gas chromate graphs), correction systems for nuclear reactor water chemistry mode, high purity metals and alloys in metallurgy, high purity materials for the electronics industry and hydrogen welding (Millet \& Grigoriev, 2013). 


\section{Wind Energy Production and Its Application in Driving Car}

\subsection{Powering Vehicles with Wind Energy}

Increase in demand for cars has led to increase in oil consumption. Increase in oil consumption has led to increase in air pollution (Chen, 2017). Global Warming lead by Anthropogenic Greenhouse Gas Emissions is becoming more apparent. Depletion in fossil fuel has also become a major problem (Bellekom, Benders, Pelgrom, and Moll, 2012). Increase in air pollution has led to demand for the development of electric cars. Electric vehicles can help achieve energy conservation and emission reduction (Chen, 2017). There is increasing interest in powering car by green energy such as electricity produced by wind mill and solar panel.

\subsection{Scenarios 1 and 2: Power Generated by Wind}

\subsubsection{Local Geographical Aspects of Wind}

Several factors make the circular wind flow not uniform: the proportion of land and sea, the size of land masses, and the presence of mountains or planes. Wind speed tends to be higher on top of hills and mountains than they would be on a sheltered valley. The type of vegetation may also have a significant effect on the absorption or reflection of solar energy, affecting surface temperatures and air humidity. Trees and buildings significantly reduce wind speed (Tamura, 2012).

\section{$\underline{\text { 3.2.2 Wind Turbine Model }}$}

The turbine being investigated is a Mitsubishi MWT-95/2.4 (Project X 8760.xls) and has a double fed induction generator (Mitsubishi MWT-95/2.4). A DFIG consists of a rotor side and a stator side. The rotor side can either send the energy generated from the DFIG to a battery bank that lies between the ACDC rectifier and the DCAC inverter or take in energy stored from the 
battery bank. The battery bank can take energy either from the DFIG or the grid when the wind turbine is unable meet the demand or when the wind speed is too low (Tamura, 2012). Figure 3.1 shows the schematic of a DFIG.

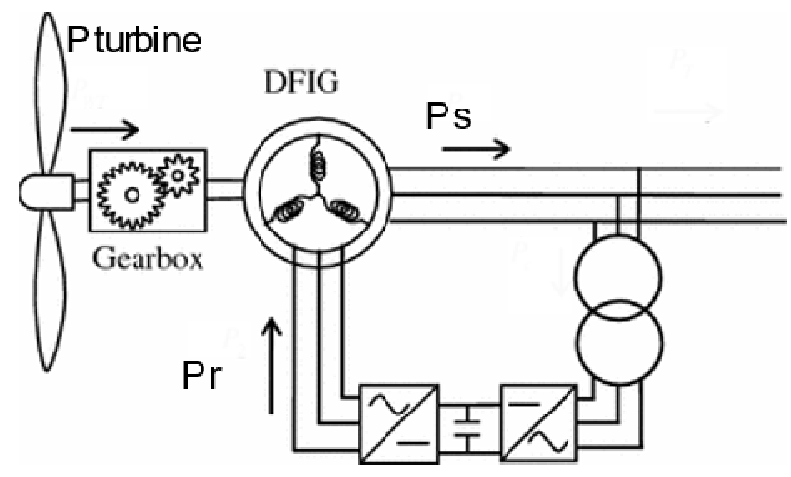

Figure 3.1: Double Feed Generator Schematic (Tamura, 2012).

\subsubsection{Wind Speed and Power}

Since the power of the wind turbine is proportional to the wind velocity cubed, the wind speed is the most important factor in determining the amount of power generated (Capehart, 2016). The power output of the wind turbine can be calculated by the following equation (Tamura, 2012):

$P_{\text {wind }}=\frac{1}{8} \rho_{\text {air }} \cdot \pi \cdot D_{\text {rotor }}^{2} \cdot V_{\text {wind }}{ }^{3}$

A lot of power is lost and only some of the power is captured by the turbine. The power captured by the turbine is shown by the following equation ( $\mathrm{Wu}, 2011$ and Tamura, 2012):

$P_{\text {turbine }}=P_{\text {wind }} \cdot C_{P}(\lambda, \beta)$

where $P_{\text {turbine }}$ is the power generated by the wind turbine in Watts, $\rho_{\text {air }}$ is the air density in $\mathrm{kg} / \mathrm{m}^{3}$, $\mathrm{C}_{\mathrm{p}}$ is the power coefficient of the turbine, $D_{\text {rotor }}$ is the diameter of the wind turbine rotor in 
meters, and $V_{\text {wind }}$ is the wind speed in meters per second. The power coefficient is defined as the ratio of the power output over the power input and is a function of the tip speed ratio $\lambda$, as shown by equation $3.3(\mathrm{Wu}, 2011$ and Tamura, 2012):

$\lambda=\frac{\omega_{\text {twraine }} \cdot D_{\text {rotwr }}}{2 \cdot V_{\text {wind }}}$

where $\omega_{\text {turbine }}$ is the mechanical angular speed $(\mathrm{rad} / \mathrm{s})$ of the turbine. Equation 3.4 shows the power coefficient equation as:

$C_{p}\left(\lambda_{2} \beta\right)=\frac{1}{2}\left(\Gamma-0.22 \beta^{2}-5.6\right) e^{-0.017 T}$

where:

$\Gamma=\frac{D_{\text {rotor }}}{2 \cdot \lambda} \cdot \frac{3600}{1609}$

and $\beta$ is the blade pitch angle in degrees. Figure 3.2 shows how the blade pitch angle defines the curve of the power coefficient, therefore has a significant impact on the power coefficient $(\mathrm{Wu}$, 2011 and Tamura, 2012). 


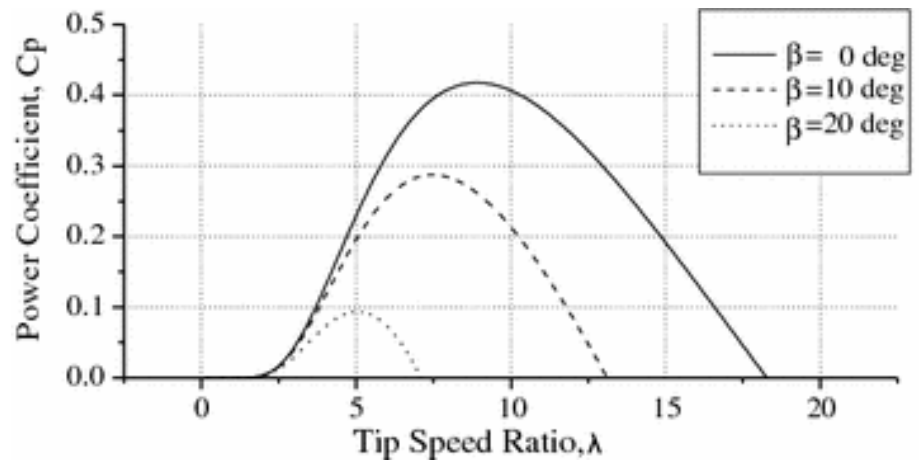

Figure 3.2: Power coefficient as a function of the blade pitch angle and the tip speed ratio.

The $C_{P}$ has a theoretical maximum known as Betz limit, which is roughly $59 \%$. Realistically, the wind turbine coefficients range from $20 \%$ to $50 \%$ (Wu, 2011).

\subsubsection{Mechanical Power Losses and Efficiency}

Since the rotor blades operate at speeds ranging between 6 to $20 \mathrm{rpm}$, usually much slower than the required speed (1000 to $1500 \mathrm{rpm}$ to operate a $50 \mathrm{~Hz}$ or 1200 to $1800 \mathrm{rpm}$ to 60 $\mathrm{Hz}$ generator), a gear box is necessary to increase the rotational speed of the generator (Wu,2011). The gearbox equation used to determine the gearbox ratio is given by:

$r_{g b}=\frac{n_{r}}{n_{w t}}=\frac{(1-s) \cdot 60 \cdot f_{g}}{P \cdot n_{w t}}$

where $s$ is the rated generator slip, $n_{r}$ is the rotor speed in rpm, $n_{w t}$ is the wind turbine speed in $\mathrm{rpm}, f_{s}$ is the stator frequency in Hertz, and $P$ is the number of pole pairs. Usually the rated slip is roughly one percent for induction generators, the gear ratio as a function of rated turbine speed can be determined through the following equation:

$$
P_{\text {mech }}=P_{\text {turbine }}-0.01 \cdot q_{\text {staps }} \cdot P_{\text {ratsd }}
$$


where $P_{\text {mech }}$ is the gear box power output and mechanical input power, $q_{\text {steps }}$ is the number of steps in the gearbox. Gear box losses happen due to tooth contact losses and lubricating oil losses. Viscous loss can be assumed as constant at $1 \%$, and $P_{\text {rated }}$ is the rated turbine input power. Gear box efficiency can be calculated as (Tamura, 2012):

$\eta_{\text {gear }}=\frac{p_{\text {mech }}}{p_{\text {turbine }}} \cdot 100(\%)$

where $\eta_{\text {gear }}$ is the gear box efficiency in percent, steps in the gear box (maximum gear ratio is 6:1 thus two or three steps of gears are typically required) (Tamura, 2012).

\subsubsection{Copper Losses and DFIG Efficiency}

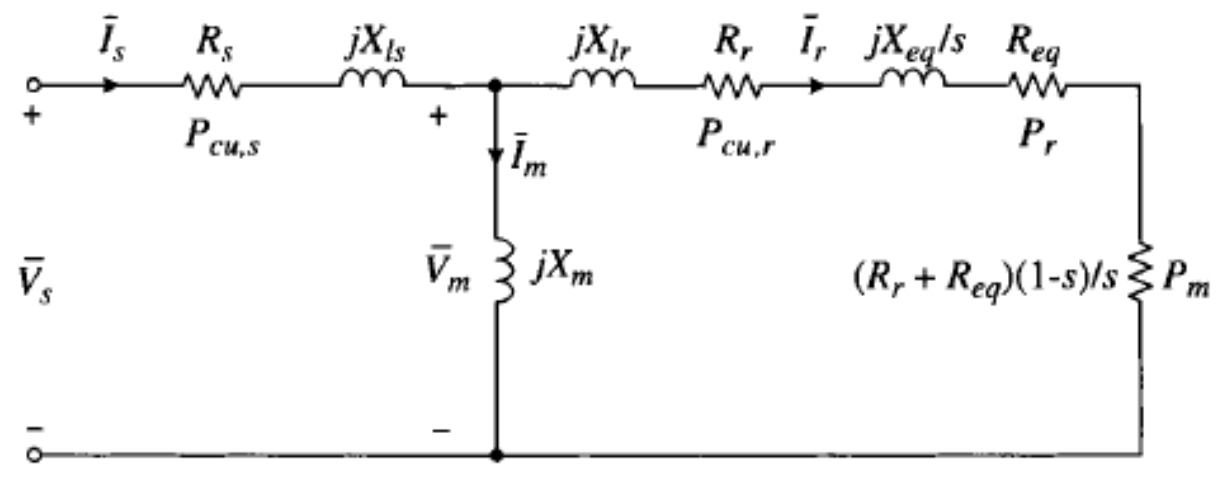

Figure 3.3: DFIG equivalent circuit (Wu, 2011).

From the equivalent circuit on Figure 3.3, the mechanical power can be calculated using the following equation $(\mathrm{Wu}, 2011)$ :

$P_{\text {mech }}=3 \cdot I_{r}^{2} \cdot\left(R_{e q}+R_{r}\right) \cdot\left(\frac{1-g}{s}\right)$

where $I_{r}$ is the rotor current in amps, $R_{e q}$ is the rotor side IGBT converter equivalent resistance in ohms, $R_{r}$ is the rotor side copper resistance loss, and $s$ is the slip between rotor and the stator. A DFIG has two operating modes: the sub-synchronous mode and the super-synchronous mode. 
The DFIG operates on sub-synchronous mode when power comes from either the grid through the power inverters or the stored battery while super-synchronous mode is when the DFIG supplies a maximum of $30 \%$ of its generated energy to the rotor side is stored. Figure 3.4 illustrates the power flow (Wu, 2011).

Since the rotor side and the stator sides of the DFIG need to be considered, equation (3.9) has been split into two equations (3.10) and (3.11):

$$
\begin{aligned}
& P_{\text {mech }}=P_{\text {mechrotor }}+P_{\text {mechstator }} \\
& P_{\text {machrotor }}=P_{\text {mach }} \times \frac{s}{(1-s)}
\end{aligned}
$$

The rotor power generated is calculated using the following equation

$$
P_{\text {rotor }}=3 \cdot I_{r}{ }^{2} \cdot R_{e q}=V_{D C} \cdot I_{C}+P_{\text {diss }}
$$

Where $P_{\text {rotor }}$ is the rotor generated power in watts, $I_{C}$ is the collector current, and $V_{D C}$ is DC output voltage, and $P_{\text {diss }}$ is the power dissipated from the ACDC converter in watts. The rotor side efficiency $\eta_{\text {rotor }}$ can be calculated using the following equation:

$\eta_{\text {rotor }}=\frac{P_{\text {rotur }}}{P_{\text {mech } / \text { rotor }}} \times 100 \%$

The stator power generated $P_{\text {stator }}$ can be calculated using the following equation:

$$
P_{\text {gtator }}=3 \cdot V_{s} \cdot I_{s} \cdot \cos \varphi_{s}
$$


where $V_{s}$ is the stator side voltage in volts, $I_{s}$ is the stator side current in amps, and $\varphi_{s}$ is the stator phase angle in degrees.

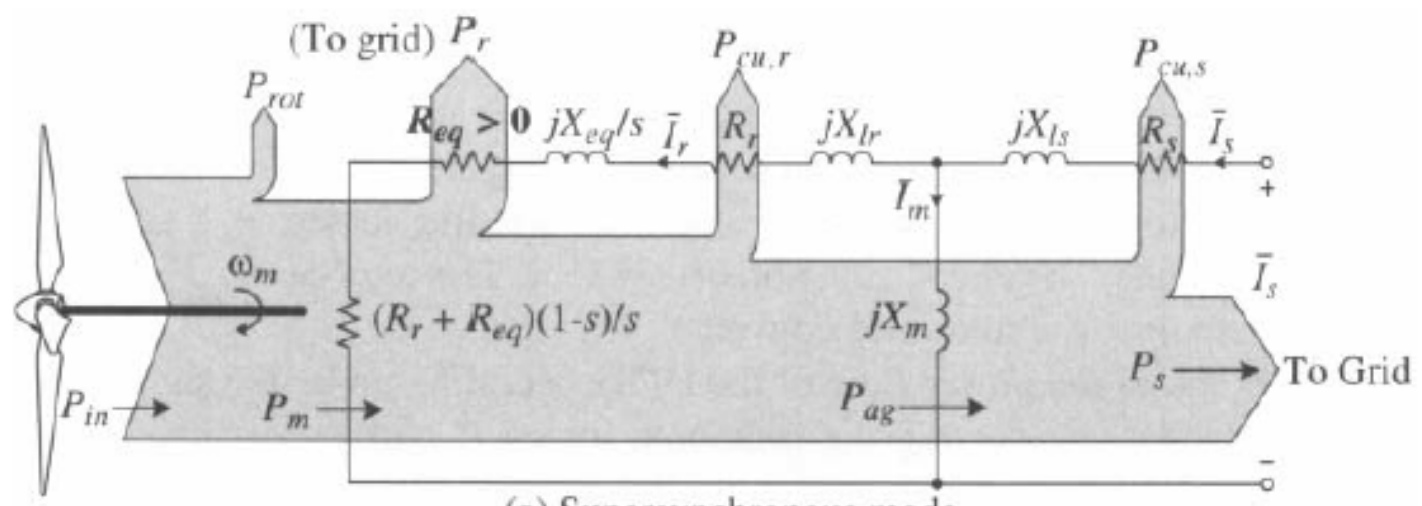

(a) Supersynchronous mode

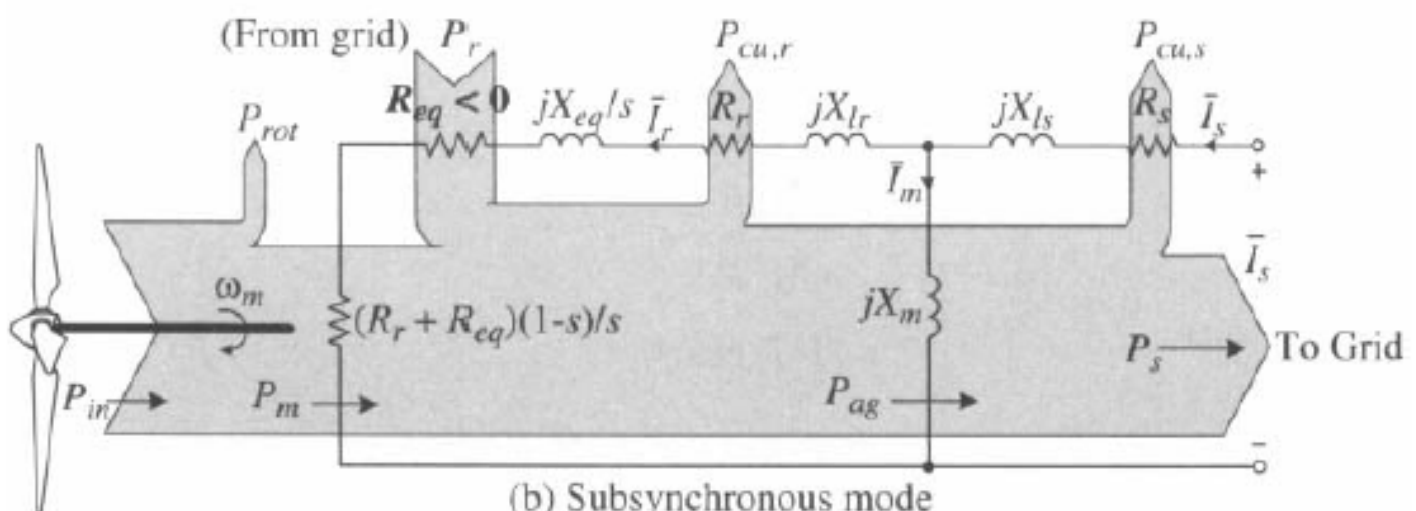

Figure 3.4: DFIG equivalent circuit power flow on (a) super-synchronous mode and (b) subsynchronous mode (Wu, 2011).

\section{$\underline{\text { 3.2.6 Power Converter Output }}$}

The maximum rotor power is roughly $30 \%$ of the stator power which goes to the ACDC converter located on the rotor side of the DFIG as shown on Figure 3.1 (Tamura, 2012). In order to store energy generated by the wind in the battery, a power converter is necessary to convert AC power to DC power. The power converter is composed of IGBT and forward (FWD) converters. Therefore, power converter loss is calculated as a summation of IGBT switching loss, 
reverse recovery loss of FWD, and steady-state losses of IGBT and FWD. The switching losses are calculated by equation 3.15 :

$P_{\text {ow }}=\frac{1}{2} \cdot\left(E_{\text {on }}+E_{\text {off }}\right) \cdot f_{\text {sw }}$

where $P_{s w}$ is the converter switching losses in watts, $E_{o n}$ is the energy switching on in $\mathrm{mJ}$ per pulse, $E_{\text {off }}$ is the energy switching off in $\mathrm{mJ}$ per pulse, and $f_{s w}$ is the maximum power converter frequency in $\mathrm{Hz}$ (Toshiba, 2020). The power conduction losses $P_{\text {cond }}$ is calculated with equation 3.16:

$P_{\text {eond }}=V_{C E(s a t)} \cdot I_{C}$

where $V_{C E(s a t)}$ is the saturation voltage in volts and $I_{C}$ is collector current in amps (Toshiba, 2020).The FWD power losses can be calculated as:

$P_{r r}=\frac{1}{2} \cdot E_{r r} \cdot f_{s w}$

where $E_{\mathrm{rr}}$ is the forward recovery switching energy in $\mathrm{mJ}$ per pulse. The overall power converter loss can be calculated using equation 3.18:

$P_{d i s s}=P_{s w}+P_{c o n d}+P_{r r}$

where $P_{\text {diss }}$ is the total power converter losses. The power output from the converter can be calculated using equation 3.19:

$P_{A C D C}=I_{C} \cdot V_{D C}$ 
where $P_{A C D C}$ is the output power from the power converter. The rectifier efficiency can be calculated using the following equation:

$\eta_{A C D C}=\frac{P_{A C D C}}{p_{\text {rotor }}} \times 100 \%$

\subsubsection{Energy Storage}

In order to make possible the use of wind energy in an electric car, a big battery would be necessary to store the electric energy onsite. Electrochemical systems have proven to be so far better than other forms of energy storage. Wind energy storage applications require high power capabilities, fast response, and long storage times. When requirement of high-power capabilities, fast response, and long storage times are combined with performance and costs, electrochemical systems have proven far superior to other forms of energy storage.

The cell potential of an electrochemical cell is the potential difference occurring between two electrodes of the cell and arises due to the transference of electrons through the external circuit of a cell that has not reached equilibrium. Cell potential is defined as the electrical work. Maximum electrical work can be derived from an electrochemical cell given by the Gibbs free energy change (Skyllas-Kazacos, 2010):

$W_{a, m a x}=\Delta G=-n \cdot E_{\text {mmf }} \cdot F$

Where $W_{e, \max }$ is the maximum electrical work in joules and $\Delta G$ is the Gibbs free energy change in joules, $n$ is the number of electrons transferred per unit overall reaction, $E_{\text {emf }}$ is the electromotive force of the cell, and $F$ is Faraday constant, which is 96485 coulombs per mole. Furthermore, the cell emf is related to the concentration of reactants and products via the Nernst equation (Skyllas-Kazacos, 2010): 
$E_{a m f}=E_{a m f}^{0}-\frac{R_{u} \cdot T}{n \cdot F} \cdot \ln Q_{k}$

where $E_{\text {emf }}^{0}$ is the standard electromotive force of the cell in volts, $R_{u}$ is the universal gas constant in joules per mole per Kelvin, $T$ is the cell temperature, and $Q_{R}$ is the reaction quotient, which is defined by the equation below:

$Q_{R}=\frac{[O x]}{[\text { Red }]}$

where:

$O x=[C]^{0}[D]^{d}$

$\operatorname{Red}=[A]^{a}[B]^{b}$

$a A+b B \rightleftharpoons c C+d D$

By combining equations from equation 3.22 to 3.26 , the electrochemical cell voltage can be determined from the electrolyte concentration. Due to irreversible losses within a cell, the actual potential voltage cell, $\mathrm{V}_{\text {cell }}$, is lower than the theoretical potential voltage cell. The losses occur due to three sources: activation polarization, ohmic polarization and concentration, and the result in an overall loss of potential, which can be expanded (Skyllas-Kazacos, 2010):

$V_{c e l l}=E_{m f}^{0}-E_{\text {lossgs }}=E^{\text {Cathode }}-E^{\text {Anode }}-E_{\text {cone }}-E_{\text {Act }}-i R_{c e l l}$ 
where $E_{\text {losses }}$ is the total voltage potential loss in volts, $E^{\text {cathode }}$ is the potential at the cathode relative to the reference electrode in volts, $E^{\text {anode }}$ is potential at the anode relative to the reference electrode in volts, $E_{\text {conc }}$ is the concentration overpotential in volts, $E_{\text {Act }}$ is the activation overpotential in volts, $i$ is the current density in amps per squared centimeters, and $R_{\text {cell }}$ is the cell resistance in centimeters-ohms.

At low current density, the activation polarization is dominant as barriers preventing current and ion flow need to be overcome. As current increases, activation losses begin to increase accordingly and since cell resistance remains constant. Concentration polarization or gas transport losses take effect at high current as this is where reactant flow to cell reaction sites becomes increasingly more difficult (Skyllas-Kazacos, 2010). If the cell operates in the current density region dominated by ohmic losses, the cell voltage equation can be simplified by:

$V_{c e n}=E^{\text {Cathode }}-E^{\text {Anode }}-i R_{\text {cen }}$

where $R_{\text {cell }}$ accounts for both ohmic and polarization losses (Skyllas-Kazacos, 2010).

The theoretical cell capacity is given by:

$Q_{T}=\oint I_{c a l l} \cdot d t=m \cdot n \cdot F$

Where $Q_{T}$ is the theoretical cell capacity in amps-seconds, $I_{\text {cell }}$ is the current passing through the cell in amps, $t$ is the discharge time in seconds, $\mathrm{m}$ is the number of moles or reactant required for complete cell discharge in moles, $\mathrm{n}$ is the number of electrons transferred in the reaction, and $F$ is the Faraday constant in coulombs per mole. 
Due to self-discharge and incomplete reaction at electrodes, the actual cell capacity is less than the theoretical value assuming all of the material utilized in the cell reactions play a role in the reaction. Cell capacity is described in terms of Watt-hours (Wh) or Ampere-hours (Ah).

The coulombic cell efficiency measures the amount of charge delivered by the discharge reactions of the cell relative to the number of coulombs used to discharge each cell (SkyllasKazacos, 2010). Coulombic efficiency $\eta_{c}$ is calculated by the following equation:

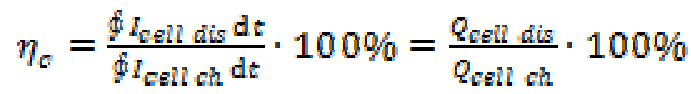

where $I_{\text {celldis }}$ is the discharge current in amps, $I_{\text {cellch }}$ is the charge current in amps, $Q_{\text {celldis }}$ is the cell discharge capacity in coulombs, and $Q_{\text {cellch }}$ is the charge current in coulombs. Coulombic inefficiency can be minimized by including voltage control to prevent side reactions such as solvent breakdown during charging (Skyllas-Kazacos, 2010).

Voltage efficiency measures the effects of cell polarization or cell losses. Voltage efficiency $\eta_{v}$ is calculated by the following equation:

$\eta_{v}=\frac{\oint V_{c \varepsilon l d i \mathrm{~d}} \cdot d t}{\oint V_{c e l l} \cdot d t} \cdot 100 \%$

Where $V_{\text {celldis }}$ is the cell discharge voltage in volts, $V_{\text {cellch }}$ is the charge voltage in volts. Voltage efficiency can be reduced due to internal resistance, activation and concentration overpotential (Skyllas-Kazacos, 2010).

The overall energy efficiency of the cell measures the amount of actual energy (Wh) discharged relative to the amount of energy required to charge the cell (Skyllas-Kazacos, 2010). The overall energy efficiency $\eta_{e}$ can be calculated with the following equation: 


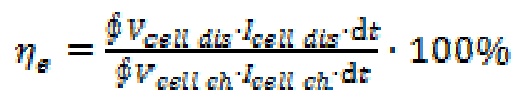

A simpler method to calculate the overall energy efficiency is by simply multiplying coulombic and voltage efficiencies:

$\eta_{e}=\eta_{v} \cdot \eta_{e}$

There are currently several types of electrochemical energy technologies available (SkyllasKazacos, 2010). The electrochemical technologies currently available are the following:

- Electrochemical capacitors;

- Fuel cells;

- Lead-acid battery;

- Nickel-metal hydride batteries;

- Lithium-ion battery;

- Metal-air battery;

- Sodium-Sulphur battery;

- The zero-emissions battery research activity (ZEBRA) battery;

- Flow batteries;

- $\mathrm{Zn} / \mathrm{Br}$ battery;

- All-vanadium redox battery; and

- Vanadium bromide redox battery (G2 V/Br). 


\subsection{Scenario 1-Electric Vehicle}

There are three different level of chargers used to charge electric cars. Level 1 is the standard wall outlet of 120 volts (see Figure 3.5). It is the slowest charge level available, requiring tens of hours to charge $100 \%$ pure electric vehicles and several hours for plug-in hybrid vehicles. Level 2 (see Figure 3.6) is the typical EV plug found in homes and garages capable of charging an EV in 7 hours. The voltage of Level 2 charger is 240 Volts. Most public charging stations are level 2. RV plugs (14-50 kW) are also considered level 2 chargers. Level 3 chargers (see Figure 3.7) are the quickest to fully charge electric vehicles which is also known as DC fast chargers (2020 Guide On How To Charge Electric Car With Charging Stations, 2020). Since the battery on-site stores DC energy, Level 3 Chargers will be used for the electric car scenario.

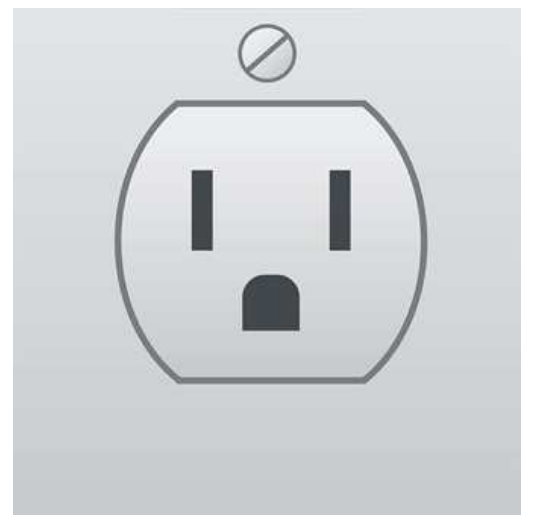

Figure 3.5: Level 1 public charger (2020 Guide On How To Charge Electric Car With Charging Stations, 2020). 


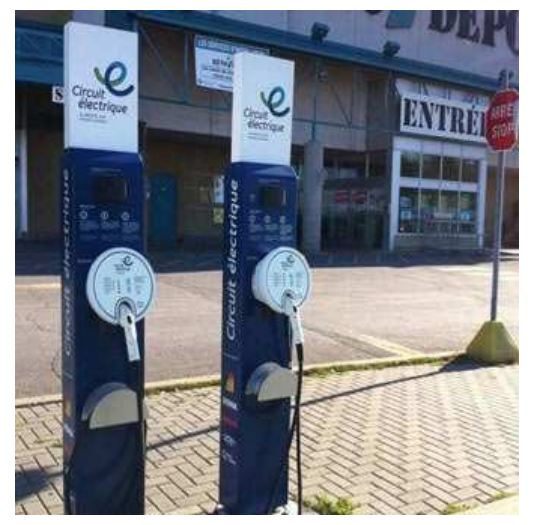

Figure 3.6: Level 2 public charger (2020 Guide On How To Charge Electric Car With Charging Stations, 2020).

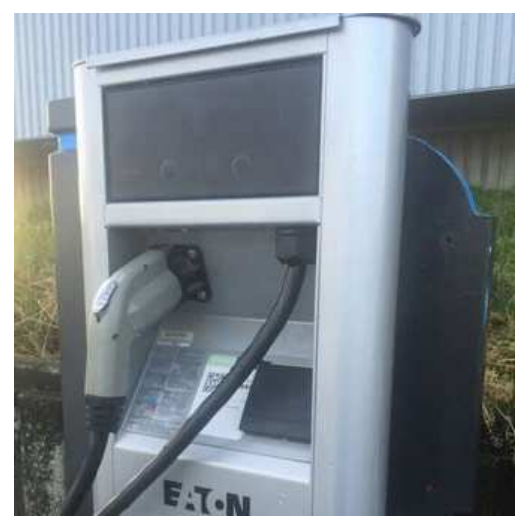

Figure 3.7: Level 3 public charger (2020 Guide On How To Charge Electric Car With Charging Stations, 2020).

\subsubsection{Battery Electric Vehicle:}

In BEVs, the battery is the sole source of energy in the vehicle, powering electric motors through appropriate power management interfaces. They are also called zero emissions vehicles (ZEV). To challenge conventional cars, the battery has to store an amount of energy ensuring a sufficient driving range, and has to be recharged in a relatively short period. Before use, the battery should be recharged from an external power source (Broussely, 2007). 
Unfortunately, a high-energy battery cannot be recharged within a few minutes because the power capability of the battery is not high enough to accept such a very high charging rate. This might be possible with a battery designed for high power, but the battery energy would then be reduced to an unacceptable level, giving too short a driving range. The design of a battery is always a trade-off between energy and power. As a consequence, the driving range with a full charge becomes the crucial parameter, which is directly dependent on the size of the battery (Broussely, 2007).

While the volume of the battery is important for the car design and utilization, as it limits the available useful space, its weight is more critical and is limited by obvious physical considerations. There is a maximum weight for a complete car of a given size that cannot be exceeded otherwise it cannot be safely driven. In addition, energy is needed to move the battery; therefore, the car range is not proportional to the energy stored in battery. As the energy is increased, the weight of the battery quickly becomes intolerable for the vehicle. The most important parameters are therefore the maximum amount of energy that can be stored in a minimum volume and weight; i.e. the energy density $(\mathrm{Wh} / \mathrm{L})$ and the specific energy $(\mathrm{Wh} / \mathrm{kg})$ of the battery (Broussely, 2007). Three tables below show the ranges by volume, weight, energy density, and specific energy.

Table 3.1: Comparison of different BEV batteries for a typical size of $250 \mathrm{~kg}$ (Broussely, 2007).

\begin{tabular}{|l|c|c|c|c|}
\hline \multicolumn{1}{|c|}{ Technology } & Pb Acid & NiCd & NiMH & Li Ion \\
\hline Vehicle curb weight & \multicolumn{4}{|c|}{$1200 \mathrm{~kg}$} \\
\hline Battery weight allocation (typ.) & \multicolumn{4}{c|}{$250 \mathrm{~kg}$} \\
\hline Battery structure, cooling etc. & \multicolumn{4}{c|}{$55 \mathrm{~kg}$} \\
\hline Module weight allocation & \multicolumn{4}{|c|}{$195 \mathrm{~kg}$} \\
\hline Energy density (module) & $33 \mathrm{Wh} / \mathrm{kg}$ & $45 \mathrm{Wh} / \mathrm{kg}$ & $70 \mathrm{Wh} / \mathrm{kg}$ & $120 \mathrm{Wh} / \mathrm{kg}$ \\
\hline Onboard energy & $6.4 \mathrm{kWh}$ & $8.8 \mathrm{kWh}$ & $13.0 \mathrm{kWh}$ & $23.4 \mathrm{kWh}$ \\
\hline Calc. range @120Wh/ton/km & $53 \mathrm{~km}$ & $73 \mathrm{~km}$ & $114 \mathrm{~km}$ & $195 \mathrm{~km}$ \\
\hline
\end{tabular}


Table 3.2: Comparison of different BEV batteries for a typical size of $200 \mathrm{~L}$ (Broussley, 2007).

\begin{tabular}{|l|c|c|c|c|}
\hline \multicolumn{1}{|c|}{ Technology } & Pb Acid & NiCd & NiMH & Li lon \\
\hline Battery volume allocation (typ.) & \multicolumn{4}{|c|}{$200 \mathrm{~L}$} \\
\hline Battery structure, cooling etc. & \multicolumn{4}{|c|}{$70 \mathrm{~L}$} \\
\hline Module volume allocation & \multicolumn{4}{|c|}{$130 \mathrm{~L}$} \\
\hline Volumetric Energy (module) & $75 \mathrm{Wh} / \mathrm{L}$ & $80 \mathrm{Wh} / \mathrm{L}$ & $160 \mathrm{Wh} / \mathrm{L}$ & $190 \mathrm{Wh} / \mathrm{L}$ \\
\hline Onboard energy & $9.8 \mathrm{kWh}$ & $10.4 \mathrm{kWh}$ & $20.8 \mathrm{kWh}$ & $24.7 \mathrm{kWh}$ \\
\hline Range @120Wh/ton/km & $81 \mathrm{~km}$ & $87 \mathrm{~km}$ & $173 \mathrm{~km}$ & $206 \mathrm{~km}$ \\
\hline
\end{tabular}

Table 3.3: Comparison of different BEV batteries for a typical size of $250 \mathrm{~kg}$ (Broussley, 2007).

\begin{tabular}{|l|c|c|c|c|}
\hline \multicolumn{1}{|c|}{ Technology } & Pb Acid & NiCd & NiMH & Li Ion \\
\hline Vehicle curb weight & \multicolumn{4}{|c|}{$1200 \mathrm{~kg}$} \\
\hline Battery weight allocation (typ.) & \multicolumn{4}{|c|}{$250 \mathrm{~kg}$} \\
\hline Battery structure, cooling etc. & \multicolumn{4}{|c|}{$55 \mathrm{~kg}$} \\
\hline Module weight allocation & \multicolumn{4}{|c|}{$195 \mathrm{~kg}$} \\
\hline Power density (module) & $75 \mathrm{~W} / \mathrm{kg}$ & $120 \mathrm{~W} / \mathrm{kg}$ & $170 \mathrm{~W} / \mathrm{kg}$ & $370 \mathrm{~W} / \mathrm{kg}$ \\
\hline Battery Power & $15 \mathrm{~kW}$ & $24 \mathrm{~kW}$ & $33 \mathrm{~kW}$ & $72 \mathrm{~kW}$ \\
\hline
\end{tabular}

\subsubsection{Plug-in Hybrid Electric Vehicle:}

Hybridization provides a pathway to mitigating the emissions and the IC engine's inefficiency by providing energy pathways in series and in parallel to run the IC engine in a high efficiency mode and to maximize the fuel economy. The main advantages of a PHEV compared to an ICEV are the elimination of idling losses, use of braking energy recovery systems, efficient and optimized energy management, and use of downsized and more efficient IC engines. These advantages can double the fuel economy compared to the traditional ICEVs. In general, the IC engine is very inefficient at low torque across the speed range and hits peak efficiency at medium-to-high torques and medium speeds. Idling operation occurs when the engine is generating no motive power, and can result in inefficient operation over the drive cycle. A typical IC engine operates at several hundred revolutions per minute (rpm) while idling. The conventional sparking ignition (SI) IC engine is based on the Otto cycle. The Otto cycle consists of four strokes (intake, compression, expansion, and exhaust). The mixture of fuel and air are 
ignited by a spark to release the energy that provides the power to move the vehicle. In general, IC engines are most efficient at medium-to-high torques and medium speeds, even though during most of the driving cycle, especially in city settings, IC engines operate at low torque and low speeds, resulting in inefficient energy conversion (Hayes, 2018).

Hybridizing the powertrain enables the engine to operate closer to maximum efficiency, in order to minimize emissions and fuel consumption, while operating over the full speed range required for vehicle propulsion. The peak torque available for a $1.5 \mathrm{~L}$ Atkinson cycle gasoline engine is relatively flat over the speed range and increases from $77 \mathrm{Nm}$ at $1000 \mathrm{rpm}$ to $102 \mathrm{Nm}$ at $4000 \mathrm{rpm}$. The peak efficiency varies between about $36 \%$ to $38 \%$ at peak torque over the speed range (Hayes, 2018).

\subsection{Scenario 2- Hydrogen Fuel Cell Car}

\subsubsection{Electrolysis}

Electrolysis is the process in which hydrogen is produced by splitting up hydrogen and oxygen from water (Huggins, 2016). The electrolysis of water occurs by imposing a voltage between two electrodes within the water that exceeds its thermodynamic stability range (Huggins, 2016). The equilibrium (zero current) cell voltage $E_{\text {emf }}{ }^{0}$ required to decompose water can be found the standard Gibbs free energy of the formation of water, $\Delta G_{f}^{0}$, a thermodynamic quantity (Huggins, 2016).

In standard conditions ( $298 \mathrm{~K}$ or $25^{\circ} \mathrm{C}$ and 1 bar or $\left.1 \mathrm{~atm}\right)$, the water splitting reaction is

as follows (Huggins, 2016 and Gandia, 2013):

$$
\mathrm{H}_{2} \mathrm{O}_{(\mathrm{g})} \rightarrow \mathrm{H}_{2(\mathrm{~g})}+\frac{1}{2} \mathrm{O}_{2(g)}
$$


Assuming the chemical reaction occurs alongside a reversible path under isothermal conditions (Gandia, 2013):

$\Delta G(T)=\Delta H(T)-T \Delta S(T)$

Where $\Delta H(T)$ is:

- The enthalpy change associated with the above reaction in $\mathrm{J} / \mathrm{mol}$;

- Positive up to $\approx 2250^{\circ} \mathrm{C}$ (water splitting reaction is endothermic); and

- The total amount of energy that must be supplied to the electrolysis cell to dissociate water into $\mathrm{H}_{2}$ and $\mathrm{O}_{2}$ (Gandi, 2013);

Where $\Delta S(T)$ is:

- The entropy change and the units are $\mathrm{J} /(\mathrm{mol}-\mathrm{K})$;

- $\quad T$ in $\mathrm{K}$ is the absolute temperature; and

- A positive value because 1 mole of water dissociates into 1.5 moles of gases (Gandia, 2013).

Where $\Delta G(T)$ is:

- The Gibbs free energy change and the units are $\mathrm{kJ} / \mathrm{mol}$;

- Positive from a non-spontaneous process up to $\approx 2250^{\circ} \mathrm{C}$ because over this temperature range, the enthalpy term is predominant over entropic change; and

- The amount of electricity that must be supplied to the electrolysis cell in addition to the $T \Delta S(T)$ amount of heat to dissociate water (Gandia, 2013) 
At $25^{\circ} \mathrm{C}$ :

$\Delta G^{0}=237.23 \mathrm{~kJ} / \mathrm{mol}\left(2.94 \mathrm{kWh} / \mathrm{Nm}^{3}\right)$

$\Delta H^{0}=241.81 \mathrm{~kJ} / \mathrm{mol}\left(3.54 \mathrm{kWh} / \mathrm{Nm}^{3}\right)$

$\Delta S^{0}=163.09 \mathrm{~kJ} /(\mathrm{mol}-\mathrm{K})$

The electrical work required for the electrolysis of 1 mole of water in standard condition is:

$\Delta G^{0}=n \cdot F \cdot E^{0}$

Making the equation for the standard thermodynamic voltage:

$E^{0}=\frac{\Delta G^{d}}{n \cdot F}$

Where:

- $n=2$, since there are two electrons; and

- $\quad F=96,485.3 \mathrm{C} / \mathrm{mol}$

Standard thermodynamic Voltage at $25^{\circ} \mathrm{C}$ :

$E^{0}=\frac{237.23 \frac{\mathrm{kJ}}{\mathrm{mol}} \cdot \frac{1000 \mathrm{~J}}{1 \mathrm{~kJ}}}{2 \cdot 96,485.3 \frac{\mathrm{C}}{\mathrm{mol}}}=1.299 \mathrm{~V}$

That means that the voltage needed to exceed the stability range of liquid water at $25^{\circ} \mathrm{C}$ is 1.299

V. It is also possible to define another electrolysis voltage (Gandia, 2013): 
$E_{T N}(T)=\frac{\Delta H(T)}{n \cdot F}$

which is the voltage required for water electrolysis to occur at constant temperature, without exchange of heat in the surroundings (Gandia, 2013).

At temperature less than $100^{\circ} \mathrm{C}, \mathrm{E}_{\mathrm{TN}} \approx 1.48 \mathrm{~V}$ and depends slightly upon pressure. When a cell voltage applied to the cell is less than the standard emf of the cell, nothing occurs due to insufficient energy supplied to the cell to perform the non-instantaneous reaction (Gandia, 2013).

When a cell voltage, that is greater than the standard emf of the cell and yet greater than the thermoneutral voltage, electrolysis is possible, but requires heat from the surroundings. Without heat supplied, the electrolysis cell temperature will decrease. At thermoneutral voltage, water dissociation reaction will take place at constant temperature without any heat absorption from or released to the surroundings decrease (Gandia, 2013). 


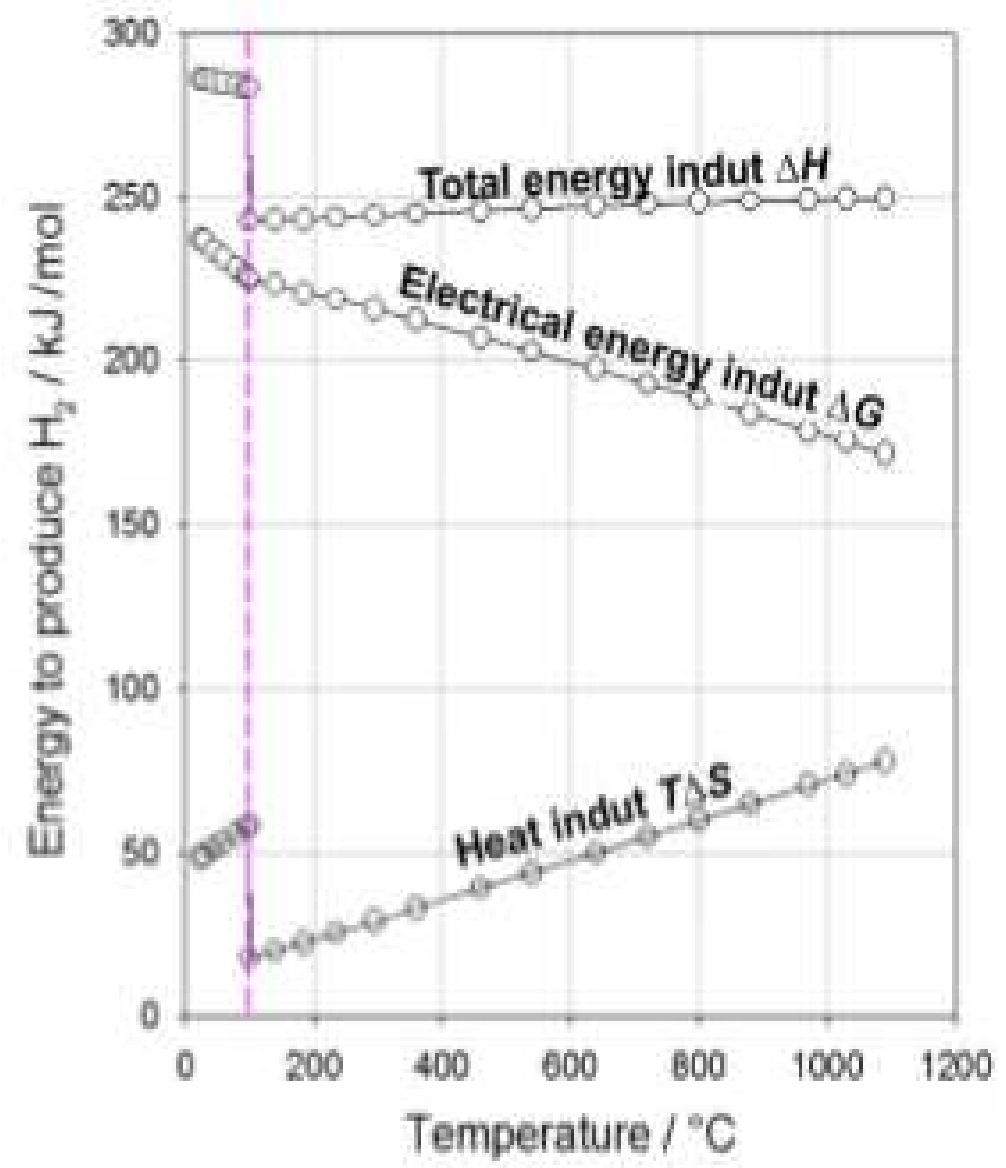

Figure 3.8: Main thermodynamic functions (Millet \& Grigoriev, 2013).

Abrupt changes in total energy indut and heat indut at $373 \mathrm{~K}\left(100^{\circ} \mathrm{C}\right.$ or $\left.212^{\circ} \mathrm{F}\right)$ are due to water phase change from liquid to vapor state. The fraction of electrical energy required for water splitting is defined as the ratio of Gibbs free energy change to the enthalpy change (Gandia and Gurutze Dieguez, 2013):

$\eta_{T D}(T)=\frac{\Delta G(T)}{\Delta H(T)}=\frac{\frac{\Delta G(T)}{n \cdot F}}{\frac{\Delta H(T)}{n \cdot F}}=\frac{E(T)}{E_{T N}(T)}$ 
From what can be seen in Figure 3.8, the enthalpy does not change significantly with operating temperature. The energy consumed during consumed during the electrolysis of the water is defined by the following equation (Gandia and Gurutze Dieguez, 2013):

$$
E_{\text {consumption }}=\frac{\int_{0}^{S t} V_{E} \cdot l_{E} \cdot d t}{\int_{0}^{S E} V_{H_{2}} \cdot d t}
$$

Where $\mathrm{V}_{\mathrm{E}}$ is the electrolysis voltage in volts, $\mathrm{I}_{\mathrm{E}}$ is the electrolysis current in amps, and $\dot{V}_{H 2}$ is the volumetric flow rate in $\mathrm{Nm}^{3} / \mathrm{s}$ between time $\Delta t$ and 0 . To find the electrolysis energy consumption per kilogram, $E_{\text {electrolysis }}$ the following equation is used:

$$
E_{\text {electrolysis }}=E_{\text {consumption }} \cdot\left(\frac{R_{u L} \cdot T_{0}}{M_{H_{2}} \cdot P_{a t m}}\right)
$$

\subsubsection{Liquid Hydrogen Production and Efficiency}

Hydrogen can be stored in liquid phase. Like all gaseous substances, liquid hydrogen occupies less space than in gaseous forms. For this reason, hydrogen is liquefied for storage purposes in many applications. With a density of 70.8 kilograms per cubic meter and at a temperature of 20.4 Kelvin, liquid hydrogen exists between the solid line and the line to the triple point and the critical point at $33.25 \mathrm{~K}$ (Godula-Jopek, 2020). Figure 3.9 shows the curve in which hydrogen is shown to be in liquid phase. 


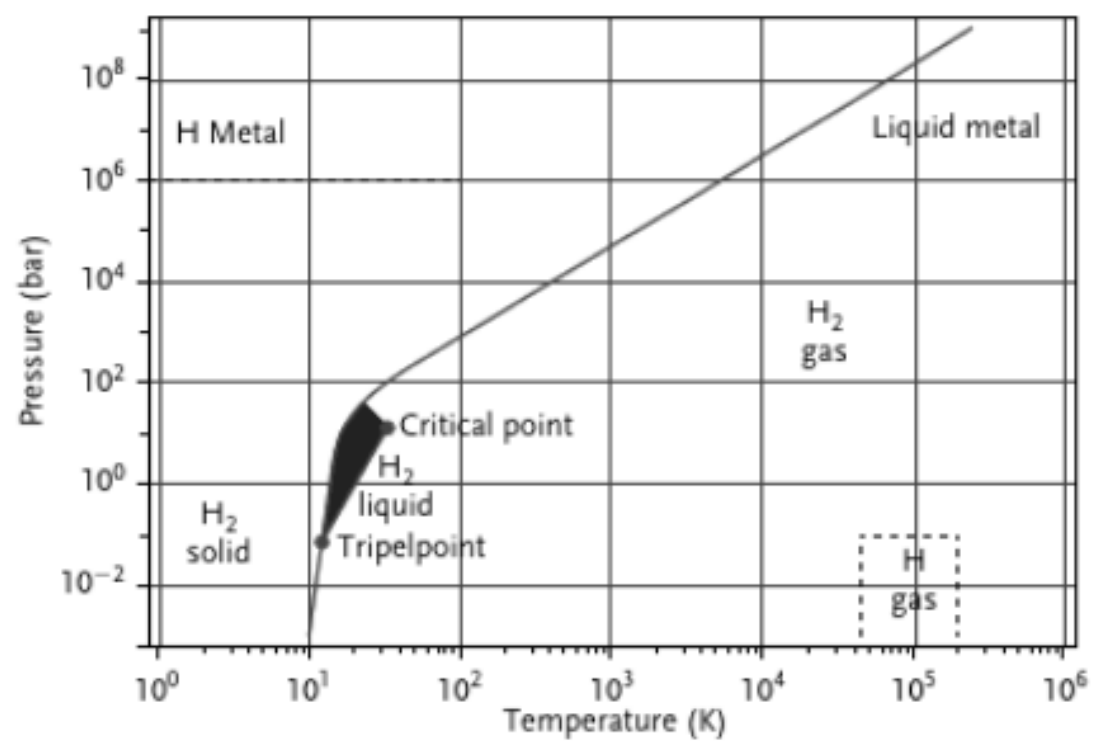

Figure 3.9: Hydrogen phase curve (Godula-Jopek, 2020).

Even though hydrogen requires less space for storage in liquid phase than in gaseous phase, but requires more energy to liquefy than to compress it to the pressure needed for onboard storage (Godula-Jopek, 2020). The energy consumption of liquefaction is calculated using the following equation under the specific operating condition described in this literature (GodulaJopek, 2020):

$E_{\text {liquefier }}=13.382 \times\left(m_{H 2}\right)^{-0.1}$

Where $E_{\text {liquefier }}$ is the specific energy consumed in $\mathrm{kWh} / \mathrm{kg}$ and $m_{\mathrm{H} 2}$ is the $\mathrm{H}_{2}$ mass liquefied per day in kilograms (HVDSAM V3.1, 2020).

The hydrogen is stored in a cryogenic tank for later use. The hydrogen is then pumped through a liquid pump to a high pressure buffer and then an evaporator is used to remove the humidity of the hydrogen, that now is in gas phase after hydrogen is compressed to a higher 
pressure and temperature, where it is stored as hydrogen gas (HVDSAM V3.1, 2014). The specific energy consumed by the liquid pump can be calculated using the following equation:

$E_{L H 2 \text { pump }}=\frac{P_{\text {discharge }}-P_{\text {Suction }}}{\rho_{\mathrm{LHz}} \times \eta_{\mathrm{LHz}} \text { pump } \times \eta_{\mathrm{LHz}} \text { metor }}$

where $\mathrm{e}_{\mathrm{LH} 2 \text { input }}$ is the liquid pump specific energy consumption in $\mathrm{kWh} / \mathrm{kg}, P_{\text {discharge }}$ is the pump discharge pressure in pascals, $P_{\text {suction }}$ is the pump suction pressure in pascals, $\rho_{L H 2}$ is the liquid hydrogen density in $\mathrm{kg} / \mathrm{m}^{3}, \eta_{L H 2}$ pump is the liquid pump efficiency, and $\eta_{\mathrm{LH} 2 \text { motor }}$ is the pump motor efficiency.

\subsubsection{Compressed Hydrogen:}

Hydrogen can also be compressed instead of liquefied to save the energy required to turn hydrogen into liquid, however, hydrogen occupies more space in gaseous phase (Godula-Jopek, 2020). The specific energy consumed by the hydrogen compressor can be calculated using the following equation (HDSAM, 2014):

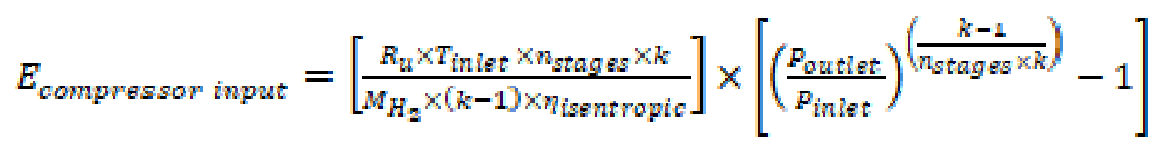

Where $E_{\text {compressor input }}$ is the specific energy consumed by the compressor in $\mathrm{kWh} / \mathrm{kg}, T_{\text {inlet }}$ is the hydrogen inlet temperature in kelvin, $\mathrm{k}$ is the $\mathrm{c}_{\mathrm{p}} / \mathrm{c}_{\mathrm{v}}$ ratio, $\mathrm{n}$ is the number of stages in the compressor, $\eta_{\text {isentropic }}$ is the isentropic efficiency, $P_{\text {outlet }}$ is the compressor pressure outlet in bars, and $P_{\text {inlet }}$ pressure in bars (HDSAM, 2014). 


\subsubsection{Hydrogen Dispenser Pre-Chiller}

The pre-chiller is used to cool the hydrogen to $-40^{\circ} \mathrm{C}$, when the fuel cell car hydrogen tank is being filled with hydrogen (Elgowainy, 2016). The equation used to calculate the cooling load of the pre-chiller is the following:

$E_{\text {cooling lond }}=h_{\text {iwput }}-h_{\text {output }}$

where $E_{\text {cooling load }}$ is the specific cooling load of the pre-chiller in $\mathrm{kWh} / \mathrm{kg}$. Based on the specific cooling load and the coefficient of performance (COP) of the chiller, the electric specific work done by the chiller, $E_{\text {chiller }}$, can be calculated using the following equation (Elgowainy, 2016):

$E_{\text {chiller }}=\frac{E_{\text {woplinglade }}}{\text { copeniller }}$

\subsubsection{Hydrogen Used to Power Fuel Cell Cars}

Since the fuel cell reaction is the opposite of the electrolysis, reaction, equation 3.43 can be inverted, resulting in the following equation:

$\eta_{f w e l \text { cent }}=\frac{E_{f u e l ~ a e l l}}{H H V_{H z}} \times 100 \%$

Where $\eta_{\text {fuel cell }}$ is hydrogen fuel cell efficiency in percent and $E_{\text {fuel cell }}$ is the hydrogen fuel cell specific energy output in kWh/kg (Harrison, Remick, and Martin, 2010).

Wind turbine generates energy, which is used to electrolyze water to hydrogen through electrolysis process, which splits water into hydrogen and oxygen. The generated hydrogen is compressed, stored in large tank, and then used to fill the tank in hydrogen fuel cell powered car. 
In this scenario, the energy consumption of the electrolyser, compressor, chiller, and HHV of the $\mathrm{H}_{2}$ in the fuel cell are taken into consideration.

\subsection{Identify the most attractive}

What determines which scenario is more attractive is how much useful energy is left out of the energy required to either produce the charge a BEV or produce hydrogen to power a FCEV. Bosel, a fuel cell consultant for the European Fuel Cell Forum, has made such calculations in a 2006 publication (Bosel, 2006). Figure 3.10 shows how much useful energy is left in form of electricity for BEV and hydrogen for FCEV. As shown in Figure 3.10, out of $100 \mathrm{kWh}$ electrical power from the grid, $23 \mathrm{kWh}$ are available to power a FCEV with compressed hydrogen, 19 $\mathrm{kWh}$ are available to power a FCEV with liquefied hydrogen, and $69 \mathrm{kWh}$ are available to power a BEV. Factors taken into consideration in calculating the efficiency of powering a FCEV with compressed hydrogen are: conversion from AC to DC, electrolysis, compression, transport/transfer, fuel cell, and fuel cell vehicle with regenerative braking. Electric charging has a total efficiency of $69 \%$ Scenario 1 is more attractive. 


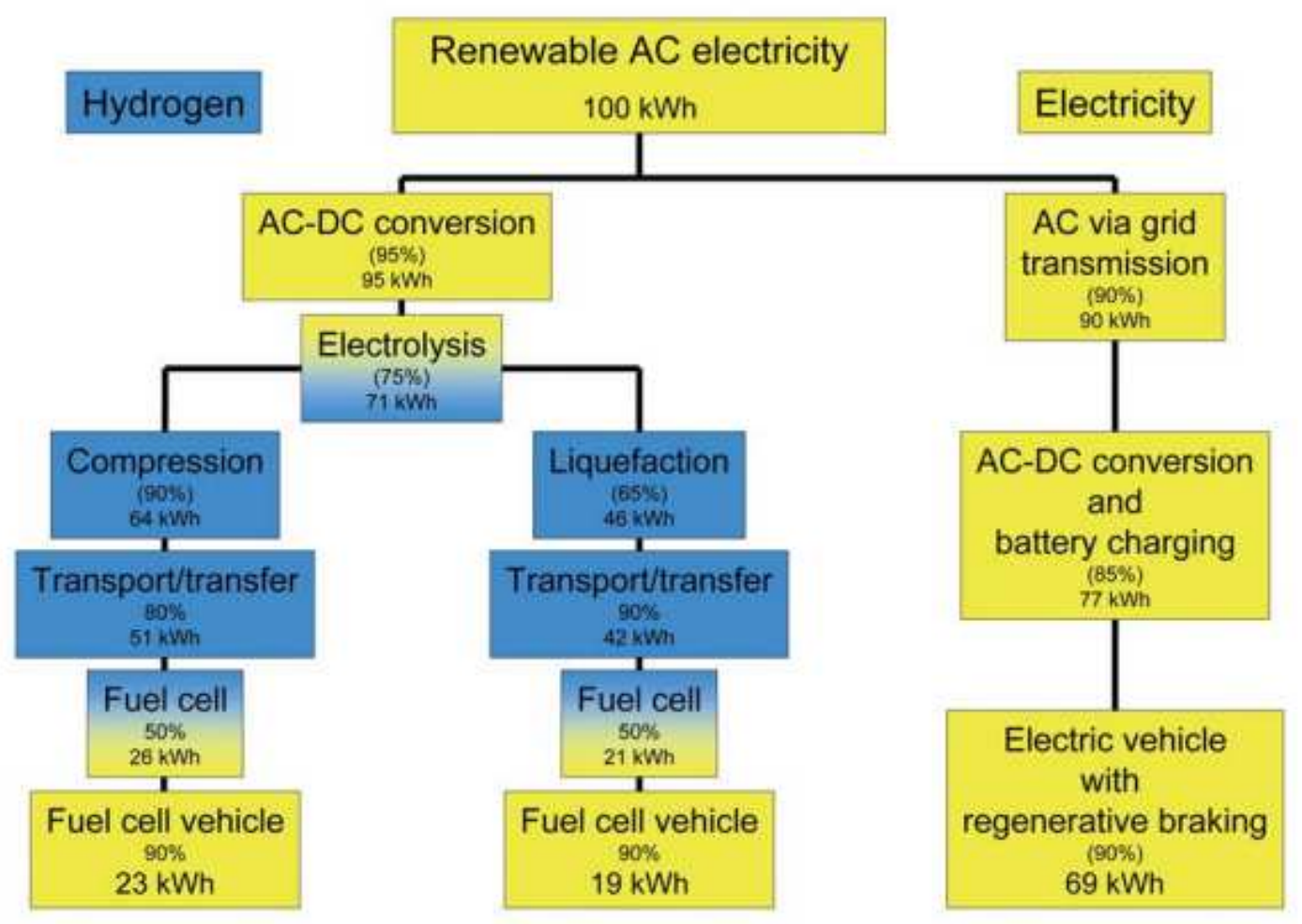

Figure 3.10: Use transport energy derived from renewable electricity to power BEV and FCEV (Bossel, 2006). 


\section{Collection of Data for Model Development}

\subsection{Wind Turbine Data}

The wind turbine power data in Table 4.1 has been collected and will be used for the calculations: the rated turbine power, wind turbine rotor diameter, the cut-in wind speed, rated wind speed, and cut-out wind speed.

Table 4.1: Wind turbine data obtained from

https://www.thewindpower.net/turbine_en_561_mitsubishi_mwt-95.php.

\begin{tabular}{cc}
\hline Parameters & Values \\
Rated Power & $2.4 \mathrm{MW}$ \\
Rotor Diameter & $95 \mathrm{~m}$ \\
Cut-in wind speed & $3.5 \mathrm{~m} / \mathrm{s}$ \\
Rated wind speed & $12 \mathrm{~m} / \mathrm{s}$ \\
Cut-out wind speed & $25 \mathrm{~m} / \mathrm{s}$ \\
\hline
\end{tabular}

The rotor winding resistance and the nominal slip will be calculated based on the power converter current, resistance. In United States, the grid frequency is assumed to be $60 \mathrm{~Hz}$. By combining equations 3.9 and 3.11 and using the minimum possible rotor slip of - 0.3 (Wu, 2011), the mechanical rotor power can be calculated by combining equations 3.9 and 3.11 from Chapter 3:

$$
P_{\text {mech } r \text { rotor }}=P_{\text {mech }} \cdot\left(\frac{s}{1-s}\right)
$$

The mechanical power and the slip have negative signs because the DFIG is assumed to be generating power, therefore on generating mode, making the slip and the turbine power negative as shown on Figure 4.1 (Wu, Lang, Zargari, and Kouro, 2011). 


\begin{tabular}{|c|c|c|c|c|}
\hline Connection & 0 & $\stackrel{\omega_{m}}{\frown}$ & \multicolumn{2}{|c|}{$\begin{array}{l}\text { Mechanical load } \\
\text { or wind turbine }\end{array}$} \\
\hline \multirow[t]{2}{*}{ Phasor diagram } & \multirow{2}{*}{\multicolumn{2}{|c|}{$\begin{array}{c}P_{s}<0 \\
\text { Power Flow: } \\
\text { Machine } \rightarrow \text { Grid } \\
\text { (Generating mode) }\end{array}$}} & \multicolumn{2}{|r|}{$\bar{V}_{s}$} \\
\hline & & & \multicolumn{2}{|c|}{$\begin{array}{c}P_{s}>0 \\
\text { Power Flow: } \\
\text { Grid } \rightarrow \text { Machine } \\
\text { (Motoring mode) }\end{array}$} \\
\hline Operating mode & \multicolumn{2}{|c|}{ Generating mode } & \multicolumn{2}{|c|}{ Motoring mode } \\
\hline Stator power & \multicolumn{2}{|c|}{$P_{s}=3 V_{s} I_{s} \cos \varphi_{s}<0$} & \multicolumn{2}{|c|}{$P_{s}=3 V_{s} I_{s} \cos \varphi_{s}>0$} \\
\hline $\begin{array}{c}\text { Slip and torque } \\
\text { (normal operation) }\end{array}$ & $s<0$ & $T_{m}<0, T_{e}<0$ & $\mathrm{~s}>0$ & $T_{m}>0, T_{e}>0$ \\
\hline $\begin{array}{l}\text { Power factor angle } \\
\text { and power factor }\end{array}$ & $90^{\circ} \leq \varphi_{s}<180^{\circ}$ & $-1 \leq P F_{s} \leq 0$ & $0 \leq \varphi_{s}<90^{\circ}$ & $0 \leq P F_{s} \leq 1$ \\
\hline
\end{tabular}

Figure 4.1: Summary for induction machine operating at generating and motoring modes $(\mathrm{Wu}$, 2011).

By using equation 4.1, $P_{\text {mech, rotor }}$ is found to be $-553.85 \mathrm{~kW}$.

\subsection{Power Converters}

In order to convert $\mathrm{AC}$ power from the turbine to the generator, and the generator is a DFIG, two power converters (one for the rotor side and the other for the grid side). The grid side power converter will not be used since only energy obtained from the wind turbine will be considered. Three IGBT modules CM450DXL-34SA were selected so each is converted to one phase of the AC rotor side. The fraction of the DFIG generated energy that goes to the battery is three thirteenths of the overall mechanical power when the rotor to stator slip is at its maximum, $-0.3(\mathrm{Wu}, 2011)$. Table 4.2 shows the data used to calculate the IGBT module efficiency. For the rotor side, since the AC voltage rms will be assumed to be $690 \mathrm{rms}$ and for the stator side, a power converter with a voltage rating of $1700 \mathrm{~V}$ and the P-N bus voltage of around $1200 \mathrm{~V}$ was selected (Mitsubishi Power Module, 2020). 
Table 4.2: Data on rotor side power converter used to calculate power converter losses on the rotor side (CM450DXL-34SA, 2014).

\begin{tabular}{|c|c|c|c|}
\hline Symbol & Item & Rating & Unit \\
\hline $\mathrm{I}_{\mathrm{c}}$ & Collector Current & 450 & $\mathrm{~A}$ \\
\hline $\mathrm{V}_{\mathrm{DC}}$ & Output DC Voltage & 1200 & $\mathrm{~V}$ \\
\hline $\mathrm{P}_{\text {diss }}$ & Total power dissipated & 4410 & $\mathrm{~W}$ \\
\hline
\end{tabular}

By combining equations 3.12 and 3.13 from Section 3, the following equation is used to calculate the DFIG rotor side efficiency:

$\eta_{\text {rotor }}=\frac{I_{C} \times V_{D C}+P_{\text {diss }}}{P_{\text {mech } r \text { rotor }}} \times 100 \%$

By using the data from Table 4.2 and using the $P_{\text {mech,rotor }}$ obtained from Section 4.1 (converted from kilowatts to watts, the DFIG rotor efficiency can be calculated:

$$
\eta_{\text {rotor }}=\frac{-450 \mathrm{~A} \times 1200 \mathrm{~V}-4410 \mathrm{~W}}{-553846.2 \mathrm{~W}} \times 100 \%=98.30 \%
$$

The ACDC converter efficiency also needs to be calculated, which can be done by combining equations 3.19 and 3.20 from Section 3:

$\eta_{A C D C}=\frac{I_{C} \cdot V_{D C}}{I_{C} \cdot V_{D C}+P_{d i s s}} \times 100 \%$

and using data from Table 4.2:

$$
\eta_{A C D C}=\frac{450 \mathrm{~A} \times 1200 \mathrm{~A}}{450 \mathrm{~A} \times 1200 \mathrm{~A}+4410 \mathrm{~W}} \times 100 \%=99.19 \%
$$




\subsection{Scenario 1: Charging Cars Directly from the Community Giant Battery}

\subsubsection{Lithium-Ion as Battery of Choice}

Lithium-Ion has been chosen as the battery used to simulate storage of wind-generated energy due to its high energy density (Sumper, 2016). Out of several lithium-ion battery technologies developed so far, lithium-ion battery with nickel manganese colbalt cathode $\left(\mathrm{LiNi}_{\mathrm{x}} \mathrm{Mn}_{\mathrm{y}} \mathrm{Co}_{1-\mathrm{x}-\mathrm{y}}\right)$ has been selected as the giant battery for the wind farm due to having the highest energy density of all of lithium ion battery technologies available as shown in Table 4.3 (Julien, 2016). The lithium-ion battery energy efficiency $\eta_{\text {battery }}$ is assumed to be $90 \%$ based on Figure 4.2 (Valøen and Shoesmith, 2007).

Table 4.3: Lithium ion battery technologies developed so far (Julien, 2016).

\begin{tabular}{|c|c|c|c|c|}
\hline Acronym & Cathode & Anode & $\begin{array}{c}\text { Cell Voltage } \\
\text { (V) }\end{array}$ & $\begin{array}{c}\text { Energy Density } \\
(\mathrm{Wh} / \mathrm{kg})\end{array}$ \\
\hline $\mathrm{LCO}$ & $\mathrm{LiCoO}_{4}$ & Graphite & $3.7-3.9$ & 140 \\
\hline LNO & $\mathrm{LiNiO}_{4}$ & Graphite & 3.6 & 150 \\
\hline NCA & $\mathrm{LiNi}_{0.8} \mathrm{CO}_{0.15} \mathrm{Al}_{0.05} \mathrm{O}_{2}$ & Graphite & 3.65 & 130 \\
\hline NMC & $\mathrm{LiNi}_{\mathrm{x}} \mathrm{Mn}_{\mathrm{y}} \mathrm{Co}_{1-\mathrm{x}-\mathrm{y}}$ & Graphite & $3.8-4.0$ & 170 \\
\hline LMO & $\mathrm{LiMn}_{2} \mathrm{O}_{4}$ & Graphite & 4.0 & 120 \\
\hline LMN & $\mathrm{LiNi}_{0.5} \mathrm{Mn}_{1.5} \mathrm{O}_{4}$ & Graphite & 4.8 & 140 \\
\hline LFP & $\mathrm{LiFeO}_{4}$ & $\mathrm{Li}_{4} \mathrm{Ti}_{5} \mathrm{O}_{12}$ & $2.3-2.5$ & 100 \\
\hline
\end{tabular}




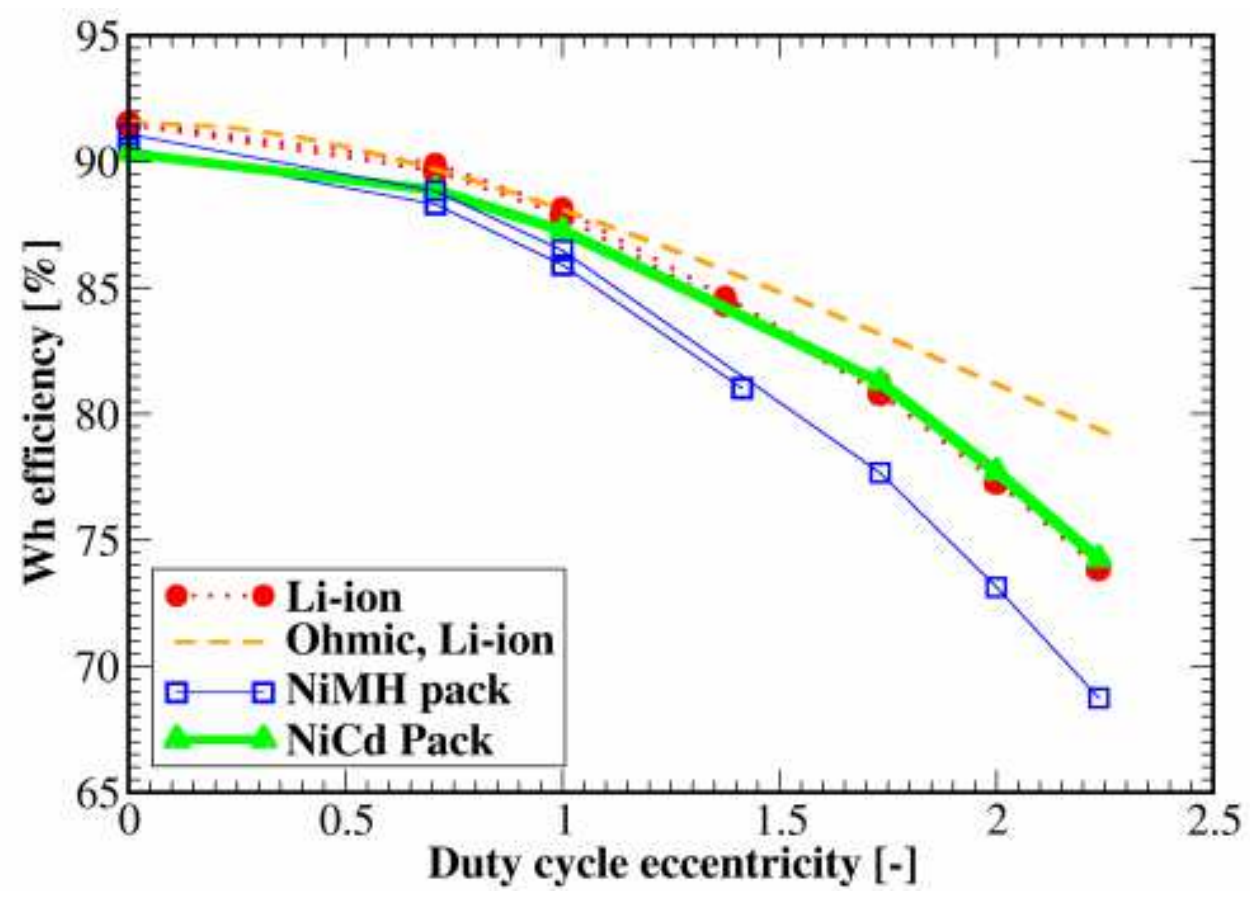

Figure 4.2: Measured round trip charge and discharge efficiencies as function of duty cycle eccentricity (Valøen and Shoesmith, 2007).

\subsubsection{Charging Station Connector}

To study the efficiency of the use of the electric energy stored directly from the wind turbine, the assumption will be made that the charging station is located at the wind farm. Since the car would be directly charged from the big battery storage at the windfarm, assume that DC Fast Charge will be used. Level 3 Connectors: The connector type to be installed to the Windfarm Charging Station is shown in Figure 4.3: 


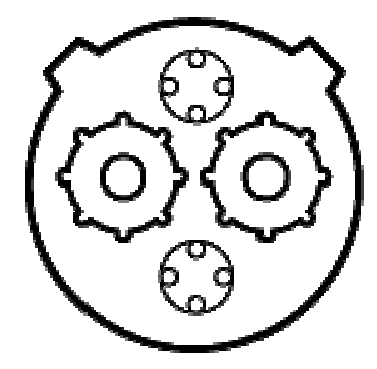

Figure 4.3: CHAdeMO Connector (2020 Guide On How To Charge Electric Car With Charging Stations, 2020).

Since CHAdeMO is the only connector type that can be used by a Tesla model and other models, this connector will be used for the simulation. Most chademo efficiencies are around $92 \%$ and their power output is around $50 \mathrm{~kW}$ (Trentadue, 2018).

\subsubsection{BEV Charging Port}

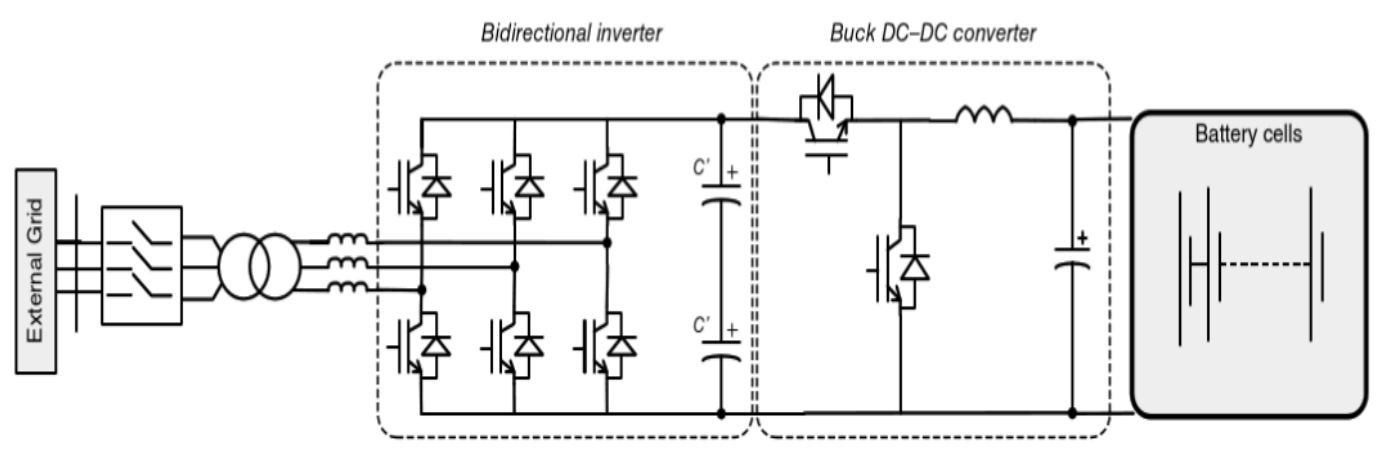

Figure 4.4: Charging vehicle seen as a storage capability (Sumper, 2016).

When being charged at the charging station (wind farm in this case), the electric vehicle can be seen by the operator at the station as a storage capability. Figure 4.4 shows three-phase AC energy being taken from an external grid or DFIG, going through a bidirectional inverter, AC current is converted to DC current. Voltage decreases as well. Afterwards, the now DC 
energy goes through a buck DC-DC converter, where voltage is reduced, so the voltage matches the BEV battery pack (Sumper, 2016). The charging port to be used for this research has the data in Table 4.4:

Table 4.4: Charging port specification (Trentadue, 2018).

\begin{tabular}{|c|c|}
\hline Measurements & Values and Units \\
\hline Voltage: & $600-900 \mathrm{~V}$ \\
\hline Current: & $90 \mathrm{~A}$ \\
\hline Max Current: & $125 \mathrm{~A}$ \\
\hline Power: & $50 \mathrm{~kW}$ \\
\hline Efficiency: & $>92 \%$ \\
\hline
\end{tabular}

$$
\eta_{\text {charging port }}=\frac{P_{\text {output port }}}{I_{\text {port }} \cdot V_{\text {port }}} \times 100 \%=\frac{50 \mathrm{~kW}}{90 \mathrm{~A} \times 600 \mathrm{~V}} \times \frac{1000 \mathrm{~W}}{1 \mathrm{~kW}} \times 100 \%=92.59 \%
$$

Since the nominal output power divided by the product of the minimum voltage required for the charging port and the nominal charging port current and resulted in an efficiency greater than $92 \%$, so there is no need to use a higher voltage.

\subsubsection{Buck Converter Between Battery and Charging Port}

Since the voltage at the DC fast charging station is 600 volts while the voltage at the battery bank is around 1200 volts, a buck converter is necessary to step down the voltage. Since the ACDC IGBT converter efficiency $\eta_{A C D C}$ was found to be $99.19 \%$, the DCDC buck converter $\eta_{D C D C}$ will be assumed to be $99.5 \%$. 
Table 4.5: Values that will be used based on assumptions made based on duty-cycle eccentricity and AC/DC converter calculated efficiency.

\begin{tabular}{|c|c|c|}
\hline Efficiency & Assumed Value & Basis \\
\hline Battery Bank & $90 \%$ & $\begin{array}{r}\text { There might be some eccentricity in the duty } \\
\text { cycle (see Figure 4.2). }\end{array}$ \\
\hline Buck Converter & $99.5 \%$ & ACDC Converter Efficiency is 99.19\%. \\
\hline
\end{tabular}

\subsubsection{BEV Battery Packs}

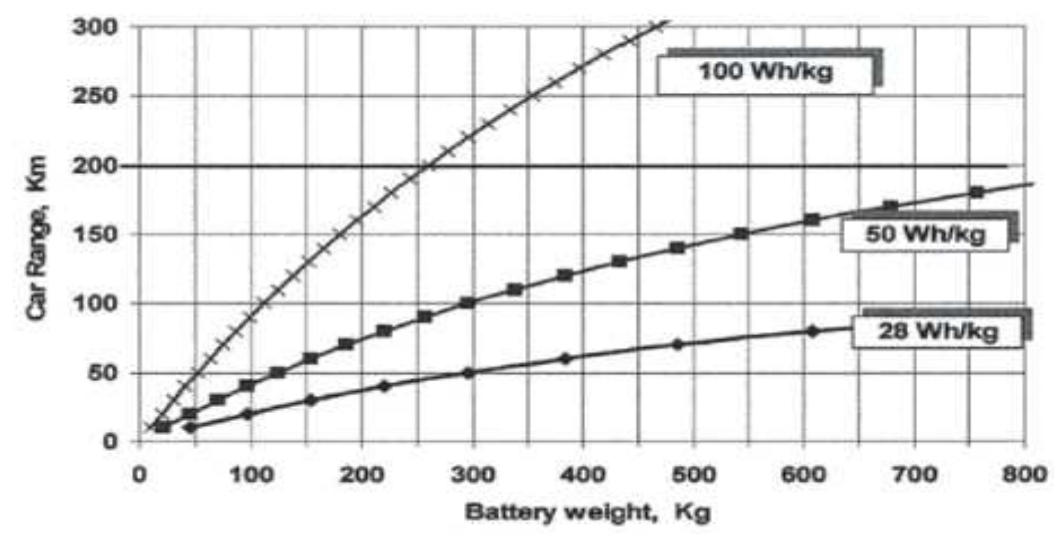

Figure 4.5: Corresponding weights of several batteries of different specific energy (Broussely, 2007).

Battery packs are where the energy charged from the port is stored (How do All-Electric Cars Work?, 2018). For this reason, the type of material the batteries are made of is important.

Figure 4.5 shows the car range as a function of the battery weight with curves of varying energy density in $\mathrm{Wh} / \mathrm{kg}$. The greater the energy density, the greater the car range can be. A minimum of about $100 \mathrm{Wh} / \mathrm{kg}$ is mandatory to exceed a $200 \mathrm{~km}$ range. As of today, only lithium-based batteries can achieve this goal today (Broussely, 2007). For this reason, BEV with Lithium-ion batteries will be used in the model. The efficiency of the battery traction $\eta_{\text {battery traction }}$ is the same as the battery bank efficiency $\eta_{\text {battery bank }}$ which is around $90 \%$, based on Figure 4.2. 
Table 4.6 shows the BEV selected for this research. The energy consumption of each car is measured by the amount of $\mathrm{kWh}$ per 100 miles. All BEV have maximum ranges greater than $200 \mathrm{~km}$, with Tesla S 2020 having the greatest distance range (373 miles) and Porsche Taycan Turbo S having the smallest distance range 201 miles, just above 200 miles. Nissan Leaf 2019 is the most recent model (no 2020 model could be found). All of the BEV have more $\mathrm{kWh}$ per 100 miles in city settings than in highway settings, except for the Porsche Taycan Turbo $\mathrm{S}$ that has less kWh per 100 miles in highway settings than in city settings (Fuel Economy Guides, 2019 and 2020).

Table 4.6: BEV operation range data collected (Fuel Economy Guides, 2019 and 2020).

\begin{tabular}{|c|c|c|c|c|c|c|c|}
\hline \multirow{2}{*}{ Make } & \multirow{2}{*}{ Model } & Year & $\begin{array}{c}\text { Distance } \\
\text { Range (miles) }\end{array}$ & $\begin{array}{c}\text { Battery } \\
\text { Range } \\
(\mathrm{kWh})\end{array}$ & \multicolumn{3}{|c|}{$\begin{array}{c}\text { Electrical Energy Consumption, } \\
\mathrm{kWh} / 100 \text { mile }\end{array}$} \\
\cline { 6 - 9 } & & & Combined & City & Highway \\
\hline Tesla & $\mathrm{S}$ & 2020 & 373 & 100 & 30 & 29 & 31 \\
\hline Nissan & Leaf & 2019 & 226 & 62 & 31 & 29 & 35 \\
\hline Chevrolet & Bolt EV & 2020 & 259 & 66 & 30 & 26 & 31 \\
\hline Porsche & $\begin{array}{c}\text { Taycan } \\
\text { Turbo S }\end{array}$ & 2020 & 201 & 93.4 & 50 & 50 & 49 \\
\hline \multicolumn{2}{|c|}{ Average } & & 264.75 & 80.35 & 35.25 & 33.5 & 36.5 \\
\hline
\end{tabular}

\subsection{Scenario 2: Hydrogen as Fuel}

In the second scenario, the electrical energy stored in the big battery is used to split water into hydrogen and oxygen, with hydrogen being either compressed or liquefied. Table 4.7 shows data used to calculate the energy consumed by the electrolysis and the amount of hydrogen produced (Nel Hydrogen, 2020 and HDSAM V 3.1, 2014). 
Table 4.7: Electrolysis data from Nel Hydrogen model M100 (Nel Hydrogen, 2020 and HDSAM V 3.1, 2014).

\begin{tabular}{cccc}
\hline Net Production Rate & $m_{\text {electrolysis }}$ & 222 & $\mathrm{~kg} / 24 \mathrm{~h}$ \\
Model Production & $m_{H 2}$ & 200 & $\mathrm{~kg} / 24 \mathrm{~h}$ \\
Hydrogen Pressure Delivery & $P_{\text {electrolysis }}$ & 30 & $\mathrm{barg}$ \\
Class & Welectrolysis & 0.5 & $\mathrm{MW}$ \\
Average Consumption at stack & $E_{\text {electrolysis }}$ & 50.33 & $\mathrm{kWh} / \mathrm{kg}$ \\
\hline
\end{tabular}

\subsubsection{Compressed Hydrogen}

Hydrogen can be compressed so it takes up less space than it would otherwise if at ambient pressure. Data on compressed hydrogen was obtained from HDSAM and is written in Table 4.8:

Table 4.8: Data obtained from electrolyser from HDSAM (HDSAM3.1, 2014).

\begin{tabular}{|c|c|c|c|}
\hline Parameter & Variable or Symbol & Value & Data \\
\hline Inlet Temperature & $T_{\text {inlet }}$ & 298.15 & $\mathrm{~K}$ \\
\hline Inlet Pressure & $P_{\text {inlet }}$ & 30 & barg \\
\hline Outlet Pressure & $P_{\text {outlet }}$ & 950 & barg \\
\hline Isentropic efficiency & $\eta_{\text {isentropic }}$ & 75 & $\%$ \\
\hline Motor Efficiency & $\eta_{\text {motor }}$ & 96 & $\%$ \\
\hline
\end{tabular}

According to the HDSAM, the maximum compression ratio per stage is 2.1, therefore the number of times that it takes for the compressor to reach 950 barg (bar gauge pressure) or 951.01 bara (bar absolute pressure) which is the outlet pressure of the compressor. Table 4.9 shows the inlet and outlet pressures for each stage. 
Table 4.9: Inlet and outlet pressure at each stage of the compressor.

\begin{tabular}{|c|c|c|c|}
\hline Stage & Inlet Pressure & Outlet Pressure & Greater than 951.01 bara \\
\hline 1 & 31.01 bara & 65.13 bara & No \\
\hline 2 & 65.13 bara & 136.77 bara & No \\
\hline 3 & 136.77 bara & 287.21 bara & No \\
\hline 4 & 287.21 bara & 603.15 bara & No \\
\hline 5 & 603.15 bara & 1266.61 bara & Yes \\
\hline
\end{tabular}

Since only in the fifth stage the compressor reached higher than 950 barg, the compressor has been determined to have five stages. The compressor input value can be calculated:

$E_{\text {compressor input }}$

$$
\begin{aligned}
& =\left(\frac{8.314 \mathrm{~J} /(\mathrm{mol} \cdot \mathrm{K}) \cdot 298.15 \mathrm{~K}}{2 \mathrm{~g} / \mathrm{mol}} \times \frac{1000 \mathrm{~g}}{1 \mathrm{~kg}} \times \frac{1 \mathrm{~W} \cdot \mathrm{h}}{3600 \mathrm{~J}} \times \frac{1 \mathrm{~kW}}{1000 \mathrm{~W}}\right) \times\left(\frac{1.4}{1.4-1}\right) \\
& \times\left(\frac{5}{0.75 \times 0.96}\right) \times\left[\left(\frac{951.01325 \text { bara }}{31.01325 \text { bara }}\right)^{\left(\frac{1.4-1}{5 \cdot 3.4}\right)}-1\right]=1.81 \mathrm{kWh} / \mathrm{kg}
\end{aligned}
$$

\subsubsection{Liquid Hydrogen}

Table 4.10: Data obtained from NIST to calculate the ideal amount of work done on the liquefier (NIST, 2020 and HDSAM V 3.1, 2014).

\begin{tabular}{cccc}
\hline Inlet Temperature & $T_{\text {inlet }}$ & 298.15 & $\mathrm{~K}$ \\
Inlet Pressure & $P_{\text {inlet }}$ & 30 & barg \\
Outlet Temperature & $T_{\text {outlet }}$ & 20.1 & $\mathrm{~K}$ \\
Outlet Pressure & $P_{\text {outlet }}$ & 2 & $\mathrm{barg}$ \\
$\mathrm{H}_{2}$ Mass Liquefied & $m_{\mathrm{H} 2}$ & 200 & $\mathrm{~kg}$ \\
\hline
\end{tabular}


Equation 3.42 and data from Table 4.10 were used to obtain the specific energy consumed by the liquefier. The mass liquefied is the same mass of hydrogen produced by the electrolysis (HDSAM V 3.1, 2014):

$$
E_{\text {liquefier }}=13.382 \times\left(200 \frac{\mathrm{kg}}{\mathrm{day}} \times \frac{1 \mathrm{ton}}{1000 \mathrm{~kg}}\right)^{-0.1}=15.72 \mathrm{kWh} / \mathrm{kg}
$$

The liquid pump data and hydrogen properties are listed in Table 4.11.

Table 4.11: Hydrogen liquid pump data (HDSAM V 3.1, 2014 and NIST, 2020).

\begin{tabular}{cccc}
\hline Inlet Pressure & $\mathrm{P}_{\text {suction }}$ & 2 & barg \\
Outlet Pressure & $\mathrm{P}_{\text {discharge }}$ & 950 & $\mathrm{barg}$ \\
Density & $\rho_{\text {LH2 }}$ & 71.373 & $\mathrm{~kg} / \mathrm{m}^{3}$ \\
Pump Efficiency & $\eta_{\text {LH2 pump }}$ & 75 & $\%$ \\
Motor Efficiency & $\eta_{\text {LH2 motor }}$ & 96 & $\%$ \\
\hline
\end{tabular}

The energy input from the hydrogen liquid pump can be calculated:

$$
E_{L H_{2} \text { pump }}=\frac{95,101,325 \mathrm{~Pa}-3,101,325 \mathrm{~Pa}}{71.373 \mathrm{~kg} / \mathrm{m}^{3} \times 0.75 \times 0.96} \times \frac{1 \mathrm{~kW}}{1000 \mathrm{~W}} \times \frac{1 \mathrm{~h}}{3600 \mathrm{~s}}=0.51 \mathrm{kWh} / \mathrm{kg}
$$

\section{$\underline{\text { 4.4.3 Pre-chiller }}$}

The pre-chiller, which cools down the hydrogen gas before it goes to the fuel cell car can be calculated using equations 3.45 and 3.46 from section 3 and the data collected from the 2016 DOE Lab Review (Elgowainy and Reddi, 2016) shown in Table 4.12:

$$
E_{\text {ohiller }}=\frac{(4574.3 \mathrm{~kJ} / \mathrm{kg}-3407.4 \mathrm{~kJ} / \mathrm{kg})}{1} \times \frac{1 \mathrm{~kW}}{1 \mathrm{~kJ} \cdot \mathrm{s}} \times \frac{1 \mathrm{~h}}{3600 \mathrm{~s}}=0.32 \mathrm{kWh} / \mathrm{kg}
$$


Table 4.12: Hydrogen pre-chiller data obtained from HDSAM and NIST hydrogen table properties.

\begin{tabular}{cccc}
\hline Inlet Pressure & $P_{\text {inlet }}$ & 950 & $\mathrm{barg}$ \\
Inlet Temperature & $T_{\text {inlet }}$ & 298.15 & $\mathrm{~K}$ \\
Inlet Enthalpy & $h_{\text {inlet }}$ & 9.22 & $\mathrm{~kJ} / \mathrm{kg}$ \\
Outlet Pressure & $P_{\text {outlet }}$ & 700 & $\mathrm{barg}$ \\
Outlet Temperature & $T_{\text {outlet }}$ & 233.15 & $\mathrm{~K}$ \\
Outlet Enthalpy & $h_{\text {outlet }}$ & 3407.4 & $\mathrm{~kJ} / \mathrm{kg}$ \\
Chiller COP & $C O P_{\text {chiller }}$ & 1 & \\
\hline
\end{tabular}

\subsubsection{Fuel Cell}

Since fuel cell is the opposite of electrolysis, the $\mathrm{HHV}$ of $\mathrm{H}_{2}$ will be used as the specific energy input $E_{\text {fuel cell }}$ which is $39.4 \mathrm{kWh} / \mathrm{kg}$. Table 4.13 lists the cars selected to have their mileage evaluated. The four fuel cell cars selected are: Toyota Mirai 2019, Honda Clarity Fuel Cell 2020, Hyundai Nexo Limited 2020, and Hyundai Nexo Blue 2020. The four FCEV were selected based on their long-distance range, with all of them above 350 miles.

Table 4.13: Data collected on fuel cell vehicles (Fuel Economy Guides, 2019 and 2020).

\begin{tabular}{|c|c|c|c|c|c|c|}
\hline & & & & \multicolumn{3}{|c|}{ Hydrogen mass consumption per mile, mile/kg } \\
\cline { 5 - 7 } Make & Model & Year & Range & Combined & City & Highway \\
\hline Toyota & Mirai & 2019 & 380 & 66 & 65 & 66 \\
\hline Honda & Clarity Fuel Cell & 2020 & 360 & 66 & 67 & 66 \\
\hline Hyundai & Nexo Limited & 2020 & 354 & 56 & 58 & 53 \\
\hline Hyundai & Nexo Blue & 2020 & 380 & 60 & 64 & 56 \\
\hline \multicolumn{3}{|c|}{ Average } & 368.5 & 62 & 63.5 & 60.25 \\
\hline
\end{tabular}




\section{Methodology}

\subsection{Scenario 1: Electric Cars}

To find the amount of energy consumed from the battery bank, the amount of energy consumed in kilowatt-hour over 100 miles needs to be divided by the overall efficiency. The following equation will be used to calculate the overall electric efficiency:

$\eta_{\text {overall electrie }}=\eta_{\text {rotor }} \times \eta_{A C D C} \times \eta_{\text {battery bank }} \times \eta_{D C D C} \times \eta_{\text {charging port }}$

The energy consumed in kilowatt-hours per 100 miles will be obtained using the following equation:

$E_{\text {overall alectrie }}=\frac{E_{100 \text { milss }}}{\eta_{\text {geverall electric }}} \times 100 \%$

Where $E_{\text {overall electric }}$ is the amount of energy consumed from the battery bank and $E_{100 m i l e s}$ is the energy consumed from car battery over 100 miles. The battery bank energy consumed per 100 miles will be calculated from the $\mathrm{kWh} / \mathrm{kg}$ combined city and highway settings, city settings, and highway settings.

Since the battery consists of constant current up to $80 \%$ SOC and then and slow current drop until $100 \%$ SOC, which can take hours to achieve. For this reason, only the 100 miles worth of charging up to $80 \%$ SOC will be calculated. The battery energy consumed over 100 miles at city, highway, and combined settings will be subtracted from the battery energy available at $80 \%$ SOC using the following equation:

$E_{\text {pre-Charge }}=0.8 \times E_{\text {full charge }}-E_{100 \mathrm{miles}}$ 
Where EPre-charge is the energy available before charging in $\mathrm{KWh}, E_{\text {full }}$ charge is the maximum amount of energy available in the track battery in $\mathrm{kWh}$, and $E_{100 \text { miles }}$ is the amount of energy consumed over 100 miles. The charge availability after driving 100 miles at city, highway, and combined settings will be calculated using the following equation:

$R_{\text {Pre-Charge }}=\frac{E_{\text {Pre-Charge }}}{E_{\text {ful l charge }}} \times 100 \%$

Where $R_{\text {Pre-Charge }}$ is the percentage of the battery available. The amount of time taken to recharge the battery up to $80 \%$ range will be calculated using the following equation:

$t_{\text {charge }}=\frac{E_{18 s \text { milss }}}{50 \mathrm{~kW} \times \eta_{\text {twaction battery }}}$

Where $t_{\text {charge }}$ is the time taken for charging 100 miles worth of energy up to $80 \%$ of the range in minutes.

The following assumptions will be made: the ambient temperature is around $77^{\circ} \mathrm{F}$ (298.15 K) and even if the wind is not blowing at full speed during the day, there is enough energy stored in the battery to charge the cars.

\subsection{Scenario 2: Hydrogen}

To calculate the amount of energy consumed by the hydrogen from the storage, it is necessary to find how much hydrogen is consumed per 100 miles, the following equation will be used:

$\frac{d_{H a}}{1 \mathrm{~kg}}=\frac{100 \mathrm{miles}}{m_{\text {Ha FCEV }}}$ 
Where $d_{H 2}$ is the distance that FCEVs consume one kilogram of $\mathrm{H}_{2}$ gas and $m_{H 2}$ FCEV is the mass of hydrogen consumed over 100 miles. By solving for $\mathrm{m}_{\mathrm{H} 2 \mathrm{FCEV}}$ equation 5.6 becomes:

$$
m_{H 2 F C E V}=\frac{100 \text { miles }}{d_{H n}} \times 1 \mathrm{~kg}
$$

\subsubsection{Liquid Hydrogen}

Table 5.1 lists all of the equipment and the amount of specific energy consumed by each one of them as well as the sum of the energy consumed.

Table 5.1: List of specific energy consumption by different equipment in the liquid hydrogen scenario.

\begin{tabular}{ccccc}
\hline Process & Equipment & Parameter & Value & Unit \\
\hline Electrolysis & PEM Electrolyzer & $E_{\text {electrolysis }}$ & 50.33 & $\mathrm{kWh} / \mathrm{kg}$ \\
Liquefaction & Liquefier & $E_{\text {liquefier }}$ & 15.72 & $\mathrm{kWh} / \mathrm{kg}$ \\
Pumping & Liquid Pump & $E_{\text {LH2 pump }}$ & 0.51 & $\mathrm{kWh} / \mathrm{kg}$ \\
Pre-Chilling & Pre-Chiller & $E_{\text {chiller }}$ & 0.32 & $\mathrm{kWh} / \mathrm{kg}$ \\
Energy Generation & DFIG Rotor Side & $\eta_{\text {rotor }}$ & 0.983 & \\
AC to DC Conversion & ACDC Converter & $\eta_{A C D C}$ & 0.9919 & \\
\hline Total Specific Electrical Energy Input & $E_{\text {LH2 input }}$ & 68.60 & $\mathrm{kWh} / \mathrm{kg}$ \\
\hline
\end{tabular}

The $\mathrm{kWh}$ consumed by the FCEV per $\mathrm{kg}$ of $\mathrm{H}_{2}$ can be calculated using the following equation:

$E_{L H 2 \text { input }}=\frac{E_{\text {electrolysis }}+E_{\text {lipusfaction }}+E_{L H a p u m p}+E_{\text {shiller }}}{\eta_{\text {rotor }} \times \eta_{A C D C}}$

The kWh consumed by the FCEV is then multiplied by the mass of hydrogen consumed by each FCEV using the following equation: 
$E_{L H 2 F C E V}=m_{H 2 F C E V} \times E_{L H 2 \text { input }}$

Where $E_{L H 2 ~ F C E V}$ is the total amount of energy consumed from the hydrogen storage if the hydrogen consumed is stored in its liquid form.

\subsubsection{Compressed Hydrogen:}

In the scenario in which the hydrogen will be compressed instead of liquefied. Therefore, the amount of specific energy consumed by hydrogen when compressed will also be analyzed. The specific energy consumed by each equipment as well as the sum of the specific energy input is shown on table 5.2:

Table 5.2: List of specific energy consumption by different equipment in the compressed hydrogen scenario.

\begin{tabular}{|c|c|c|c|c|}
\hline Process & Equipment & Parameter & Value & Unit \\
\hline Electrolysis & PEM Electrolyzer & $\overline{E_{\text {electrolysis }}}$ & 50.33 & $\mathrm{kWh} / \mathrm{kg}$ \\
\hline Compression & Compressor & $E_{\text {compressor input }}$ & 1.81 & $\mathrm{kWh} / \mathrm{kg}$ \\
\hline Pre-Chilling & Pre-Chiller & $E_{\text {chiller }}$ & 0.27 & $\mathrm{kWh} / \mathrm{kg}$ \\
\hline Energy Generation & DFIG Rotor Side & $\eta_{\text {rotor }}$ & 0.983 & \\
\hline AC to DC Conversion & ACDC Converter & $\eta_{A C D C}$ & 0.9919 & \\
\hline \multicolumn{2}{|c|}{ Total Specific Electrical Energy Input } & $E_{G H 2 \text { input }}$ & 53.81 & $\mathrm{kWh} / \mathrm{kg}$ \\
\hline
\end{tabular}

The overall compressed hydrogen input specific energy is calculated using the values from table 5.2 and the wind turbine rotor and ACDC converter efficiency obtained from section 4.1:

$E_{\text {GHz input }}=\frac{E_{\text {electrolypsis }}+E_{\text {campregssar input }}+E_{\text {chiller }}}{\eta_{\text {rotur }} \times \eta_{A C D C}}$ 
The sum of the total energy specific input $E_{L H 2}$ input is then multiplied by the mass of hydrogen consumed by each FCEV using the following equation:

$E_{G H 2 F C E V}=m_{H 2 F C E V} \times E_{G H 2 \text { input }}$

Where $E_{G H 2 F C E V}$ is the total amount of energy consumed from the hydrogen storage if the hydrogen consumed is stored in its gaseous form.

\subsection{Comparing scenarios}

For the electric cars, the range; charging time; and the energy consumption over city, highway, and combined settings will be averaged out and have standard deviation added to determine the variation between the electric cars. For the fuel cell cars, the range, the kilograms per 100 miles, and the energy consumption over city highway, and combined settings will be averaged out and have standard deviation added to determine the variation between the fuel cell cars for liquid and compressed hydrogen sub-scenarios.

The equation for the mean is the following:

$\bar{x}=\sum_{i=1}^{N} \frac{x_{i}}{N}$

$\sigma=\sqrt{\sum_{i=1}^{N} \frac{\left(x_{i}-\bar{x}\right)}{N-1}}$

Where $\bar{x}$ is the mean value of the samples, $x_{i}$ is the sample value, $N$ is the number of samples, and $\sigma$ is the standard deviation.

To compare the liquid and compressed hydrogen overall energy consumption, each hydrogen mass consumption over 100 miles by each FCEV will be multiplied. The product of each FCEV 
at each sub-scenario will be averaged from the overall electric efficiency, so it can be divided by scenario 1 overall efficiency and multiplied by 100 so the percent difference can be determined. The same procedure will be done using the average energy consumption from the battery bank. 


\section{Results and Analysis}

\subsection{Scenario 1: Electric Cars}

\section{$\underline{6.1 .1 \text { Overall Electric Efficiency }}$}

This section addresses the overall electric efficiency of the first scenario. Using equation 5.1 from section 5 and data from section 4.3. The overall electric efficiency for the electric car is:

$$
\eta_{\text {overall electric }}=\frac{98.30}{100} \times \frac{99.19}{100} \times \frac{90}{100} \times \frac{99.5}{100} \times \frac{92.59}{100} \times 100 \%=80.84 \%
$$

To calculate how many $\mathrm{kWh}$ of the wind turbine are consumed per charged $\mathrm{kWh}$ to the BEV the overall efficiency can be simply inverted:

$$
\frac{k \text { Wh consumed from wind farm }}{k \text { Wh charged to car }}=\frac{100}{80.84}=1.24 \mathrm{kWh} / \mathrm{kWh}
$$

\subsubsection{Pre-charge, range available, charging time, and energy consumption}

Four different electric cars with the greatest mile range were selected to be evaluated and the battery energy available when driven 100 miles after being $80 \%$ charged, the time taken to charge each car, and the energy consumed from the battery bank when charging the cars back to 80\% at city, highway, and combined settings: 
Table 6.1: BEV available energy before and after charging, charging time needed after running 100 miles in a combined city and highway setting.

\begin{tabular}{|c|c|c|c|c|c|c|c|}
\hline Make & Model & Year & $\begin{array}{c}\text { Battery } \\
\text { Energy } \\
(\mathrm{kWh})\end{array}$ & $\begin{array}{c}\text { Pre- } \\
\text { Charge } \\
\text { Energy } \\
(\mathrm{kWh})\end{array}$ & $\begin{array}{c}\text { Range } \\
\text { Available } \\
\text { before } \\
\text { charge }(\%)\end{array}$ & $\begin{array}{c}\text { Charging } \\
\text { Time (min) }\end{array}$ & $\begin{array}{c}\text { Total } \\
\text { Energy } \\
\text { Consumed } \\
(\mathrm{kW})\end{array}$ \\
\hline Tesla & $\mathrm{S}$ & 2020 & 100 & 50 & 50 & 36 & 37.11 \\
\hline Nissan & Leaf & 2019 & 62 & 18.6 & 30 & 37.2 & 38.35 \\
\hline Chevrolet & Bolt EV & 2020 & 66 & 22.8 & 34.55 & 36 & 37.11 \\
\hline Porsche & $\begin{array}{c}\text { Taycan } \\
\text { Turbo S }\end{array}$ & 2020 & 93.4 & 24.72 & 26.47 & 60 & 61.85 \\
\hline \multicolumn{7}{c}{ Average } & $80.35 \pm$ \\
19.14 & $\begin{array}{c}29.03 \pm \\
14.21\end{array}$ & $\begin{array}{c}35.25 \pm \\
10.37\end{array}$ & $\begin{array}{c}42.3 \pm \\
11.81\end{array}$ & $\begin{array}{c}43.6 \pm \\
12.18\end{array}$ \\
\hline
\end{tabular}

Table 6.2: BEV available energy before and after charging, charging time needed after running 100 miles in a city setting.

\begin{tabular}{|c|c|c|c|c|c|c|c|}
\hline Make & Model & Year & $\begin{array}{c}\text { Battery } \\
\text { Energy } \\
(\mathrm{kWh})\end{array}$ & $\begin{array}{c}\text { Pre- } \\
\text { Charge } \\
\text { Energy } \\
(\mathrm{kWh})\end{array}$ & $\begin{array}{c}\text { Range } \\
\text { Available } \\
\text { before } \\
\text { charge }(\%)\end{array}$ & $\begin{array}{c}\text { Charging } \\
\text { Time (min) }\end{array}$ & $\begin{array}{c}\text { Total } \\
\text { Energy } \\
\text { Consumed } \\
(\mathrm{kWh})\end{array}$ \\
\hline Tesla & $\mathrm{S}$ & 2020 & 100 & 51 & 51.00 & 38.67 & 35.87 \\
\hline Nissan & Leaf & 2019 & 62 & 20.6 & 33.23 & 38.67 & 35.87 \\
\hline Chevrolet & Bolt EV & 2020 & 66 & 26.8 & 40.61 & 34.67 & 32.16 \\
\hline Porsche & $\begin{array}{c}\text { Taycan } \\
\text { Turbo S }\end{array}$ & 2020 & 93.4 & 24.72 & 26.47 & 66.67 & 61.85 \\
\hline \multicolumn{7}{|c|}{ Average } & $80.35 \pm$ \\
19.14 & $\begin{array}{c}30.78 \pm \\
13.72\end{array}$ & $\begin{array}{c}37.82 \pm \\
10.51\end{array}$ & $44.67 \pm 14.79$ & $\begin{array}{c}41.44 \pm \\
13.72\end{array}$ \\
\hline
\end{tabular}


Table 6.3: BEV available energy before and after charging, charging time needed after running 100 miles in a highway setting.

\begin{tabular}{|c|c|c|c|c|c|c|c|}
\hline Make & Model & Year & $\begin{array}{l}\text { Battery } \\
\text { Energy } \\
(\mathrm{kWh})\end{array}$ & $\begin{array}{l}\text { Pre- } \\
\text { Charge } \\
\text { Energy } \\
(\mathrm{kWh})\end{array}$ & $\begin{array}{c}\text { Range } \\
\text { Available } \\
\text { before } \\
\text { charge }(\%)\end{array}$ & $\begin{array}{l}\text { Charging } \\
\text { Time (min) }\end{array}$ & $\begin{array}{c}\text { Total } \\
\text { Energy } \\
\text { Consumed } \\
(\mathrm{kWh})\end{array}$ \\
\hline Tesla & $\mathrm{S}$ & 2020 & 100 & 49 & 49 & 41.33 & 38.35 \\
\hline Nissan & Leaf & 2019 & 62 & 14.6 & 23.55 & 46.67 & 43.29 \\
\hline Chevrolet & Bolt EV & 2020 & 66 & 21.8 & 33.03 & 41.33 & 38.35 \\
\hline Porsche & $\begin{array}{c}\text { Taycan } \\
\text { Turbo S }\end{array}$ & 2020 & 93.40 & 25.72 & 27.54 & 65.33 & 60.61 \\
\hline \multicolumn{3}{|c|}{ Average } & $\begin{array}{c}80.35 \pm \\
19.14\end{array}$ & $\begin{array}{c}27.78 \pm \\
14.88\end{array}$ & $\begin{array}{c}33.28 \pm \\
11.19\end{array}$ & $48.67 \pm 11.39$ & $\begin{array}{c}45.15 \pm \\
10.57\end{array}$ \\
\hline
\end{tabular}

Several observations have been made when looking at the data on the tables and the graphs. The Tesla S 2020 has the greatest battery capacity with $100 \mathrm{kWh}$, followed by the Porsche Taycan S 2020 with 93.4 kWh capacity, followed by the Chevrolet Bolt EV 2020 with $66 \mathrm{kWh}$ capacity, followed by the Nissan Leaf 2019, with 62kWh capacity.

After running 100 miles on highway, city, and combined settings, the Tesla Model S has the greatest battery energy capacity available at all three settings with $50 \mathrm{kWh}$ available at combined setting, $51 \mathrm{kWh}$ at city setting, and 49kWh at highway setting. The car model that has the second largest battery energy capacity at combined and highway settings is the Porsche Taycan Turbo S with $24.72 \mathrm{kWh}$ and $25.72 \mathrm{kWh}$ respectively. The car model that has the second largest battery energy capacity available is the Chevrolet Bolt EV, $26.8 \mathrm{kWh}$ available.

The Tesla $\mathrm{S}$ model as the highest pre-charging percent battery energy capacity available at all of the three settings, with 50\% energy capacity at combined setting, 51\% energy capacity at city setting, and $49 \%$ at highway setting. The Chevrolet Bolt EV model has the second largest percent of battery energy capacity all of three settings with $34.55 \%$ at combined setting, $40.61 \%$ 
at city setting, and $33.03 \%$ at highway setting. The Nissan Leaf model has third largest battery energy capacity percentage available at combined and city settings with $30 \%$ and $33.23 \%$ respectively. The Porsche Taycan Turbo S model has the third largest energy capacity percentage available of $27.54 \%$ at highway setting. The Porsche Taycan Turbo S model, however, has the lowest battery energy capacity percentage at $26.47 \%$ at combined and city settings.

The models Tesla S and Chevrolet Bolt EV have the shortest charging time of 36 minutes and 41.33 minutes at combined and highway settings, respectively. The Chevrolet Bolt EV model has the shortest charging time, 34.67 minutes at city setting. The models Tesla $\mathrm{S}$ and Nissan Leaf have the second shortest time, 38.67 minutes at city setting. The Nissan Leaf model has third shortest charging time at combined and highway settings 41.33 and 46.67 minutes long respectively. Porsche has the longest charging time at all three settings, 66.67 minutes at combined and city settings and 65.33 minutes at highway setting.

The models Tesla S and Chevrolet Bolt EV consumed the least amount of energy from the wind turbine at all settings. The models Tesla $\mathrm{S}$ and Chevrolet Bolt EV consumed $37.11 \mathrm{kWh}$ and $38.35 \mathrm{kWh}$ at combined and highway settings respectively. At city setting, the Chevrolet Bolt EV model consumed the least amount of energy from the battery bank, $32.16 \mathrm{kWh}$ followed by Tesla S, that consumed $35.87 \mathrm{kWh}$ along with Nissan Leaf. Porsche Taycan Turbo S consumed the largest amount of energy from the battery bank at all settings, $61.85 \mathrm{kWh}$ at combined and city settings and $60.61 \mathrm{kWh}$ at highway setting.

Tables 6.1, 6.2, and 6.3 show the results obtained at combined, city, and highway respectively while figures $6.1,6.2,6.3$, and 6.4 show pre-charge battery energy capacity available, the percentage battery energy capacity available before charging, the time it takes to charge the BEVs back to $80 \%$, and the amount of energy consumed from the battery bank 
respectively at city, highway, and combined settings. The figures show that on average, energy is consumed the most on highways.

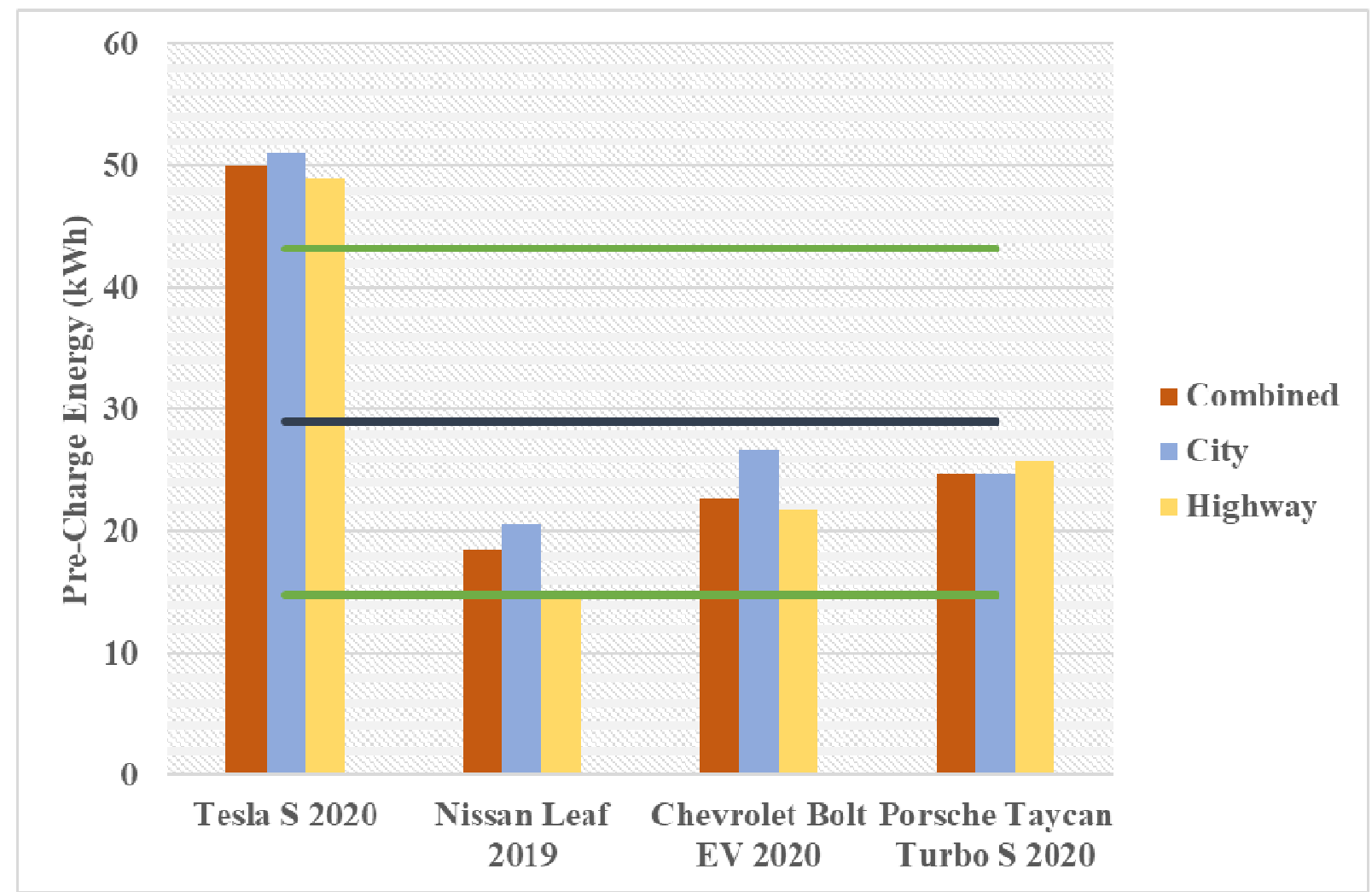

Figure 6.1: Battery energy available before charging. 


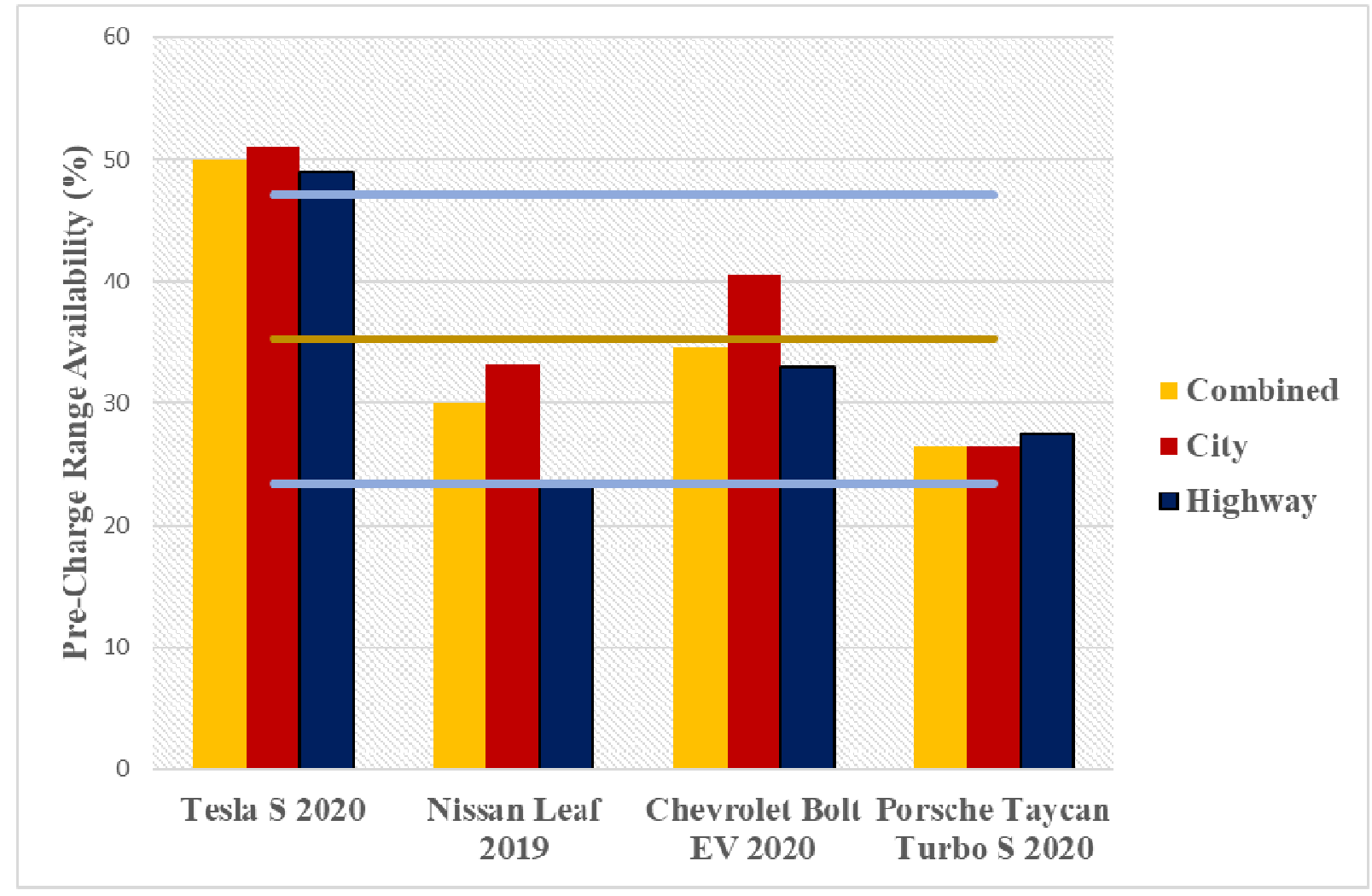

Figure 6.2: Pre-charge range availability of cars at different settings. 


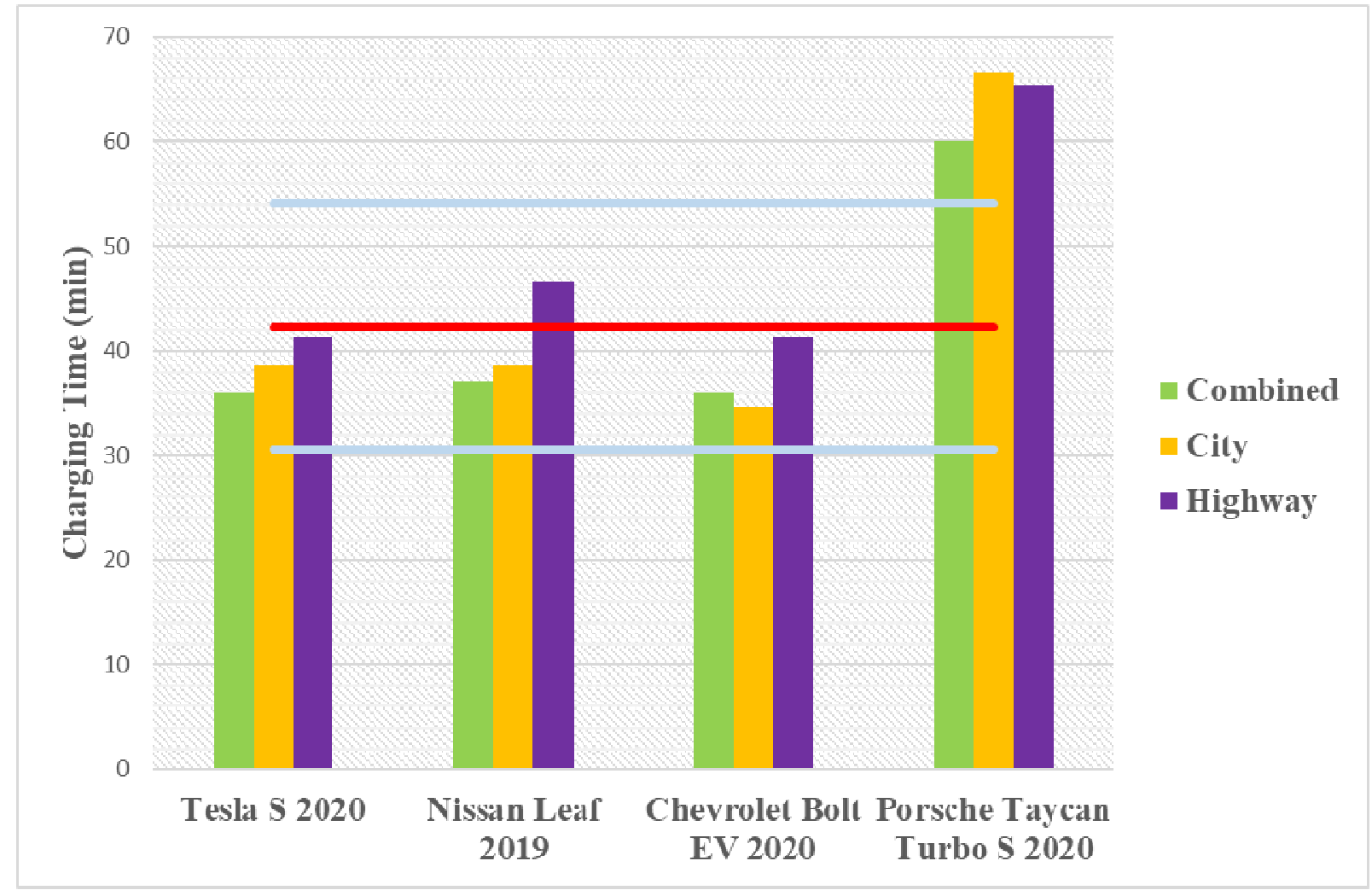

Figure 6.3: Time taken to charge the BEV back to $80 \%$. 


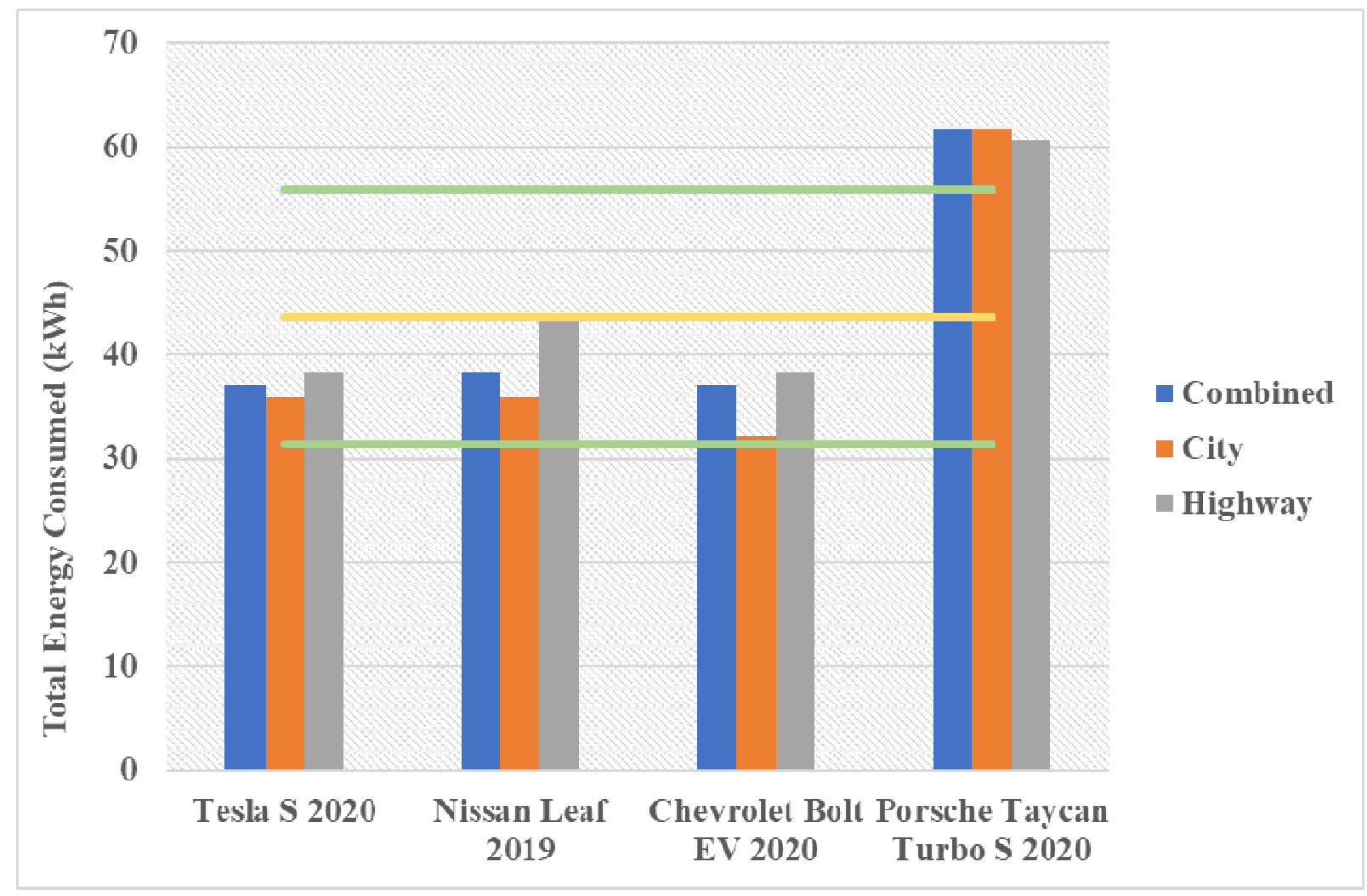

Figure 6.4: Amount of energy from the battery bank consumed to charge back to $80 \%$.

\subsection{Scenario 2: Fuel Cell Cars}

\section{$\underline{6.3 .1 \text { Energy consumed from the } \mathrm{H}_{2} \text { storage with compressed } \mathrm{H}_{2}}$}

Four different fuel cell cars were selected to have their energy consumption evaluated, by comparing the amount of energy that is consumed if the hydrogen is compressed. The amount of energy consumed by each fuel cell car is shown on table 6.4. Figure 6.5 shows the amount of energy from the hydrogen storage at the wind farm consumed by each fuel cell car over 100 miles at combined city and highway settings, city setting, and highway settings. 
Table 6.4: Scenario 2 Electrical energy consumed over 100 miles at $77^{\circ} \mathrm{F}$ ambient temperature with compressed hydrogen in $\mathrm{kWh}$.

\begin{tabular}{|c|c|c|c|c|c|}
\hline \multirow{2}{*}{ Make } & \multirow{2}{*}{ Model } & \multirow{2}{*}{ Year } & Combined & City & Highway \\
\cline { 4 - 6 } & & & \multicolumn{2}{|c|}{ Energy consumed over 100 miles (kWh) } \\
\hline Toyota & Mirai & 2019 & 81.53 & 82.78 & 81.53 \\
\hline Honda & Clarity Fuel Cell & 2020 & 81.53 & 80.31 & 81.53 \\
\hline Hyundai & Nexo Limited & 2020 & 96.08 & 92.77 & 101.52 \\
\hline Hyundai & Nexo Blue & 2020 & 89.68 & 84.07 & 96.08 \\
\hline \multicolumn{3}{|c|}{ Average } & $87.2 \pm 7.06$ & $84.98 \pm 5.42$ & $90.16+10.22$ \\
\hline
\end{tabular}

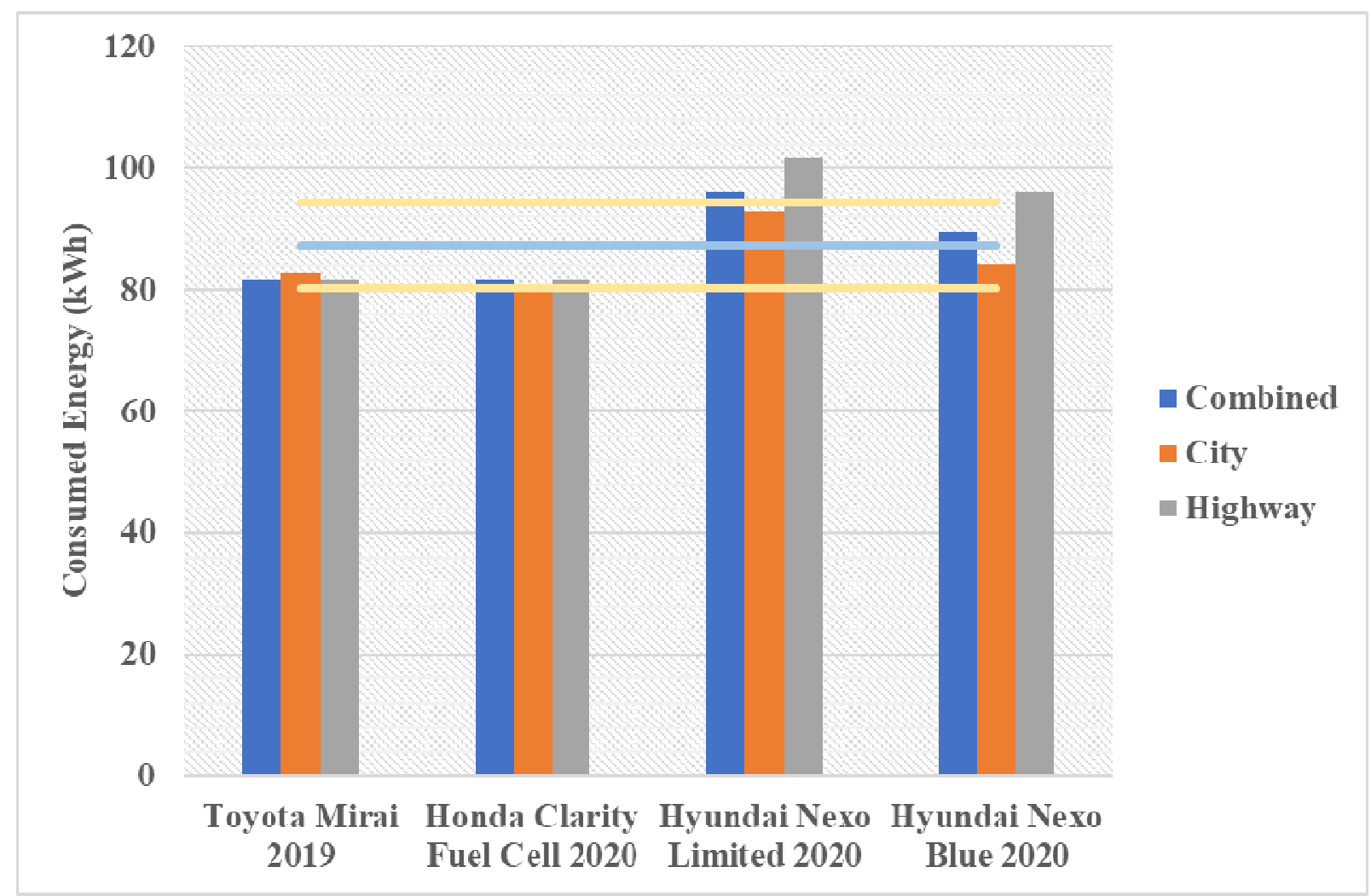

Figure 6.5: Energy consumed when compressed hydrogen is used at combined city and highway, highway, and city settings.

The FCEV that consumes the least amount of energy are Toyota Mirai and Honda Clarity, which consume $81.53 \mathrm{kWh}$ at combined and highway settings, however, Toyota Mirai consumes more energy in a city drive than in the highway, $82.78 \mathrm{kWh}$ in the city and 81.53 in the highway, while Honda Clarity consumes less in the city route, $80.31 \mathrm{kWh}$ in the city and 
$81.53 \mathrm{kWh}$ in the highway. The Hyundai Nexo Limited model consumes the highest amount of energy in all settings: $96.08 \mathrm{kWh}, 92.77 \mathrm{~kW}$, and $101.52 \mathrm{~kW}$ at combined, city, and highway respectively. With compressed hydrogen, the average consumption is $87.2 \mathrm{kWh}, 84.98 \mathrm{kWh}$, and $90.16 \mathrm{kWh}$ at combination, city, and highway settings.

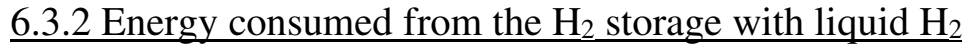

The fuel cell cars follow the same pattern in energy consumption with liquid hydrogen as with compressed hydrogen. Table 6.5 shows DFIG energy consumed by each fuel cell car when hydrogen was liquefied over 100 miles at combined city and highway, city, and highway settings. Figure 6.6 shows the energy consumption of each car at the three different settings.

Table 6.5: Amount of DFIG energy consumed by each fuel cell car with liquid hydrogen in kWh.

\begin{tabular}{|c|c|c|c|c|c|}
\hline \multirow{2}{*}{ Make } & \multirow{2}{*}{ Model } & \multirow{2}{*}{ Year } & Combined & City & Highway \\
\hline & & & \multicolumn{3}{|c|}{ Energy consumed over 100 miles $(\mathrm{kWh})$} \\
\hline Toyota & Mirai & 2019 & 103.94 & 105.54 & 103.94 \\
\hline Honda & Clarity Fuel Cell & 2020 & 103.94 & 102.39 & 103.94 \\
\hline Hyundai & Nexo Limited & 2020 & 122.5 & 118.28 & 129.43 \\
\hline Hyundai & Nexo Blue & 2020 & 114.33 & 107.19 & 122.5 \\
\hline \multicolumn{3}{|c|}{ Average } & $111.18 \pm 9$ & $108.35 \pm 6.91$ & $114.95 \pm 13.03$ \\
\hline
\end{tabular}

Toyota Mirai consumes more energy in a city drive than in the highway, $105.54 \mathrm{kWh}$ in the city, while Honda Clarity consumes less in the city, $102.39 \mathrm{kWh}$ in the city. The Hyundai Nexo Limited consumes the most amount of energy in all settings: the combined city and highway is $122.50 \mathrm{kWh}, 118.28 \mathrm{kWh}$ in the city, and $129.43 \mathrm{kWh}$ in the highway. Figure 6.6 shows DFIG energy consumed with liquefied hydrogen at combined city and highway settings, city settings, and highway settings. 


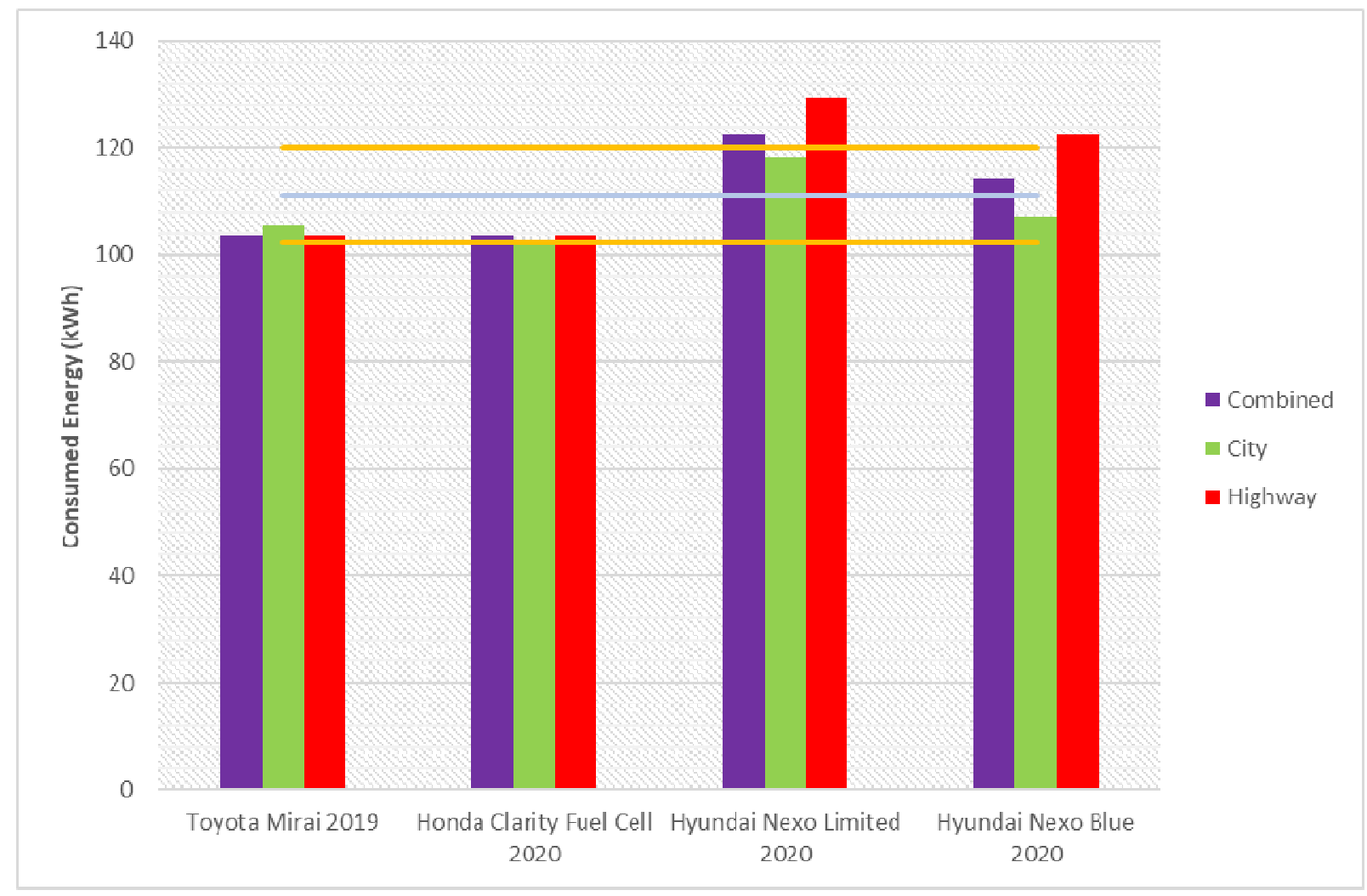

Figure 6.6: DFIG energy consumed with liquid hydrogen at combined city and highway. highway. and city settings.

\subsection{Scenarios 1 and 2: which needs more capital investment}

By evaluating the difference between the amount of energy consumed by FCEV and $\mathrm{BEV}$, it is it can be concluded that scenario $1(\mathrm{BEV})$ is more feasible than scenario 2 (FCEV). Not only FCEVs, on average, consume more energy from the DFIG than the BEVs on average, but more capital investment in scenario 2 is necessary than in scenario 1 . Table 6.6 shows that liquid hydrogen, when used to power FCEV, on average is the one that consumes energy the most, $154.98 \%$ more than BEVs, while compressed hydrogen, when used to power FCEVs consume, on average, $100 \%$ more energy than BEVs. 
Table 6.6: Difference between hydrogen fuel cell and electric vehicles energy consumption.

\begin{tabular}{|c|c|c|c|c|c|}
\hline \multirow{2}{*}{} & \multicolumn{3}{|c|}{ DFIG Consumed in kWh } & \multicolumn{2}{c|}{$\begin{array}{c}\text { Difference between BEV and } \\
\text { FCEV in (kWh) }\end{array}$} \\
\cline { 2 - 6 } & BEV & $\begin{array}{c}\text { FCEV } \\
\text { Compressed }\end{array}$ & $\begin{array}{c}\text { FCEV } \\
\text { Liquid }\end{array}$ & $\begin{array}{c}\text { FCEV } \\
\text { Compressed }\end{array}$ & $\begin{array}{c}\text { FCEV } \\
\text { Liquid }\end{array}$ \\
\hline Combined & 43.60 & 87.20 & 111.18 & 43.60 & 67.58 \\
\hline City & 41.44 & 84.98 & 108.35 & 43.55 & 66.91 \\
\hline Highway & 45.15 & 90.16 & 114.95 & 45.02 & 69.80 \\
\hline
\end{tabular}

Table 6.7: Percent difference between hydrogen fuel cell and electric vehicles energy consumption.

\begin{tabular}{|c|c|c|}
\hline \multirow{2}{*}{} & \multicolumn{2}{|c|}{ Difference (\%) } \\
\cline { 2 - 3 } & Compressed & Liquid \\
\hline Combined & 100.00 & 154.98 \\
\hline City & 105.09 & 161.47 \\
\hline Highway & 99.71 & 154.61 \\
\hline
\end{tabular}

In scenario 1, besides the wind turbine, the DFIG, and the rectifier, a giant battery composed of several cells in series and parallel, a buck converter, and at least one DC fast charging port to charge the vehicles. Whereas in scenario 2, even though there would be no need to build the giant battery since energy would be stored as hydrogen, besides the wind turbine, DFIG, and rectifier, more capital investment would be required to process the hydrogen to the dispenser. The following facilities would have to be built: at least one electrolyzis plant to produce the hydrogen gas, at least a hydrogen compressor (if hydrogen is to be compressed) or a liquefier plant and at least one liquid hydrogen pump (if hydrogen is to be liquefied), one prechiller for each hydrogen dispenser, and one or more hydrogen dispensers. 


\section{Conclusions}

The research in this thesis involved using wind energy stored in a giant battery onsite to power eight different vehicles (four BEVs and four FCEVs) over 100 miles in two different scenarios: the first scenario involved charging electric vehicles directly through DC fast charging and the second scenario involved using the wind energy stored in the battery to split water into hydrogen and oxygen through electrolysis and either compressing or liquefying the hydrogen, and pre-chill the hydrogen when filling-up fuel cell cars. For each $\mathrm{kWh}$ required to charge the battery on average, $1.24 \mathrm{kWh}(80.84 \%$ overall efficiency) was required from the wind farm battery bank. For each kilogram of compressed and liquid hydrogen required to fill a FCEV, $53.81 \mathrm{kWh}$ and $68.60 \mathrm{kWh}$ were required from the wind farm, respectively. For each 100-mile operation on a BEV operating at combined city and highway setting, $43.60 \mathrm{kWh}$ from the wind turbine was required for charging. For each 100-mile operation on a FCEV, $87.20 \mathrm{kWh}$ and $111.18 \mathrm{kWh}$ from the battery bank is required in compressed and liquid hydrogen cases, respectively, at a combined city and highway setting. Based on careful research and analysis of the results. it is evident that BEV is more viable than FCEV using compressed and liquid hydrogen, respectively. Even though FCEVs are less efficient than EV, hydrogen electrolysis could still have other industrial applications such as the production of ammonia and methanol and as fuel combustion for industrial boilers and process heaters (The Hydrogen Economy: Opportunities. Costs. Barriers. and R\&D Needs. 2004). 


\section{Vita}

Marina Miranda was born in Philadelphia, Pennsylvania, but lived in São Paulo, Brazil from ages six months to 15 years old, when she moved to Washington, DC area and lived there for four years. She attended Pennsylvania State University for four years, where she majored in Nuclear Engineering, with strong foundation in Mechanical Engineering, and graduated in 2007. Afterwards, she moved to Frederick, Maryland, where she worked as a Power Plant Simulation Engineer and where she lived for the next ten years. After which she moved to Morgantown, West Virginia in 2018, to attend West Virginia University to earn a Master of Science in Energy Systems Engineering with a concentration in green energy. In August 2020, she met all requirements for the degree and earned her MSc degree. 


\section{$\underline{\text { References }}$}

1. Wenjun, C., Yanlei, Z., Meng. Y., \& Jiahai, Y. (2017). "Optimal site selection of windsolar complementary power generation project for a large-scale plug-in charging station". Sustainability. 9(11). doi:10.3390/su9111994

2. Bellekom, S., Benders, R., Pelgrom, S., \& Moll, H. (2012). "Electric cars and wind energy: Two problems. one solution? A study to combine wind energy and electric cars in 2020 in the Netherlands". Energy. 45(1). 859-866.

3. "Solar Explained" U. S. Energy Information Administration, 2018. https://www.eia.gov/energyexplained/index.php?page=solar home

4. Bossel, Ulf. (2006). "Does Hydrogen Economy Make Sense?". Proceedings of the IEEE October 2006.

5. “U. S. Facts Explained” U. S. Energy Information Administration, 2019. https://www.eia.gov/energyexplained/?page=us_energy_home

6. "Renewable Energy Explained” U. S. Energy Information Administration, 2018. https://www.eia.gov/energyexplained/index.php?page=renewable home

7. “Pennsylvania Solar". Solar Energy Industries Association, 2020. https://www.seia.org/state-solar-policy/pennsylvania-solar

8. Roberts, Billy J. "Global Horizontal Solar Irradiance”. National Renewable Energy Laboratory, 2018. https://www.nrel.gov/gis/images/solar/solar_ghi_2018_usa_scale_01.jpg

9. "Ohio Solar". Solar Energy Industries Association, 2020. https://www.seia.org/state$\underline{\text { solar-policy/ohio-solar }}$ 
10. "West Virginia Solar". Solar Energy Industries Association, 2020. https://www.seia.org/state-solar-policy/west-virginia

11. "The Inside of a Wind Turbine". Office of Energy Efficiency and Renewable Energy, 2020. https://www.energy.gov/eere/wind/inside-wind-turbine

12. Nixon. Niki. "Timeline: The History of Wind Power". The Guardian, 2008. https://www.theguardian.com/environment/2008/oct/17/wind-power-renewable-energy

13. "Wind Explained" U. S. Energy Information Administration, 2018. https://www.eia.gov/energyexplained/index.php?page=wind history

14. "Downwind Rotor". Hitachi. Wind Turbine. Products, 2020. http://www.hitachi.com/products/energy/wind/products/htw2000_80/rotor/index.html

15. "Wind Industry Map.” American Wind Energy Association, 2019. https://www.awea.org/about-awea/partners

16. "Wind Energy in Pennsylvania." Office of Energy Efficiency and Renewable Energy, 2020. https://windexchange.energy.gov/states/pa\#capacity

17. "Wind Energy" Pennsylvania Department of Environmental Protection, 2020. https://www.dep.pa.gov/Business/Energy/Wind/Pages/default.aspx

18. "Wind Energy in Ohio.” Office of Energy Efficiency and Renewable Energy, 2019. https://windexchange.energy.gov/states/oh

19. "Wind Energy in West Virginia”. Office of Energy Efficiency and Renewable Energy, 2019. https://windexchange.energy.gov/states/wv\#capacity

20. "Renewable Energy". West Virginia Office of Energy, 2020. https://energywv.org/wvenergy-profile/renewable-energy 
21. Erjavec, Jack. (2013). Hybrid, Electric and Fuel-Cell Vehicles (2nd Edition)-Cengage Learning. Inc., Retrieved from

https://app.knovel.com/hotlink/pdf/id:kt00B90QE7/hybrid-electric-fuel/hybrid-basintroduction

22. Nel M Series. (2020). Hydrogen Generation Systems. Retrieved from: https://nelhydrogen.com/wp-content/uploads/2020/03/M-Series-Spec-Sheet-Rev-D.pdf

23. "Hydrogen Production: Electrolysis". Office of Energy Efficiency and Renewable Energy. 2019. https://www.energy.gov/eere/fuelcells/hydrogen-production-electrolysis

24. Berstad, David O., Stang, Jacob H., and Neksa, Petter. (2008). Comparison criteria for large-scale hydrogen liquefaction processes. SINTEF Energy Research. Sem Saelands vei 11. NO-7464 Trogeheim. Norway.

25. Mitsubishi Electric. (2014). High Power Switching Use Insulator Type [Datasheet]. Retrieved from http://www.mitsubishielectric-mesh.com.cn/products/pdf/CM450DXL34SA_N1.pdf

26. Burton, Tony (2011). Wind Energy Handbook. $2^{\text {nd }}$ ed. Chichester, West Sussex : Wiley, 2011. WVU Library.

27. Capehart, Barney L., Turner. Wayne C., and Kennedy, William J. "Wind Energy." Guide to Energy Management. Eighth Edition. The Fairmont Press Inc. 2016. pp 526.

28. "Mitsubishi MWT-95/2.4". https://en.wind-turbine-models.com/turbines/359-mitsubishi$\underline{\text { mwt-95-2.4 }}$

29. Project X 8760

30. Hydrogen_Delivery_Scenario_Model_Analysis_(HDSAM)_V3.1 
31. Tamura, J. (2012) Calculation Method of Losses and Efficiency of Wind Generators. In: Muyeen S. (eds) Wind Energy Conversion Systems. Green Energy and Technology. Springer. London

32. Wu, B., Lang, Y., Zargari. N., \& Kouro, S. (2011). Power conversion and control of wind energy systems (Ieee press series on power engineering). Hoboken. N.J.: Wiley. (2011). Retrieved January 31. 2020. from https://ieeexplore.ieee.org/xpl/ebooks/bookPdfWithBanner.jsp?fileName=6047595.pdf\& $\underline{\text { bkn}}=6047595 \&$ pdfType $=$ book.

33. Toshiba. (2018). IGBTs (Insular Gate Bipolar Transistors) [Brochure].

34. Julien, C., Maugan, A., Vish, A., and Zaghib, K.. "Lithium-Ion Battery”. Springer International Publishing. Switzerland. 2016. Chapters 1 and 2.

35. Lithium Ion Battery Datasheet. (2016). Lithium Ion Battery Datasheet. Retrieved from https://www.eemb.com/battery/rechargeable-battery/li-ion-battery/cylindrical-type.html

36. Rao, Norman and Chamud, Denesh. (2014). Calculating Power Losses in an IGBT Model. Retrieved from https://www.dynexsemi.com/assets/downloads/DNX_AN6156.pdf

37. Skyllas-Kazacos, M. (2010). Stand-Alone and Hybrid Wind Energy Systems Technology. Energy Storage and Applications - 10.1 Introduction. Woodhead Publishing. Retrieved from https://app.knovel.com/hotlink/pdf/id:kt0098PG11/stand-alone-hybrid-wind/electrochemical-introduction

38. Hayes, John G. and Goodarzi, G. Abas. Electric Powertrain: Energy Systems. Power Electronics and Drives for Hybrid. Electric and Fuel Cell Vehicles. John Wiley \& Sons. 
Incorporated. 2018. ProQuest Ebook Central.

https://ebookcentral.proquest.com/lib/wvu/detail.action?docID=5148928.

39. Sumper, Andreas. et al. Energy Storage in Power Systems. John Wiley \& Sons. Incorporated. 2016. ProQuest Ebook Central.

https://ebookcentral.proquest.com/lib/wvu/detail.action?docID=4443208

40. Harrison, K. W., Remick, R., and Martin, G. D.. and Hoskin. A. Hydrogen Production: Fundamentals and Case Study Summaries. Conference Paper NREL/CP-500-47302. January 2010. Retrieved from: https://www.nrel.gov/docs/fy10osti/47302.pdf

41. Valøen, Lars Ole and Shoesmith. Mark I. (2007). The effect of PHEV and HEV duty cycles on battery and battery pack performance (PDF). 2007 Plug-in Highway Electric Vehicle Conference: Proceedings. Retrieved 11 June 2010.

42. CEC Inverter Test. (2020). PV Performance Modeling Collaborative. Retrieved from: https://pvpmc.sandia.gov/modeling-steps/dc-to-ac-conversion/cec-inverter-testprotocol/\#: :text=Inverter\%20efficiency $\% 20$ is $\% 20$ the $\% 20$ ratio.voltage $\% 2 \mathrm{C} \% 20$ and $\% 20$ sometimes\%20inverter\%20temperature.

43. EV Specifications. (2020). Specifications. News. and Comparisons. Retrieved from: https://www.evspecifications.com/en/comparison/f2f51117

44. Godula-Jopek, Agata. et al. Hydrogen Storage Technologies : New Materials. Transport. and Infrastructure. John Wiley \& Sons. Incorporated. 2012. ProQuest Ebook Central. https://ebookcentral.proquest.com/lib/wvu/detail.action?docID=966171

45. Broussely, M. Pistoia. G. (2007). Industrial Applications of Batteries - From Cars to Aerospace and Energy Storage - 4.2.1 Electric Vehicles (EV). Elsevier. Retrieved from: 
https://app.knovel.com/hotlink/pdf/id:kt006N5LP6/industrial-applications/electric$\underline{\text { vehicles-ev }}$

46. 2019 Tesla Model S. (2019). https://www.motortrend.com/cars/tesla/model-s/2019/

47. The Tesla Team. (2019). The Longest-Range Electric Vehicle Now Goes Even Farther. Retrieved from: https://www.tesla.com/blog/longest-range-electric-vehicle-now-goeseven-farther

48. Learn Engineering. "How does an electric car work". YouTube. Educational Video. July $14^{\text {th }} .2020$. https://www.youtube.com/watch?v=3SAxXUIre28\&t=500s

49. Bower, George. (2015). Tesla Patent Outlines Sensible Approach to Cabin Heating. INSIDEEVs. Retrieved from: https://insideevs.com/news/328782/tesla-patent-outlinessensible-approach-to-cabin-heating/

50. Fuel Economy Guide. (2019). U.S. Department of Energy

51. 2020 Guide On How To Charge Electric Car With Charging Stations. (2020). Retrieved from: https://chargehub.com/en/electric-car-charging-guide.html\#charginglevels

52. Huggins, R.A. (2016) Hydrogen Storage. In: Energy Storage. Springer. Cham

53. "Your On-site Hydrogen Fueling Station” Specifications. 2019. https://www.pdcmachines.com/simplefuel/specifications/

54. Hydro-Pac Inc. (2011). LX Series TM Hydrogen Compressors 1500 to 12000 psi [Brochure]. Retrieved from http://www.hydropac.com/literature/LXSERIES\%20Hydrogen\%20Brochure\%2001_2011-\%20reduced.pdf

55. Transportation and Climate Change (2020). Carbon Pollution from Transportation. Retrieved from: https://www.epa.gov/transportation-air-pollution-and-climate$\underline{\text { change/carbon-pollution-transportation }}$ 
56. The Hydrogen Economy: Opportunities. Costs. Barriers. and R\&D Needs (2004). Useful Conversions and Thermodynamic Properties. Retrieved from:

https://www.nap.edu/read/10922/chapter/21

57. Elgowainy, Amgad and Reddi, Krishna (2016). Hydrogen Fueling Station Pre-Cooling Analysis. Argonne National Laboratory. 2016 DOE Hydrogen and Fuel Cell Program Annual Merit Review.

58. Gandia, Luis M., Arzamedi, Gurutze, and Dieguez, Pedro M.. (2013). Renewable Hydrogen Technologies - Production. Purification. Storage. Applications and Safety 2.1.1 Brief Historical Review. Elsevier. Retrieved from https://app.knovel.com/hotlink/pdf/id:kt00C600G4/renewable-hydrogen$\underline{\text { technologies/brief-historical-review }}$ 